Revista lus et Praxis, Año 24, No 3, 2018, pp. 693 - 762

ISSN 0717 - 2877

Universidad de Talca - Facultad de Ciencias Jurídicas y Sociales

Delitos cometidos en torno al desarrollo de los procesos electorales:

consideraciones sobre sus fundamentos y sistematización

Francisco Maldonado Fuentes

Trabajo recibido el 20 de marzo y aprobado el 23 de octubre de 2018

\title{
Delitos cometidos en torno al desarrollo de los \\ procesos electorales: consideraciones sobre sus fundamentos y sistematización
}

\author{
Offenses COMMITTED IN THE ElECTORAL PROCESSES: CONSIDERATIONS ON ITS \\ FOUNDATIONS AND SYSTEMATIZATION
}

\section{Francisco Maldonado Fuentes*}

\begin{abstract}
RESUMEN
La presente contribución busca ofrecer una panorámica sobre los principales caracteres bajo los cuales se suele configurar la regulación de los delitos asociados al desarrollo de los procesos electorales. El tratamiento se contextualiza en la alta preocupación que hoy en día detentan los actos de corrupción. Básicamente procura dar cuenta de cómo impactan dichos caracteres (asociados a una regulación amplia, heterogénea, casuística y dispersa) en su escasa aplicación y en la baja atención que doctrina y jurisprudencia les suelen brindar. Sobre esa base, se ofrece una perspectiva crítica centrada en el tratamiento del bien jurídico protegido y de su estructura de injusto, con el objeto de extraer algunas consideraciones dogmáticas y político criminales fundamentales. Entre ellas, destacan las implicancias en materia concursal y en su conceptualización como forma de corrupción.
\end{abstract}

\section{ABSTRACT}

This contribution seeks to provide an overview of the main characteristics of crimes usually associated with the development of electoral processes. The approach is based on the high concern that acts of corruption provoke. Basically the paper seeks to account for how these characteristics impact (associated with a broad, heterogeneous, casuistic and dispersed regulation) its limited application and the low importance that doctrine and jurisprudence usually provide. On this basis, we offer a critical perspective focused on the treatment of the protected legal interest and its unjust structure, in order to extract some fundamental criminal and political considerations.

\footnotetext{
* Abogado. Doctor en Derecho. Director del Centro de Estudios de Derecho Penal de la Universidad de Talca. Profesor Asociado e Investigador de la Facultad de Ciencias Jurídicas y Sociales de esa misma casa de estudios. El texto forma parte del proyecto Fondecyt $N^{0} 1150148$, financiado por Conicyt, referido a "Corrupción y actividad empresarial. Análisis conceptual para una nueva regulación", del cual el autor es co-investigador. El autor agradece a los Profs. Héctor Hernández B. y Fernando Londoño M. por la invitación a presentar una versión preliminar del trabajo en el marco del Coloquio de Derecho penal económico que se organiza en la Facultad de Derecho de la Universidad Diego Portales, como también las opiniones y comentarios recibidos en dicha sesión (celebrada el 13 de septiembre de 2017).
} 
Among them, the implications in concurrent offences matters and in their conceptualization as a form of corruption, stand out.

\section{Palabras Clave}

Delitos electorales, corrupción electoral, fraude electoral

KEY WORDS

Electoral crimes, electoral corruption, electoral fraud

\section{Introducción}

El fenómeno de la corrupción ocupa hoy en día un lugar preferente en la preocupaciones sociales y ciudadanas a nivel global. Las razones parecen más o menos evidentes ${ }^{1}$, y van más allá de los efectos y riesgos a los que se lo asocia su ocurrencia de forma natural ${ }^{2}$. La constatación permanente, periódica y cada vez más frecuente, de una diversidad de casos configurados a partir de conductas orientadas a la obtención o dación de prebendas o ventajas indebidas asociadas al ejercicio abusivo o a la instrumentalización de posiciones de poder, motiva un profundo descrédito y desconfianza sobre el funcionamiento de las instituciones y estructuras a través de las cuales se desarrollan las más diversas relaciones sociales, afectando además la imagen de quienes las dirigen u operan en ellas.

Si bien se trata de conductas presentes en todos los ámbitos o sectores de desarrollo de la vida social ${ }^{3}$, parece evidente que los efectos de este fenómeno se hacen sentir con más fuerza en el ámbito del quehacer público en atención a la naturaleza de sus objetivos propios, teniendo en cuenta que la calificación de la corrupción se estructura a partir de la idea de desviación del poder ${ }^{4}$. Por ello, no debe extrañar que en la actualidad la ciudadanía crea que el ejercicio de las funciones asociadas a la satisfacción de los intereses públicos se encuentra plagada de comportamientos completamente alejados

\footnotetext{
1 Para una síntesis se puede consultar VILLORIA (2006), pp. 72-93.

2 Por todos, Malem (2000), pp. 27-31; Reheren (2016), pp. 136 y 137. Entre ellos destaca la constatación de una profunda desconfianza y apatía en torno al sistema político y respecto al funcionamiento de las instituciones representativas y su incidencia en la confianza que requiere el funcionamiento de la organización social de cualquier Estado. Al respecto, MENDILOW (2012), p. 8. Destaca asimismo su incidencia en las ("Ilamadas") crisis en la economía de los diversos Estados. Al respecto, Dopico (2015), pp. 258 y 259 (con abundantes referencias de respaldo en nota $N^{\circ} 2$ ).

3 Es un hecho asentado el reconocimiento de que los actos de corrupción se pueden presentar en el quehacer público como en el ámbito privado. Contreras (2004), p. 371.

${ }^{4}$ De ahí que el contenido que se asocia a dicha calificación ("corrupción"), se vincule a efectos de carácter "corrosivo" (coincidente con la percepción coloquial de su significado), en cuanto se trata de conductas que "erosionan" las estructuras institucionales a través de las cuales se configura el ejercicio del poder estatal. Al respecto véase Álvarez (2007), pp. 40 y 41.
} 
de sus objetivos propios (el servicio del bien colectivo o común), asentándose la imagen de que las grandes decisiones que impactan en la vida de los ciudadanos y personas comunes, son realmente adoptadas a través de los políticos por quienes detentan o concentran el poder social y económico (los poderosos), a favor de la protección de sus intereses, y con perjuicio del interés general y del rol que a dichos efectos cumple su administración en base a la representación popular ${ }^{5}$. Por ello, subyace a este fenómeno la idea de que la relación entre dinero y política se resuelve de manera irregular en la amplia mayoría de los casos relevantes ${ }^{6}$, motivando un profundo desprestigio en la actividad de quienes se dedican a la administración del poder representativo y una desafección en la ciudadanía?.

Si bien no es posible obviar que este tipo de comportamientos han acompañado a la humanidad desde siempre y que su ocurrencia parece inherente a la organización social ${ }^{8}$, las dimensiones que ha cobrado en la actualidad

\footnotetext{
${ }^{5}$ Con ello, el debilitamiento de las estructuras democráticas se vincula al hecho de que genera oportunidades de acceso diferentes que perjudican a la mayoría para beneficio de una minoría, contribuyendo a la "desigualdad". En este sentido Álvarez (2007), p. 51. De esta forma se vincula la idea de "corrupción" con la obtención de un beneficio indebido (BALMACEDA y CASTRO (2015), p. 55) y con la idea de "deslealtad" (Malem (2007), p. 173) a partir de la advertencia de una contraposición entre el interés del agente y el interés público (CONTRERAS (2004), p. 390).

${ }^{6}$ Por ello se sostiene que en estos casos "la frontera entre lo público y lo privado aparece esencialmente desdibujada" (CONTRERAS (2004), p. 373). A este respecto resulta preciso hacer referencia a lo señalado por Olaizola cuando sostiene que: "Estoy de acuerdo con Ferrajoli cuando afirma que la separación entre la esfera pública y la privada es mucho más importante que la separación entre los tres poderes del Estado y no está escrita en ninguna parte porque forma parte del constitucionalismo profundo de toda democracia. Dicha separación supone la eliminación de la confusión entre soberanía y propiedad (...). La corrupción hace que los sectores económicos sean los que impongan los reales programas políticos, aunque no se publiciten" (Olaizola (2015), p. 184). Hay que tener en cuenta, sin embargo, que la relación entre política y dinero es lógica y, además, razonable (ambas se necesitan mutuamente para sus objetivos propios), de forma que es sensato concluir que deben gozar de un espacio legítimo de interacción. Al respecto, contundente, MALEM (2000), p. 26.
}

7 Doval (2014), p. 41. Al respecto véase también Malem (2007), p. 174; Reheren (2016), p. 136; Olaizola (2015), pp. 184 y 185; CONTRERAS (2004), p. 385; asimismo ver BALMACEDA y CASTRO (2015), pp. 57-69. El fenómeno se identifica en la literatura con la idea de "crisis de representación" y se le reconoce carácter generalizado en las democracias contemporáneas. Al respecto ReHEREN (2016), p. 132.

${ }^{8}$ En lo referente a nuestro objeto de estudio (la corrupción electoral) esto es claro. La historia ofrece ejemplos que ponen en evidencia que, desde siempre, se ha pretendido alcanzar el poder de forma irregular o para la satisfacción de intereses individuales, ganancias o prebendas irregulares. Al respecto véase De Urbano (2011), p. 1; Patiño (2012), p. 27; Cruz Blanca (2013), p. 6; García (2016), p. 116; Peñaranda (1986), p. 1218 (destacando los casos de compra de votos o presión de parte de quienes ejercen una posición de autoridad); Contreras (2004), pp. 374 y 375; Malem (2007), p. 171; Malem (2000), p. 34. En torno al Chile republicano, CAMACHo (2015), p. 118. Con respecto a Grecia y Roma véase Galeano (2011), pp. 538 y ss. 
parecen inéditas ${ }^{9}$ y han motivado reacciones colectivas y ciudadanas que dan cuenta de niveles de intolerancia que hasta ahora eran desconocidos ${ }^{10}$. En concreto, se han multiplicado exponencialmente los casos judiciales asociados a dicho fenómeno y además sus efectos han sido calificados como altamente nocivos pues han provocado la caída de gobiernos en ejercicio, impedido la organización de otros, forzado a la pérdida de escaños y cargos de alta jerarquía y, sobre todo, motivado el nacimiento de grupos, movimientos y expresiones políticas - con niveles de representatividad no despreciables-que se estructuran a partir del escepticismo ${ }^{11}$, renegando incluso de su propia pertenencia a la clase política y sus nexos con los partidos y corrientes políticas tradicionales ${ }^{12}$. De hecho, se los suele calificar por esta razón como efectos o expresiones de carácter ciudadano, en cuanto se autodefinen al margen de las formas institucionales tradicionales de organización de la actividad política. No es por ello extraño que quienes se dedican a su ejercicio en los contextos más habituales se muestren seriamente amenazados por dichos fenómenos -tanto en forma personal y también como colectivo- ocupándose de manera prioritaria de promover amplias y profundas reformas a las estructuras y procedimientos que organizan las relaciones de poder en la sociedad, en términos que actualmente se hacen extensivos a buena parte de la actividad política y pública en general ${ }^{13}$. De esta forma, las últimas décadas han sido testigos de amplias dinámicas orientadas a la reformulación de los procesos institucionales o formales referidos a la forma como se debe desarrollar la propia actuación de los agentes públicos; de aquellos que los afectan o vinculan con operadores privados o de mercado; de aquellos que regulan el

\footnotetext{
9 Se puede apreciar con nitidez tras el desarrollo propuesto por MAROTO (2015b), pp. 85-109, referido específicamente al financiamiento irregular de la política en España.

10 Sobre algunas de las causas que pudiesen contribuir a explicar el fenómeno en el campo de la competencia política (estrechamente vinculado a los procesos electorales), véase MendiLow (2012), pp. 9 y ss. Asimismo Ortega (2016), p. 61.

11 Al respecto García (2016), p. 113.

12 Bolx (2014), p. 162, con respecto a la realidad española (en particular a propósito del financiamiento irregular de la política). Asimismo, Luzón (2015), pp. 238-240. Sobre financiamiento de partidos políticos véanse los ejemplos citados en Balmaceda y CASTRO (2015), pp. 39-44.

13 Al respecto véase De LA MATA (2016), p. 5. Sobre cómo esta preocupación también ha influido en movimientos, organismos e instrumentos de carácter internacional, véase CONTRERAS (2004), pp. 385 y 386 (con cita de instrumentos de referencia propios de la época de la obra). Asimismo, BaLmaceda y Castro (2015), pp. 74-111. Sobre el caso chileno véase García e Illanes (2007), pp. 66 y ss.
} 
funcionamiento de los partidos políticos y su financiamiento, y, en particular, la regularidad de los procesos electorales ${ }^{14}$.

El objetivo en todos los casos apunta a favorecer condiciones para un ejercicio de las funciones públicas acorde a sus fines propios, incorporándose para ello medidas y herramientas orientadas fundamentalmente a controlar y prevenir actuaciones irregulares o directamente corruptas. El grueso de las opiniones a este respecto aconseja confiar en los recursos que ofrece la trasparencia o publicidad de los procesos y de la información ${ }^{15}$ y en la promoción de condiciones que permitan contar con una mayor igualdad en el acceso a las actividades públicas, políticas y representativas en general, en reemplazo de las estructuras tradicionales centradas en las formas y en la ritualidad procedimental. Como es obvio a estas alturas $-y$ al margen de su menor utilidad, eficacia o rendimiento preventivo ${ }^{16}$ - destaca también la previsión de un fuerte régimen de sanciones orientadas a su represión (a veces muy enérgicas), concentradas preferentemente en torno a herramientas e instancias de carácter administrativo, donde resalta el recurso a elevadas multas e inhabilitaciones ${ }^{17}$. Dicho panorama se complementa -como es usual en la actualidad-con los recursos que ofrece el derecho penal, sea mediante la revisión y reformulación de los ilícitos tradicionalmente destinados a dicho fenómeno -en particular, en torno a los llamados "delitos funcionarios" - como a través de la creación de nuevas formas de comportamiento delictivo.

Detenidos en este punto -que es el que nos interesa en particular-cabe consignar que en los procesos de análisis o revisión de los recursos sancionatorios dispuestos en la regulación los legisladores han manifestado en el último tiempo una clara preferencia por la intensificación y ampliación de los casos

\footnotetext{
${ }^{14}$ Con respecto a España, Borx (2014), pp. 162, 163 y 181 y ss. (sobre el financiamiento de partidos políticos). Asimismo, véase Dopico (2015), p. 259. Una visión crítica en PALDA (1999), pp. 216 y 217 (en particular, pues entiende que no se cumple el objetivo de fondo al dificultar la aparición de nuevas o pequeñas expresiones, opiniones o movimientos).

15 ROMERO (2005), p. 112, quien incluso la califica como una medida político criminal. En el mismo sentido, constatándolo en torno a algunos procesos de reforma ocurridos en España, Borx (2014), p. 181 y en pp. 183-191 (donde se pueden consultar ejemplos asociados al financiamiento de partidos políticos incorporados en las últimas reformas sobre la materia). Respecto a Chile, véase el Informe Final. Consejo Asesor Presidencial contra los conflictos de interés, el tráfico de influencias y La CORRupCIÓN (2015), pp. 47 y 70. Sobre las ventajas de este tipo de mecanismos como forma de "combate" de prácticas corruptas véase GUICHOT (2014), pp. 217-219. Sobre las ventajas asociadas véase GARCíA (2007a), p. 24 (destacando el efecto que aportan las redes sociales); Del Castillo (1993), pp. 61-63; García (2007b), pp. 82 y ss.

${ }^{16}$ Sobre la necesidad de considerar herramientas preventivas y represivas que exceden con mucho el campo propio del Derecho Penal, véase De la Mata (2016), p. 4.

17 Gálvez y Rubio (2007), p. 110.
} 
sujetos a calificación penal ${ }^{18}$. Dicha preferencia pareciera orientada fundamentalmente por la necesidad de dar cuenta, cuando menos en forma simbólica ${ }^{19}$, de las particularidades o de la gravedad que demanda en la actualidad su consideración (a la cual ya hemos hecho referencia) ${ }^{20}$, evidenciando además una clara muestra de intolerancia y condena moral. Con ello, las bondades preventivas que el derecho administrativo sancionador ofrece en este ámbito en particular -reconocidas predominantemente en la literatura política y jurídica ${ }^{21}$ - suelen verse superadas tras la previsión de un amplio campo de figuras punibles. Pero además, es usual que el resultado de dichos procesos decante en regulaciones penales que carecen de sistematicidad, estructurándose a partir de definiciones que a veces resultan reiterativas, dispersas, muchas veces condicionadas por la contingencia y que no siempre se hacen cargo de los comportamientos de mayor incidencia o más relevantes de proscribir ${ }^{22}$. La permanente reformulación de la regulación penal -el dinamismo legislativo ${ }^{23}$ unido a la importancia que se atribuye al fenómeno en la actualidad, también parecieran haber impactado en el desarrollo de la doctrina penal, motivando

\footnotetext{
18 Dopico (2015), p. 259.
}

19 Díaz y García Conlledo (2007), pp. 143, 144 y 169, con ejemplos específicos tomados desde la década de los 90 en pp. 144 y ss. Asimismo Luzón (2015), pp. 240 y 241. Respecto al financiamiento de la política, véase Maroto (2015b), p. 170.

${ }^{20}$ A este respecto hay que tener en cuenta que la ejecución de actos referidos a procesos electorales asociados a la idea de corrupción, suele ser captada en la legislación penal común al menos en parte de los actos que comprende su ejecución. Así, es usual detectar la aplicabilidad de ilícitos asociados a falsedades, fraudes, adulteraciones contables o tributarias (además de las figuras tradicionales referidas al fraude fiscal, malversación, tráfico de influencias, negociación incompatible y cohecho). El punto radica en que muchas veces dicha tipología resulta insuficiente para expresar el sentido de gravedad específico que detenta dicha ejecución en cuanto "acto corrupto", siendo dicho interés el que motiva su tipificación autónoma, específica e independiente en estos procesos, lo que refuerza el sentido simbólico de dicho acto legislativo (al margen de las incidencias en cuanto a penalidad).

21 Al respecto véase Galeano (2011), p. 550; Boix (2014), p. 165, y De La Mata (2016), p. 22. Se destaca, en general, que el sistema penal no resulta idóneo para incidir y controlar este tipo de actos por la lentitud del proceso y la naturaleza de las formas o medios propios de reaccionar (MuÑOz (2013), p. 29) y el que la regulación penal genera en este campo ciertos efectos perversos asociados a su carácter selectivo, en tanto ofrece una especie de "apariencia de legitimidad" en las conductas infraccionales que carecen del estigma propio de la tipificación penal. Al respecto véase el interesante análisis propuesto en MAROTO (2015a), p. 758.

22 Sobre esa base DÍAz y García (2007), p. 166, sostiene que son mayores los problemas que estas regulaciones crean, que los que resuelven.

${ }^{23}$ Sobre este aspecto tratado como característico de este grupo de delitos véase PeÑaRANDA (1986), p. 1127. Pueden consultarse ejemplos específicos de la legislación española en De LA MATA (2016), pp. 20 y 21. Sobre la evolución de dicha reglamentación en el caso chileno ("grosso modo") véase García (2007a), p. 23. 
un renovado interés por el tratamiento de las problemáticas que ofrecen las correspondientes figuras penales y el contexto sobre el que inciden. Lo propio sucede con el desarrollo jurisprudencial, condicionado evidentemente por la explosiva presencia de casos sometidos al conocimiento de los tribunales de justicia, y en los que aparecen involucrados -aleatoriamente-funcionarios, figuras destacables de la arena política y connotados empresarios ${ }^{24}$.

En este contexto, no deja de Ilamar la atención el caso que ofrecen los Ilamados delitos electorales, pues se trata de una constelación de figuras que detenta particularidades casi inexplicables en el contexto recién reseñado. En síntesis, constituye un conjunto de delitos que participa de todos y cada uno de los caracteres antedichos, que ha sido frecuente y periódicamente visitado por el legislador penal -modificado y, en especial, ampliado- y que a pesar de ello carece por completo de correlato efectivo, rendimiento o utilidad en todos los planos posibles de imaginar. Basta advertir que las condenas son absolutamente escasas y los procesos casi inexistentes y aleatorios ${ }^{25}$, encontrándose en general referidos a hitos o conductas marginales, de baja trascendencia o poco relevantes ${ }^{26}$.

Si bien lo dicho podrían encontrar razones explicativas sencillas tras la advertencia de una escasa taza de ocurrencia de los supuestos incriminados en dichos títulos, los antecedentes de que se dispone parecen indicar lo contrario. Primero, pues las evaluaciones de la realidad criminológica a la que se relacionan -ampliamente abordadas por la ciencia política y la sociología política- refuerzan la plena vigencia y relevancia de conductas irregulares en este ámbito ${ }^{27}$. Y segundo, pues dicha conclusión no parece compatible con la

${ }^{24}$ Sobre el caso español véase Ariño (2009), pp. 5 a 9 y 15 y ss. y Maroto (2015b), pp. 21-109, cuya relación da cuenta de numerosos casos relevantes. Sobre la realidad europea de las décadas precedentes véase, sintéticamente, BLANCO (1995), pp. 166 y ss., y 193 y ss. (especialmente en, nota Nº 81). Sobre el caso chileno da cuenta grosso modo el Informe Final, Consejo Asesor Presidencial contra los CONFLICTOS DE INTERÉS, EL TRÁFICO DE INFLUENCIAS Y LA CORRUPCIÓN (2015), p. 26.

${ }^{25}$ Cruz (2013), p. 7; Muñoz (1983), pp. 464 y 465; Galeano (2011), p. 550; RodríGuez (2006), p. 2. Otra opinión en FARALDO (2014), p. 160. Con respecto a la realidad mexicana, Espín (1997), pp. 124 y ss.

26 Sobre el sistema español en general véase Olaizola (2014), p. 178 y, en especial -en lo referido al financiamiento electoral y de campañas políticas- ROMERo (2005), p. 185. Sobre el sistema chileno daremos cuenta más adelante en el texto con algo más de detalle.

27 Como indica LehoucQ (2007), p. 18, "Estas consideraciones generales indican que el fraude electoral es común y corriente en los más diversos sistemas políticos". Hay que tener en cuenta en todo caso que los estudios empíricos no abundan, lo que especialmente se atribuye al carácter generalmente clandestino de su ejecución (LeHOuCQ (2007), p. 2) y a la fuerte incidencia que tienen factores subjetivos en las denuncias, motivadas, generalmente, por quienes no han obtenido los resultados que esperaban en los procesos eleccionarios. Asimismo, LeHoucQ (2007), p. 28. De ahí que se destaque la importancia de aproximaciones basadas en encuestas para su descripción. Al 
permanente atención y preocupación evidenciada por las autoridades políticas y por el propio legislador, especialmente en su disposición formal y periódica a renovar y ampliar su tratamiento ${ }^{28}$. Se trata por lo demás de conductas cuyas ocurrencias aparecen habitualmente constatadas a través de la historia y que han recibido desde siempre una especial atención de parte del legislador penal ${ }^{29}$. Pareciera más bien que es escaso el interés en su persecución y sanción y que es el propio sistema político y social el que tiende a evitar la atribución de responsabilidades a través de un proceso y la respectiva condena por razones de diversa índole, que en su amplia mayoría exceden el plano jurídico (incluyendo referencias a necesidades de estabilidad relativas al momento político $)^{30}$. También contribuye el hecho de que el castigo público que el votante expresa sobre este tipo de actos de corrupción suele ser relativo, pues se encuentra ampliamente documentado que muchos de ellos materializan prácticas que reciben elevados niveles de tolerancia ${ }^{31}$.

Por sobre ello pareciera además que la propia regulación positiva aporta condicionantes y características adicionales que no solo confirman dicha tendencia -tanto como el origen de sus motivaciones- sino que resultan funcionales

respecto, también LeHOucQ (2007), pp. 4 y 5. Se puede consultar un listado de estudios descriptivos de carácter etnográfico referidos a múltiples latitudes en LeHOUCQ (2007), pp. 5-14.

28 JIMÉNEZ (1994), p. 24, destaca que la percepción generalizada es que el conjunto de delitos previstos para este tipo de conductas resulta insuficiente a pesar de que la amplitud de conductas incriminadas.

29 En este sentido PeÑaranda (1986), p. 1220, quien pone de relieve que la amplitud y dispersión de conductas asociadas al cohecho electoral en general evidencia prácticas más o menos asentadas $-y$ desde antiguo- para imponer el poder en las urnas.

30 Sobre el cómo las medidas adoptadas -en general- dan cuenta de soluciones de compromiso, véase Mendilow (2012), p. 10. Asimismo, véase Malem (2007), p. 175. Sobre la falta de interés real de la propia clase política, véase Ríos (2012), p. 109; Nieva (2013), p. 3. Hay que tener en cuenta además que la literatura destaca como una característica estable el que los regímenes democráticos se encuentran acostumbrados a convivir habitualmente con niveles estructurales de corrupción. A este respecto véase MuÑoz (2013), p. 23.

31 La literatura destaca cómo ciertos fenómenos asociados a la idea de corrupción, son virtualmente tolerados por la sociedad en planos que exceden el campo propio de los procesos electorales (GALEANO (2011), p. 550). Así, por ejemplo, sucede con los casos en que los actos de corrupción aparecen vinculados a proyectos de desarrollo económico que se orientan en beneficio de la comunidad (como la realización de urbanizaciones ilegales), a diferencia de los casos asociados a la apropiación indebida de fondos públicos. La idea de base es que se perdona a quien "roba pero hace". También inciden las Ilamadas "gafas partidistas", esto es, el sesgo de la percepción que incide en que el votante reaccione diverso si el agente corrupto pertenece o no a las filas que apoya. Finalmente, si no existe una alternativa válida a la que apoyar, el votante suele preferir a quien aparece como única opción, con independencia de que se pueda ver comprometida en actos de corrupción. Respecto a todo ello, véase MuÑoz (2013), pp. 23-27 y también Nieva (2013), pp. 3 y 4. 
a dicho resultado ${ }^{32}$. Entre ellas destaca la previsión formal o la tolerancia al mero uso -más o menos fundado- de institutos o herramientas que favorecen la estabilización de las relaciones jurídicas con perjuicio del ejercicio efectivo de las responsabilidades comprometidas. Así, es usual encontrar en torno a este ámbito reglas que establecen breves plazos de prescripción respecto a las responsabilidades comprometidas, otras que regulan el ejercicio acotado o controlado de la acción penal mediante convenientes filtros y el recurso a procesos generalizados de amnistía ${ }^{33} \mathrm{o}$ indulto ${ }^{34}$. Pero también se constata esta misma funcionalidad en el simple hecho de que este grupo de delitos presenta una fisonomía particular, en tanto se configura en base a un conjunto de figuras marcadamente heterogéneas, previstas en base a fórmulas generalmente casuísticas $^{35}$ y poco relevantes (centradas en hitos o conductas que muchas veces resultan marginales ${ }^{36}$ ), que además se distribuyen en forma aleatoria a través del texto de diversos cuerpos legales de naturaleza extra penal ${ }^{37}$, siendo por ello difíciles de identificar en la generalidad de los casos.

Así sucede tanto en nuestro país como en la amplia mayoría de las regulaciones comparadas, constituyendo, de forma característica, un conjunto disperso, inorgánico y farragoso de conductas incriminadas, difícil de interpretar y aplicar, que carece -por lo mismo- de una sistemática explícita o evidente y que

32 Véase al respecto, si bien en un ámbito diverso, el desarrollo que propone Dopico (2015), pp. 273-277.

${ }^{33}$ En Chile, por ejemplo, la prescripción se regula sujeta a plazos excepcionalmente breves. Tratándose de los delitos previstos a nivel general en la Ley $\mathrm{N}^{\circ} 18.700$, el plazo previsto alcanza solo a un año (art. $153 \mathrm{~A}$ ) y, tratándose de los delitos asociados al financiamiento electoral (y de partidos políticos), el inciso segundo del art. 54 de la Ley № 19.884 prevé un plazo que se extiende a los 2 años (cualquiera sea la pena aplicable). Por su parte, se establece un régimen de acción penal mixto (régimen público previa instancia de parte calificada) en relación a los delitos asociados al financiamiento electoral (art. 27 quáter de la Ley $N^{\circ} 19.884$, introducido recientemente por la Ley № 20.900).

${ }^{34}$ Con respecto al uso de este tipo de instrumentos a nivel general (respecto de casos que se califican como actos de corrupción) véase Doval (2014), pp. 43, y 48 a 60; NieVA (2013), pp. 18 y ss. Asimismo, De la Mata (2016), p. 21. En este mismo sentido Dopico (2015), p. 260, da cuenta de una tendencia opuesta en tiempos recientes, considerando las últimas reformas propuestas en España, con desarrollo en pp. 277 y 278.

35 Por todos, Jiménez (1994), p. 24; Peñaranda (1986), p. 1127; Altes (1999), p. 172; De Urbano (2011), p. 2; Rodríguez (2006), p. 2 y, con detalle, en p. 10. Asimismo, RodríGuez, p. 1239.

36 MARTí y MUÑOz (2008), p. 1; ORTS (1977), p. 286. Unido al casuismo se argumenta infracción al principio de última ratio. Otra opinión en RodríGuez (2006), p. 2, quien justifica ambas características bajo el entendido de que los procesos electorales se deben proteger al máximo en atención a su función.

37 Constituye una tradición histórica (JIMÉNEZ (1994), p. 3) que solo reconoce excepciones aisladas de carácter histórico (p.ej., en la escueta y aislada regulación codificada propuesta en el Código Penal Español de 1848). A este respecto véase Altes (1999), p. 165; De Urbano (2011), p. 2. 
propone serias dudas respecto a las razones y criterios de base que justifican su consagración ${ }^{38}$. Esta fisonomía contribuye decisivamente a obstaculizar su uso, en tanto favorece lecturas aisladas cuyos contenidos resultan problemáticos en sus efectos globales -en términos que no hacen más que profundizar la incertidumbre- ${ }^{39}$ y por cuanto propone serias dudas sobre la razonabilidad y justificación de su aplicación ${ }^{40}$. Con ello se fortalece aún más la impresión de que la voluntad legislativa se configura en estos casos en torno a procesos legislativos poco reflexivos, que obedece a razones de conveniencia o mera contingencia que decantan en una regulación que solo responde a necesidades

\footnotetext{
38 Próximo, Rodríguez (1995), p. 1239 y Peñaranda (1986), p. 1127.

${ }^{39}$ Veremos que en este ámbito es habitual que la doctrina ofrezca aproximaciones estructuradas al margen de cualquier tipo de contexto o sistematización, aportando razones, interpretaciones y propuestas que carecen de la perspectiva que aporta el análisis comparativo o la consideración de los nexos que presentan los diversos comportamientos incriminados. Los principales (d)efectos de esta forma de proceder se hacen presente a la hora de identificar y precisar el bien jurídico protegido en este conjunto de delitos; en la propia posibilidad de identificar un único referente en común a dichos efectos (si se trata de uno o varios bienes jurídicos y, en su caso, cuáles); en la determinación de la estructura de injusto de las diversas figuras y, consecuentemente, en la determinación e interpretación concreta que cabe asignar a los correspondientes elementos que las integran.
}

40 A nivel general, es un hecho que el uso de una formula regulativa de carácter casuístico constituye una fuente inagotable de problemas por ofrecer efectos que se muestran incoherentes. A nivel particular, se advierte un riesgo cierto de desproporción, pues se trata de una técnica que favorece la sanción de conductas que, en términos de merecimiento de pena, resultan plenamente equivalentes a otras que no reciben pena o que reciben una muy diversa (más o menos gravosa). De hecho, se suele criticar como técnica regulativa por tratarse de una modalidad que favorece lagunas de punibilidad. Al respecto, Peñaranda (1986), pp. 1151-1153, quien se refiere a ello a propósito del tratamiento de estos delitos en particular, con ejemplos concretos que resultan particularmente atingentes. Se advierte asimismo una exagerada concentración en la proscripción de comportamientos individuales que resultan marginales, poco relevantes o escasamente lesivos, en especial si se los valora en función de su incidencia en los resultados del proceso electoral, tendencia que contrasta sensiblemente con la sorprendente ausencia de delitos destinados a proscribir las conductas que ofrecen una mayor potencialidad de incidencia o, cuando menos, la previsión de reglas orientadas a su consideración. Con ello, cobra fuerza la idea de que las decisiones legislativas que las motivan no se justifican, resultan exageradas (desproporcionadas), inadecuadas o innecesarias, generando una imagen que respalda la idea de que la aplicación efectiva de las correspondientes sanciones constituye algo poco sensato e injusto. Sobre esa base, la doctrina suele favorecer márgenes de impunidad, recurriendo a elementos de carácter complementarios - extratípicos- orientados a aportar razones adicionales para fundar la incriminación, orientados a alcanzar una mayor concreción en los riesgos comprometidos o a la acreditación de algún grado de conexión con los intereses que se identifican como referentes de protección. Por otro lado, se señala que esta técnica también dificulta el uso y rendimiento del método comparado por cuanto las diferencias de las tipologías impedirán la constatación de aspectos contrastables (en este sentido, JIMÉNEZ (1994), p. 24, en referencia particular a los Ilamados delitos electorales). No obstante, creemos que esta última objeción se debe asumir con reservas pues, a pesar del casuismo y la heterogeneidad, en la amplia mayoría de las regulaciones se proponen contenidos relativamente equivalentes que se diferencian solo en matices que resultan esperables. En este sentido FernándeZ y OJesto (2007), p. 1029. 
políticas de carácter coyuntural, y que no da cuenta, por exceso y por defecto a la vez, de una política criminal razonable ${ }^{41}$.

En este contexto el aporte que puede ofrecer la doctrina pareciera altamente relevante, sea a los efectos de favorecer una adecuada sistematización e interpretación como para apoyar una valoración objetiva de las definiciones del legislador y, en su caso, aportar a su crítica y reformulación ${ }^{42}$. El casuismo, la heterogeneidad, las objeciones de legitimidad y la dicotomía que plantea su amplitud, la permanente revisión y escasa aplicabilidad, debiesen asimismo incentivar dicha atención en tanto resulta evidente que constituye un ámbito de preocupación del legislador penal que resulta altamente problemático y, al mismo tiempo, tremendamente relevante en términos de su trascendencia social.

No obstante, pareciera que estas mismas características han operado en forma opuesta. En concreto, la literatura disponible es escasa, siendo igualmente parco el interés demostrado por la doctrina en torno al tratamiento de estas figuras en particular y de su conjunto en general ${ }^{43}$. Las excepciones tampoco suelen profundizar en el desarrollo de explicaciones, interpretaciones o análisis estructurados a partir de bases conceptuales comunes, en algo que vaya más allá de las referencias de estilo a los contenidos y caracteres generales que son propios del derecho electoral. Con ello se limitan -en su mayoría- a la proposición de aproximaciones clasificatorias o exegéticas basadas en los contenidos de cada tipología en particular, abordando escasa o aisladamente las cuestiones interpretativas que pudiesen ofrecer una mayor complejidad o las tareas propias de la sistematización ${ }^{44}$. Con ello, la doctrina pareciere favorecer y perpetuar el estado de inercia que caracteriza a la baja aplicación de este grupo de delitos, pasando a operar como un auténtico cómplice pasivo, ratificando el escaso interés que existe en la persecución y sanción de estas formas delictivas. En este contexto la valoración de los planteamientos existentes tampoco resulta sencilla, pues las condiciones antedichas promueven un escenario poco propicio para el análisis comparativo.

\footnotetext{
${ }^{41}$ Gálvez y Rubıo (2007), p. 112. Sobre el carácter intencional de este efecto (orientado a la dispersión y desfocalización) respecto del caso del financiamiento electoral, véase Maroto (2015b), pp. 177 y ss.

42 Sobre ello véase Díaz y García Conlledo (2007), p. 127.

43 Al respecto Maroto (2015b), pp. 228 y 229.

${ }^{44}$ CRuz (2013), p. 7; Romero (2005), p. 99. Respecto al caso chileno podemos anticipar que no existe una sola obra dedicada a su tratamiento o sistematización con carácter general, siendo escasas las aportaciones específicas. De todo ello daremos cuenta con más de detalle en breve. Este tratamiento contrasta con el amplio desarrollo que ofrece el análisis de la realidad en la que se insertan estos delitos, especialmente en el campo del derecho público, la sociología y la ciencia política.
} 
De este modo, nuestro objetivo es aportar a la construcción de dichas definiciones de conjunto centradas especialmente en el tratamiento de los intereses dignos de protección, que respaldan el uso de la sanción penal en los delitos electorales y las consecuencias que ello sugiere para precisar la estructura de injusto de dichas infracciones (esto es, la parte general de este conjunto de la parte especial). Por razones de espacio -y en consideración a su propia extensión- no será posible en esta ocasión abordar con detalle o de forma estructurada los diversos problemas que sugiere la tipología de cada figura en particular, sin perjuicio de las referencias y menciones específicas que se incluyen en el desarrollo del texto y de las conclusiones que dicha estructura general nos permitirá sugerir, de cara a la reformulación de este conjunto de delitos (de lege ferenda) y a efectos de su interpretación (de lege lata). Tomaremos como punto de partida el contexto que ofrece nuestro medio local, la caracterización que ha recibido este grupo de delitos a través de la historia y los desarrollos sistemáticos a que ha dado lugar.

\section{Los delitos electorales en el derecho penal chileno}

El derecho positivo chileno constituye una muestra paradigmática de los caracteres que hemos descrito en torno a la regulación de los delitos electorales, en tanto el casuismo y la heterogeneidad de las conductas incriminadas se advierte a simple vista. En la actualidad constituye delito electoral en Chile -y se tipifica en forma independiente- el votar en una misma elección más de una ve ${ }^{45}$; suplantar a un elector o llevar su nombre para sustituirlo en el acto de votación ${ }^{46}$; confeccionar actas de escrutinio de una mesa que no funcionó ${ }^{47}$; apropiarse de urna con votos no escrutados ${ }^{48}$; tener cédulas electorales sin facultad legal ${ }^{49}$; falsificar, sustraer, ocultar o destruir el padrón de una mesa, el acta de escrutinio o la cédula electoral ${ }^{50}$; impedir a otro sufragar por medio de violencia, amenaza, privación de cédula de identidad o equivalente ${ }^{51}$; presionar a un elector discapacitado o a quien lo asiste ${ }^{52}$; impedir ejercer funciones

\footnotetext{
45 Art. 136 Ley No 18.700.

46 Art. 136 Ley No 18.700.

47 Art. 136 Ley N ${ }^{0} 18.700$.

48 Art. 136 Ley $N^{0} 18.700$.

49 Art. 136 Ley No 18.700.

50 Art. 136 Ley № 18.700.

51 Art. 136 Ley No 18.700.

${ }^{52}$ Art. 136 Ley N ${ }^{\circ} 18.700$.
} 
a un miembro de la Junta Electoral o de una mesa receptora de sufragios o de un colegio escrutador o de un delegado ante el colegio escrutador ${ }^{53}$; usar certificados falsos para acreditar impedimentos para ser vocal de mesa o, en general, para cumplir cualquier función prevista en la Ley de Votaciones Populares y Escrutinios ${ }^{54}$; perturbar el orden en lugar en que funcione una junta electoral, mesa receptora o colegio escrutador con el fin de impedir su funcionamiento ${ }^{55}$; solicitar votos por paga, dádiva o promesa y el "cohechar de cualquier forma" a un elector ${ }^{56}$; el vender el voto o sufragar por dádiva o dinero ${ }^{57}$, presumiéndose dicha conducta respecto de quien "deja constancia de la preferencia por cualquier medio" y de quien, luego de recibido el voto, se deja acompañar por un tercero ${ }^{58}$. Asimismo, también constituye delito el alterar la información del registro electoral, padrón electoral, padrón de mesas receptoras de sufragio, nóminas de inhabilitados o cualquier otro dato que sirva para conformar o actualizar el registro electoral ${ }^{59}$; extraviar, dolosa o imprudentemente, documentos, solicitudes de cambio de domicilio o avecindamiento o el destruir datos computacionales de antecedentes del registro o padrón electoral o del padrón de mesas receptoras de sufragio ${ }^{60}$; proporcionar datos falsos o un domicilio electoral diferente a los habilitados al declarar o actualizar domicilio electoral o acreditar avecindamiento ${ }^{61}$; suplantar a un delegado de junta electoral o a un miembro de una mesa o colegio escrutador ${ }^{62}$; suplantar a una persona en una solicitud de cambio de domicilio o avecindamiento y el ocultar, sustraer o destruir una solicitud de cambio de domicilio, de avecindamiento o sus antecedentes de respaldo ${ }^{63}$; modificar el domicilio electoral informado

\footnotetext{
53 Art. 131 Ley No 18.700.

54 Art. 140 Ley $N^{\circ} 18.700$.

55 Art. 131 Ley $N^{0} 18.700$.

${ }^{56}$ Art. 137 inc. $1^{\circ}$ Ley $N^{\circ} 18.700$.

${ }^{57}$ Art. 137 inc. $2^{\circ}$ Ley $N^{\circ} 18.700$. de impedimento.

${ }^{60}$ Art. 56 Ley No 18.556.

${ }^{61}$ Art. 53 Ley No 18.556.

${ }^{62}$ Art. 136 Ley $N^{0} 18.700$.

${ }^{63}$ Art. 53 Ley No 18.556.
}

58 Lo dicho se exceptúa respecto a personas en situación de discapacidad.

59 Art. 54 Ley N N 18.556. La alteración se puede reflejar en la mayoría de los casos en una obstaculización. No obstante, en otros casos provocará una alteración en el desarrollo de las condiciones propias del proceso, por ejemplo, impidiendo que un determinado elector participe en la designación de sus representantes específicos correspondientes al territorio en que radica su domicilio. En dicho caso, el contenido de lo injusto específico es diverso y menos grave que el propio de un acto 
por un elector ${ }^{64}$; incitar, promover, solicitar u organizar electores para que modifiquen su domicilio electoral con datos falsos o usando otros diversos a los que se encuentran habilitados ${ }^{65}$; incurrir en falso testimonio en el patrocinio de candidaturas independientes ${ }^{66}, y$, finalmente, declarar en forma falsa el no estar afiliado a un partido político cuando se asume un cargo incompatible con una afiliación que se encuentra vigente ${ }^{67}$. Por otro lado, también constituye delito el percibir en forma indebida bonos correspondientes al ejercicio de la función de vocal de mesa o miembro o secretario de un colegio escrutador ${ }^{68}$; comercializar los datos de registro o padrón electoral ${ }^{69}$, y, en general, el uso de estos mismos datos para fines comerciales ${ }^{70}$. Asimismo, cometen también delito quienes otorguen u obtengan aportes correspondientes a financiamiento de campañas electorales de personas jurídicas ${ }^{71} \mathrm{o}$ un aporte para una candidatura o partido político que exceda en $40 \%$ el monto de lo permitido en forma individual o en global ${ }^{72}$, y quienes utilicen los aportes o fondos provenientes del fisco en virtud de transferencias, subsidios o derechos establecidos en la ley de partidos políticos en fines distintos a los que lo justifican ${ }^{73}$.

Constituye igualmente delito, pero sólo respecto de los miembros de una mesa receptora de sufragios (es decir, los vocales de mesa), el admitir el sufragio de personas que no figuren en el padrón o que no exhiban cédula

${ }^{64}$ Art. 54 Ley $N^{0}$ 18.556. La prohibición opera incluso cuando el elector modifica a dichos efectos su domicilio al renovar cédula de identidad.

65 Art. 54 Ley N $\mathrm{N}^{0} 18.556$.

66 Art. 128 de la Ley $N^{\circ}$ 18.700. Hay que tener en cuenta que dicho acto supone que el patrocinante declara que no se encuentra afiliado a un partido político constituido o en formación y que debe tener inscripción vigente en la respectiva circunscripción o distrito (arts. 10 y 11 Ley No 18.700). A este respecto se debe tener en cuenta que el "doble patrocinio" y el hecho de no tener inscripción competente solo reciben una sanción -multa- de carácter administrativa (art. 127).

${ }^{67}$ Art. 18 Ley $\mathrm{N}^{\circ} 18.603$.

${ }^{68}$ La ley prevé un pago para quien cumpla funciones como vocal de mesa en el art. 47 bis o como miembro o secretario de un colegio escrutador en el art. 85 bis. La infracción se contempla en el art. 139 Ley $\mathrm{N}^{\circ} 18.700$.

${ }^{69}$ Art. 54 Ley № 18.556; puede que esta conducta incida en una presión posterior respecto del ejercicio del derecho al voto, etc.

70 Art. 53 Ley $\mathrm{N}^{0} 18.556$.

${ }^{71}$ Art. 27 bis. inc. $2^{\circ}$ Ley $N^{0}$ 19.884. La prohibición se establece en el art. 26 de la Ley No 19.884. Se excluyen los aportes aislados inferiores a 50 UF.

72 Art. 27 bis Ley No 19.884

${ }^{73}$ Art. 27 bis inc. $4^{\circ}$ Ley $N^{0} 19.884$. 
de identidad ${ }^{74}$; el recibir votos antes de la hora de apertura o después de la hora de cierre ${ }^{75}$; el hacer una marca o señal en una cédula con el objeto de preconstituir una causal para anular el voto o para violar el secreto del voto ${ }^{76}$; cambiar el lugar de funcionamiento de una mesa receptora de sufragios ${ }^{77}$; impedir la presencia de algún miembro de la mesa o apoderado ${ }^{78}$; negar el sufragio a un elector habilitado o impedir, obstaculizar o dificultar el sufragio de personas con discapacidad ${ }^{79}$; suspender abusivamente la recepción de votos o del escrutinio ${ }^{80}$; retirarse injustificadamente antes del cierre de la mesa ${ }^{81}$; o negarse a tomar nota en el libro de actas de circunstancias relevantes ${ }^{82}$. Estas mismas personas, además de los miembros de una junta electoral y de un colegio escrutador, cometen también delito si funcionan o adoptan acuerdos sin el quorum requerido; sesionan en lugares u horas diversas a las autorizadas en la ley ${ }^{83}$; incumplen los deberes relativos a recibir y devolver útiles, sobres, actas y registros en el plazo legal o los pierden o entregan antes de la hora permitida ${ }^{84}$. Por su parte, comete también delito el delegado de junta electoral que no constituye las mesas conforme a procedimiento legal (con quienes se ofrezcan como voluntarios conforme al procedimiento legal) ${ }^{85} \mathrm{O}$

\footnotetext{
${ }^{74}$ Art. 132 Ley $\mathrm{N}^{\circ} 18.700$.

${ }^{75}$ Art. 132 Ley № 18.700. La prohibición no opera si a la hora de cierre hay personas en la fila para emitir sufragio, y hasta que lo hayan hecho todos los que estaban en dicha condición conforme detalla el art. 68 de esta misma ley.

${ }^{76}$ Art. 132 Ley No 18.700.

77 Art. 132 Ley $\mathrm{N}^{\circ} 18.700$

${ }^{78}$ Art. 132 Ley No 18.700. La prohibición no opera si se ha integrado ("constituido") la mesa en forma reglamentaria por retardo de los miembros titulares (vocales).

${ }^{79}$ Art. 132 Ley $\mathrm{N}^{\circ} 18.700$.

${ }^{80}$ Art. 132 Ley No 18.700.

${ }^{81}$ Art. 132 Ley $N^{\circ} 18.700$. El art. 68 de la Ley $N^{\circ} 18.700$ detalla que el cierre se debe realizar a las 18.00 hrs. Hay que tener en cuenta además que el delegado de una Junta Electoral y el miembro de una mesa receptora o de un colegio escrutador que no concurra a sus funciones no tiene sanción penal. Sólo se le impone una multa a beneficio municipal (art. 138 Ley $\mathrm{N}^{\circ}$ 18.700).
}

${ }^{82}$ Art. 132 Ley No 18.700.

${ }^{83}$ Art. 133 Ley No 18.700

${ }^{84}$ Art. 134 Ley $N^{\circ} 18.700$. Con respecto a esto último hay que tener en cuenta que el art. 57 de este mismo cuerpo legal regula específicamente su entrega a las 8 de la mañana el mismo día en que funcionarían las mesas. El objetivo es claro: reducir el riesgo de adulteración del contenido de dichos objetos en términos que puedan generar incidencias indebidas en el desarrollo del proceso electoral.

${ }^{85}$ El procedimiento indica que debe llamarse a voluntarios y se encuentra establecido en el art. 57 inc. $4^{\circ}$ de la Ley $\mathrm{N}^{\circ}$ 18.700. No se sanciona el no constituirla, sino el hacerlo conforme a un criterio 
que le impide a un apoderado ejercer sus funciones, les retira las carpetas o credenciales o los expulsa del local ${ }^{86}$, y quienes ejercen funciones como jefes de las fuerzas de orden si no prestan cooperación al ser requeridos por autoridad competente ${ }^{87}$; o si dejan sin efecto las medidas que hubiesen sido instruidas por la autoridad en el ámbito de sus atribuciones ${ }^{88}$.

Finalmente, cometen también delito los notarios que autorizaren el patrocinio de una candidatura sin verificar la comparecencia personal correspondiente ${ }^{89}$; los administradores electorales, administradores generales electorales o administradores generales de fondos de un partido político, que proporcionen o certifiquen antecedentes o hechos falsos ${ }^{90}$; los funcionarios del Servicio Electoral que violen la reserva de los aportes menores sin publicidad ${ }^{91} y$, en general, los Funcionarios del Servicio Electoral y quienes desempeñen funciones en dicho servicio que incurran el violación de reserva ${ }^{92}$; los funcionarios y quienes presten funciones en Servicio Electoral que militen en partidos políticos, participen o adhieran a reuniones, manifestaciones, asambleas, publicaciones o actos político partidistas o de apoyo a candidatos u opciones en plebiscitos ${ }^{93}$, y los responsables del ingreso informático de "resultados" de un proceso electoral que los omitan, alteren o destruyan ${ }^{94}$.

Este extenso catálogo no se condice con el escaso margen de aplicación que dicha tipología recibe en términos prácticos. Al margen de aquellas conductas de reciente incorporación -y que, en la práctica, casi no han tenido

diverso de forma que constituye un riesgo para la "integralidad" del proceso más que una obstaculización al mismo.

${ }^{86}$ Art. 134 bis Ley $N^{0} 18.700$.

87 Art. 141 Ley $N^{0} 18.700$.

${ }^{88}$ Art. 141 Ley $N^{0} 18.700$.

${ }^{89}$ Art. 129 Ley $\mathrm{N}^{0} 18.700$.

90 Art. 27 ter Ley $N^{0} 19.884$.

91 Art. 17 Ley N N 19.884. La pena se regula según el tipo de operación "protegida" que es objeto de publicidad, sin que queden claras las razones de las diferencias penológicas previstas.

92 Art. 71 Ley $N^{0} 18.556$.

93 Art. 71 Ley $\mathrm{N}^{0} 18.556$.

${ }^{94}$ Art. 135 Ley $N^{0}$ 18.700. A dicho respecto se debe tener en cuenta que, conforme al inciso segundo del art. 175 bis de la Ley $N^{0}$ 18.700, estos funcionarios son las personas que estuvieren acreditadas en cada mesa por el Servicio Electoral y sus ayudantes técnicos. 
oportunidad de operar ${ }^{95}$ - los datos que ofrece el Ministerio Público dan cuenta de un total de 367 casos ingresados a tramitación a nivel nacional entre los años 2010 y junio de 2017, todos asociados a la comisión de una única infracción ${ }^{96}$. El bajo número de casos en total (que arroja un promedio de 48 casos anuales ${ }^{97}$ ), Ilama aún más la atención si se tiene en cuenta que solo en un $1,8 \%$ se registra una sentencia condenatoria en términos continuos; un $3,6 \%$ presentan una suspensión condicional y en un $0,1 \%$ se resuelve a través de un acuerdo reparatorio. Del saldo, prácticamente la mitad (49,2\%) fue objeto de alguna medida de término en sede de instrucción, mientras que poco menos del $14 \%$ culmina descartando la condena (sobreseimiento definitivo o absolución ${ }^{98}$. Debemos reconocer que la constante de estas cifras se quiebra de manera coyuntural en el año 2016, registrándose en la fiscalía Centro Norte un universo de 148 condenas que escapan a toda previsión ${ }^{99}$. Lo propio sucede en el año 2013 en la Fiscalía oriente, donde se registran 141 decisiones asociadas a no iniciar investigación, hitos de carácter excepcional asociados a situaciones coyunturales, que solo confirman la baja prevalencia de casos y condenas.

La atención brindada por la doctrina tampoco hace excepción. Las aportaciones conocidas en Chile se limitan a tres contribuciones específicas -y recientes-además de la mención de corte descriptivo que se contiene en la

\footnotetext{
${ }^{95}$ A la fecha de cierre del presente texto solo ha tenido lugar un acto eleccionario posterior a la vigencia de las últimas reformas penales recaídas sobre la materia (relativo a las elecciones presidenciales y parlamentarias acaecidas los días 19 de noviembre y 17 de diciembre de 2017), sin que hasta esta fecha existan datos certeros sobre el curso que pudiesen tener las correspondientes denuncias.

${ }^{96}$ La información reportada fue solicitada vía consulta formal al Ministerio Público, quien dio respuesta al requerimiento mediante Carta individualizada como DEN/LT № 286/2017. La información proporcionada se restringió a las categorías codificadas por la institución, que abarcan esencialmente los delitos previstos en los arts. 128 a 141 de la Ley № 18.700 y una hipótesis adicional contenida en la Ley No 18.603.

${ }^{97}$ El hecho de que los casos aparezcan conectados al desarrollo de los procesos electorales no altera este promedio, pues si bien las denuncias o inicios suelen concentrarse en el año del respectivo proceso y en el inmediato que le sigue, el desenlace procesal ( $y$, en su caso, la respectiva condena), se distribuye de forma pareja en todos los períodos por igual.

${ }_{98}$ El total de "términos" registrados en el Ministerio Público no se distribuye en forma lineal en relación a la cifra de casos que se denuncian. Ello sucede -hasta donde alcanzamos a ver- no solo porque se contabilizan "hitos" que no representan un cese real en la gestión del caso, sino que solo afecta al respectivo ingreso registrado (como en los casos de incompetencia, acumulación, etc.). Además, los términos se registran por individuo, de forma que una denuncia puede reflejarse en muchos de ellos, según cual fuere el número de sujetos cuya responsabilidad se investiga.

${ }^{99} \mathrm{Si}$ estos casos se hubieran contabilizado en el total, la cifra de condenas se incrementaría sensiblemente (hasta un 19\%), dejando una imagen errónea sobre su real dimensión. De ahí que hayamos preferido consignarlas en forma separada.
} 
obra general de Alfredo Etcheberry ${ }^{100}$. Por sobre esta última relación sobre el contenido de una parte de los tipos ${ }^{101}$, Claudia Ortega Forner ${ }^{102}$ nos propone un primer desarrollo específico que, a pesar de ello, presenta una aproximación expositiva y muy sintética, que ella misma califica como una "reseña general"103. Aborda solo una relación casi nominal de una parte de la tipología vigente -incluso más reducida a la propuesta por Etcheberry- acompañada del tratamiento de las reglas especiales de prescripción y de una síntesis de cuatro casos de jurisprudencia coetáneos a la fecha del texto. Posteriormente -en tiempos muy recientes- Angélica Torres Figueroa ${ }^{104}$ se ocupa de analizar los tipos penales asociados específicamente al financiamiento electoral -y de partidos políticos- creados por la Ley $N^{\circ} 20.900$, ofreciendo un desarrollo exegético correctamente estructurado a partir de la sistemática de las reglas aplicables al financiamiento y desarrollo del proceso electoral y de la historia de la ley que los introduce. Por último, José Luis Guzmán Dálbora ${ }^{105}$ se ocupa de las problemáticas que ofrece el tratamiento del cohecho político, desde una perspectiva de carácter histórico centrada en la conceptualización del bien jurídico.

Se podrá advertir que las dos primeras aportaciones obedecen a la necesidad-casi imperiosa- del Ministerio Público de contar con elementos de juicio que favorezcan la aplicación e interpretación de las figuras analizadas, que constituyen aportaciones de carácter parcial sobre este universo de delitos y que no profundizan en contenidos que excedan el desarrollo descriptivo o exegético, respectivamente. Lo propio sucede con la breve síntesis que propone Etcheberry -al margen del valor que tiene el solo hecho de su consideración en una obra de carácter general, en atención a su especificidad-mientras que el trabajo de Guzmán Dálbora, de mayor profundidad, solo funda sus objetivos

\footnotetext{
100 Debemos mencionar además que en el año 2016 se publicó en nuestro país una contribución adicional, pero referida a derecho comparado. Se trata concretamente de un trabajo de CAMBRONERO (2016), pp. 45-72.

101 ETCheBeRRY (1997), pp. 281-283. No obstante ser la obra más genérica, que aborda el mayor número de delitos previstos en este grupo en particular, y que asume una presentación de corte descriptiva, constituye a nuestro juicio la que en mayor medida adopta posturas que demandan una aproximación sistemática.

102 Ortega (2007), pp. 30-38.

103 Ortega (2007), p. 38.

104 Torres (2016), pp. 25-53.

105 GuzMán (2017), pp. 163-202.
} 
en el tratamiento de una cuestión particular asociada a la regulación del llamado cohecho electoral ${ }^{106}$.

Estos antecedentes reafirman la necesidad de avanzar en los objetivos propuestos, sea a los efectos de contar con contenidos de base que habiliten al desarrollo de interpretaciones más precisas de la tipología vigente; para contar con criterios que sean idóneos para alimentar los procesos y herramientas que inciden en las consecuencias previstas en la ley para las diversas infracciones - desde la aplicación del principio de oportunidad y hasta la determinación de la pena-, y, finalmente, para el análisis de la conveniencia, suficiencia y pertinencia de las decisiones propuestas por el legislador, tanto en lo referido a las conductas incriminadas como en lo relativo a su sanción.

\section{Caracterización histórica o "tradicional" de los delitos electorales}

El contenido de la regulación chilena resulta ilustrativo de la fisonomía general -y común-que hemos ya anticipado ${ }^{107}$. En particular, permite advertir que no se trata solo de un conjunto que se estructura a partir de numerosas conductas incriminadas, diversas entre sí y dispersas en su contenido, sino de una regulación que se identifica en forma característica por el recurso a descripciones ampliamente heterogéneas en las que se recurre exageradamente a una pluralidad de modalidades o formas de comisión, que aparecen desagregadas en atención a una pluralidad de factores que no responden a una lógica común ${ }^{108}$. Entre ellos, se ocupan las diversas clases de funciones adscritas a la operatoria de los procesos electorales (vocal, miembro de mesas receptoras, colegios escrutadores, administrador electoral, etc.), las correspondientes dimensiones o hitos que las configuran (preparación del

\footnotetext{
106 En términos precisos esta contribución aborda en exclusiva -en lo que acá nos ocupa- de desacreditar las razones que favorecen la sanción del votante que ha sido "sobornado" en cuanto titular del derecho que resulta afectado por la "compra de votos", acotando a dicha problemática sus objetivos precisos (GuZMán (2017), pp. 180-184). En lo demás (GuZMán (2017), pp. 184 y ss.), se ocupa del tratamiento del Ilamado "cohecho parlamentario", asociado específicamente a la conveniencia o necesidad de prever una disposición incriminatoria específica y adicional a la que ofrece el delito de cohecho funcionario "tradicional".

$107 \mathrm{Al}$ respecto véase Maroto (2015b), p. 181.

108 En cualquier caso, existe una percepción común que pareciera respaldar esta definición pues, como indica MARTí y MuÑoz (2008), p. 5, son numerosas y diversas las formas de incidir en el desarrollo y resultados de los procesos electorales en términos prácticos. En este mismo sentido LeHOUCQ (2007), p. 18, sostiene que "existen muchas formas clandestinas de incrementar los totales de los votos, desde las violaciones de procedimiento hasta la coerción abierta durante la jornada electoral. El estudio sobre Costa Rica revela que los partidos combinaron por lo menos 47 tipos de fraude (Lehoucq y Molina, 2002). Aunque puede no haber un número infinito de maneras de manipular los resultados de los comicios, las técnicas para manipular los votos son variadas e ingeniosas".
} 
registro o padrón electoral, acto de votación, escrutinio, propaganda electoral, etc.) y, finalmente, una serie de caracteres secundarios que parecieran haber sido considerados como relevantes para la identificación de diversas modalidades de ejecución -condiciones de tiempo u objetos sobre los que recaen las conductas (voto, acta, escrutinio, documentos de apoyo o soporte, etc.)-. Con ello el panorama que se ofrece al aplicador del derecho $-y$ por supuesto al intérprete- plantea serias dificultades para una adecuada sistematización, pues el único contenido que se advierte como genérico y común respecto de todas las formas comisivas es el que su ejecución se encuentra asociada o condicionada por el contexto que ofrece el desarrollo de los procesos electorales.

Sobre esa base, no debe parecer extraño que se tienda intuitivamente a considerar que el propio proceso electoral constituye un objeto de referencia y protección de este conjunto de figuras (esto es, el bien jurídico protegido), como ha ocurrido en tiempos relativamente recientes en una parte importante de la doctrina. No obstante, dicha asunción no jugó un papel importante (y menos aún uno dominante) sino hasta tiempos bastante recientes, inclinándose la mayoría de las opiniones a través de la historia por una conceptualización de estas figuras distinta, entre las que priman las interpretaciones que conciben a los delitos electorales como un conjunto de naturaleza heterogéneo, que responde a necesidades de protección de intereses o bienes jurídicos diversos entre sí109. Dicha conclusión se afirma teniendo en cuenta que su dispersión y heterogeneidad hace difícil identificar un mismo y único referente de protección en común, pero también el que permite evidenciar similitudes importantes con una serie de modalidades comisivas que son propias de delitos previstos en la legislación penal común (fraudes, coacciones, falsedades, engaños, etc.). Bajo dichas opiniones la conexión de su ejecución con el desarrollo del proceso electoral, cumpliría solo un papel secundario -de contexto- pues su afectación -que no se discute- llevaría solamente a

\footnotetext{
109 En esta línea destaca la opinión de OrTs (1977), p. 273, quien sostuvo hace algunas décadas que a dichos efectos lo relevante es analizar los contenidos de cada grupo de delitos para luego proceder a verificar si presentan alguna unidad, alternativa que luego descarta implícitamente. Próximo a lo sostenido en el texto PATIÑO (2012), pp. 51 y ss., quien expresamente afirma que cada delito protege un bien jurídico específico y diverso, a pesar de que en otros pasajes de su contribución sostiene que en, términos abstractos y generales, cada uno de ellos afecta a "la función electoral" y a "las instituciones democráticas y republicanas asociadas a la representación popular". Otros operan sobre bases similares de manera implícita toda vez que mencionan referentes diversos a la hora de tratar el objeto de protección de las diversas figuras delictivas. Así se aprecia en GÁlvEZ y RuBıO (2007), pp. 116 y 117, quienes entienden que algunos delitos inciden sobre el "libre ejercicio del derecho a voto" mientras que JiménEz (1994), p. 28, hace lo propio adscribiendo parte de las figuras delictivas a la protección de la "pureza y transparencia" del proceso electoral.
} 
asignarle una "mayor gravedad" a su comisión"110. Se concluye por ello que los delitos electorales son formas comisivas agravadas que se estructuran a partir de delitos que forman parte de la regulación penal común ${ }^{111}$, de forma que su identificación bajo un mismo rótulo -como "delitos electorales"- no altera su reconocimiento como figuras de coacción, falsedades, sustracciones, fraudes o sobornos (entre otros) $)^{112}$.

Desde esta perspectiva, quien es amenazado con perder el empleo si no vota por un determinado candidato se consideraría víctima de una amenaza condicional, cuya ejecución resulta más gravosa en comparación con los demás casos penalizados, por comprometer un ámbito de expresión de su libertad que detenta una particular relevancia (la emisión del voto en el proceso electoral). Asimismo, quien fuerza a otro a sufragar en un determinado sentido incurre a fin de cuentas en una coacción, pero una coacción que también resultaría más gravosa toda vez que incide en la libre realización de este mismo tipo de actividad. Asimismo, el vocal de mesa que sustrae una urna con votos no escrutados a efectos de recibir el beneficio económico que se le ha ofrecido, incurre a fin de cuentas en un delito de cohecho que presentaría por esa misma razón una mayor gravedad. Finalmente, quien abusando de su oficio aprovecha sus potestades para adulterar el padrón electoral o el acta de escrutinio de una votación, incurriría en una hipótesis de falsificación documental cuya ejecución se tornaría más gravosa por incidir en un ámbito en el que la fe pública cumple una función social de particular relevancia.

Ahora bien, esta conceptualización aparece desarrollada en base a dos formas de aproximación alternativas, cuyos contenidos sin embargo resultan equivales a los efectos que nos ocupan. Para un primer sector-dominante en lugares como España- lo relevante es distinguir aquellas conductas que importan un abuso en el ejercicio de funciones públicas, diferenciándolas de aquellas que regulan la conducta de particulares y que necesariamente presentan una menor relevancia ${ }^{113}$. Para otros -en un criterio que resulta dominante en lugares como México- lo relevante es diferenciar las conductas a partir del modo comisivo o la forma de ejecución que caracteriza a cada una de ellas

\footnotetext{
110 Muñoz (1983), p. 463; Faraldo (2014), p. 166; Faraldo (2012), p. 183; Jiménez (1994), p. 12 y, especialmente JIMÉNEZ (1994), p. 15.

111 Con carácter general, Altes (1999), p. 170; Faraldo (2014), p. 166; MuÑoz (2015), p. 748.

112 En este sentido, MuÑOz (2015), p. 748.

113 Betanzos (2012), p. 111, en México y en España de Urbano (2011), p. 2; Patiño (2012), pp. 40 y 43 y ss. Gálvez y Rubio (2007), p. 9; Polanco (2011), pp. 8 y ss.; Cruz (2013), p. 11; Muñoz (1983), p. 465 y ss. Este esquema de aproximación se puede identificar implícitamente en el desarrollo propuesto en nuestro medio por Ortega (2007), pp. 33-34.
} 
en forma particular, tomando como base a las que se encuentran previstas en la legislación penal común y que resultan similares o, cuando menos, equivalentes a aquellas que configuran delitos electorales ${ }^{114}$. Los partidarios de la primera aproximación entienden que el grupo de delitos propiamente "funcionarios" responden en esencia a la lógica de la infracción o abuso en el ejercicio de funciones públicas (asociadas al quebrantamiento del interés público o a faltas a la probidad), cuya especificidad radica en estos casos en la particular entidad o relevancia social que tienen las funciones asociadas al régimen de organización institucional de los poderes públicos (respecto de los cuales los procesos electorales cumplen un papel estructural) ${ }^{115}$. Se trataría de casos correspondientes a abusos funcionarios de mayor entidad o gravedad comparativa en relación a los previstos en el régimen penal común, que por ello, carecen de diferencias esenciales en su naturaleza o estructura respecto a cualquier otro delito funcionario ${ }^{116}$. Avala esta aproximación, el hecho de que las regulaciones positivas suelen distinguir los tipos de infracción punibles a partir de las diversas funciones que corresponde desempeñar a los actores públicos

114 Por todos se puede consultar la estructuración propuesta por FeRnández y Ojesto (2007), pp. 1029-1036, en la medida que da cuenta en forma más acabada del desarrollo doctrinal adscrito a esta modalidad de sistematización. En un sentido equivalente, pero menos completo, Altes (1999), p. 172; Gálvez y Rubio (2007), p. 116; Betanzos (2012), pp. 110 y 111. También en Jiménez (1994), pp. 25 y 26, si bien con matices. En Chile es posible advertir una metodología de aproximación equivalente en Etcheberry (1997), pp. 281-283. En un sentido opuesto Bravo y Leal (2011), p. 18.

115 Subyace implícita -salvo contadas excepciones- la idea de que los elementos esenciales con que debe contar todo proceso electoral -y que dan cuenta de la legitimidad de sus resultados- se garantizan a través de la previsión y ejercicio de determinadas funciones institucionales y sus correspondientes controles, siendo éste el elemento que lleva a atribuirles una relevancia particular en comparación con las conductas de particulares que generan incidencias similares. Por esta misma razón se suele utilizar, a estos efectos, una noción amplia de "funcionario" que incluye a todos los particulares que intervienen en el desarrollo de un rol institucional (como sucede en el caso chileno con el papel atribuido al "vocal" de una mesa receptora de sufragios). Para ello se requiere en la mayoría de los casos de una consagración positiva formal, como sucede en lugares como España o México, donde se regula un criterio estrictamente funcional a dichos efectos (más amplio al previsto en la regulación en general). Sobre el derecho español véase Rodríguez (2006), p. 20 y Romero (2005), pp. 119 y 120; sobre la regulación mexicana, PATIÑo (2012), p. 41 y PolAnCO (2011), p. 15. Con carácter general, véase Martí y Muñoz (2008), p. 3; De Urbano (2011), p. 2. En nuestro medio la amplitud de la definición de funcionario público contenida en el art. 260 del Código Penal hace innecesaria una aclaración equivalente, pues no parece discutible que el particular que cumple funciones formales en el marco de un proceso electoral es considerado como funcionario en relación a dicho desempeño. En este mismo sentido, en Chile, Ortega (2007), p. 33.

116 Constituirían asimismo delitos asociado a la idea de la infracción de deberes, con todas las consecuencias que ello acarrea en materia de participación. Al respecto Altes (1999), p. 174; FERNÁNDEZ y Ojesto (2007), p. 1027; Muñoz (1983), p. 469; Peñaranda (1986), p. 1128. 
en el curso o desarrollo de los procesos electorales ${ }^{117}$. La conceptualización de las demás conductas -"de particulares"- recibe un tratamiento dispar en este contexto, pues al margen de la función pública no se advierten otros elementos comunes que favorezcan una determinada ordenación o clasificación. De ahí que se las termine por definir -aleatoriamente y de forma irregular-a partir de las similitudes que presentan con otras formas de conductas punibles que se identifican en la legislación penal común (como sucede con el cohecho, el fraude o la falsificación) ${ }^{118}$.

El segundo grupo de opiniones asume una óptica equivalente a la recién comentada, pero esta vez con carácter general. La idea de base es que cada una de las modalidades o formas comisivas propuestas por el legislador, opera como criterio relevante para una adecuada sistematización. En este sentido ${ }^{119}$, se identifica tras la idea de "fraude" a las conductas de quienes recurren al engaño para afectar el carácter unitario e igualitario del voto (asociado a quienes votan en forma reiterada o sin tener derecho a hacerlo); a la noción de "soborno $o$ cohecho" respecto a quienes ofrecen o reciben beneficios individuales por adoptar una determinada preferencia a la hora de emitir el sufragio o por el hecho de abstenerse de hacerlo; a la de "coacción" en relación a quienes inciden sobre la libertad individual al sufragar, y a la de "falsedad" para graficar el sentido de las conductas que consisten en la adulteración o falseamiento de los registros electorales, votos, actas de escrutinios y hasta la propia suplantación de identidad (respecto de quienes emiten el voto en el lugar de otro elector). Adicionalmente, se identifican en forma paralela una amplia gama de actos relativos a la "obstrucción del proceso electoral", incluyendo la pérdida o destrucción de documentos u objetos necesarios para su desarrollo; al "abandono de funciones" en relación a los actos esenciales del proceso electoral; a la provocación de "desórdenes públicos" o la "tenencia de armas", cuando tienen lugar en lugares próximos a aquellos donde se realizan las votaciones o el recuento de votos; a la realización de "concentraciones o manifestaciones"

\footnotetext{
117 Por esta razón JiMÉNEZ (1994), pp. 8-10, entiende que no es necesario recurrir a definiciones generales o interpretaciones amplias sobre qué se considera como funcionario público a estos efectos, pues lo usual es que el legislador describa en términos más precisos la caracterización del sujeto activo cuando es relevante, especificando casi siempre algún tipo de función concreta.

${ }^{118}$ Este hecho, unido al carácter marginal y aislado que representan en cuanto a su potencialidad lesiva para el desarrollo del proceso electoral, Ileva a que no suelan ser abordados en cuanto delitos electorales con algún grado mayor de detalle o en base a la identificación de criterios comunes o uniformes bajo esta formulación.

119 Tomamos como base la estructuración propuesta por Fernández y OJesto (2007), pp. 1029-1036, por su carácter representativo. Esta categorización presenta además la ventaja de ser expuesta en el marco de un estudio comparativo de la realidad que ofrecen las regulaciones latinoamericanas.
} 
en dichos lugares y contextos y, finalmente, a diversos actos de "apropiación o malversación" recaídos en objetos o dinero asociado al desarrollo del proceso electoral ${ }^{120}$. Se podrá advertir con facilidad que no es posible sostener que la conceptualización de estas figuras -al menos, en su amplia mayoría- se encuentre estructurada a partir de la regulación penal común ${ }^{121}$.

Esta forma de conceptualizar los delitos electorales sugiere una serie de efectos o consecuencias que vale la pena destacar ${ }^{122}$. En primer lugar, lleva a asumir -y así se hace de forma generalizada- que prácticamente no existen delitos "propiamente electorales", constituyendo las excepciones hipótesis escasas y marginales que carecen de relevancia a efectos de su sistematización ${ }^{123}$. Dicha asunción resulta relevante en tanto confirma la idea de que los procesos electorales constituyen un ámbito que no cumple un rol de manera autónoma como referente de protección a efectos jurídico-penales, a pesar de su indiscutible trascendencia o entidad institucional. En segundo lugar, ofrece efectos relevantes para el análisis y precisión de la estructura de injusto de cada forma comisiva, en cuanto motiva exigencias dogmáticas e interpretativas de uso común que en ocasiones supera el contexto y contenido que ofrece la tipología de que se trata, ya sea en atención a condiciones propias de los delitos de base que definen su estructura o en función de la necesidad de vincular su aplicación sobre el desarrollo de los procesos electorales. Para ello, se recurre a la exigencia de condiciones de tiempo -asociadas a las fases formales de

\footnotetext{
120 Se incluyen en ello la mayoría de las formas de financiamiento irregular de campañas políticas, representativas de figuras de fraude de subvenciones, irregularidades financieras, contables o falsedades orientadas a fines patrimoniales en general.

121 Se puede advertir una conceptualización equivalente -implícita- en el desarrollo propuesto en Chile por Guzmán Dálbora, especialmente a la hora en que sugiere un paralelo entre el cohecho electoral y el parlamentario, como expresiones o variantes del mismo contenido o supuesto. Al respecto véase, GuZmán (2017), pp. 166 y ss.

122 Cabe advertir que los efectos que pasamos a reseñar no corresponden a una sistemática común, siendo más bien afirmados en forma aleatoria y no necesariamente coincidente en todos los casos citados en doctrina.

123 En un sentido relativamente diverso JIMÉNEZ (1994), pp. 25 y 26. Desde su perspectiva son delitos "propiamente electorales" ciertos casos de incumplimiento de normas que regulan el proceso (incluyendo casos de falsedad o abandono de funciones); el emitir dos veces el sufragio; los casos de propaganda ilegal y la presentación o publicación de encuestas ilegales, entre otras, siendo parcial la utilización de delitos comunes o de base para la configuración de las demás figuras.
} 
desarrollo del proceso electoral ${ }^{124}-$, a elementos subjetivos especiales ${ }^{125}$ o a la constatación de signos que den cuenta de una concreta lesividad que permitan conectar la conducta con el plus de lesividad que supone la afectación del proceso electoral ${ }^{126}$.

En tercer lugar, ofrece consecuencias relevantes en materia concursal. Así por ejemplo, en la amplia mayoría de las opiniones se advierte una relación de especialidad y por ende de concurso aparente entre las potenciales figuras concurrentes en el contexto de ejecución de los delitos electorales ${ }^{127}$, en tanto se asume que el correspondiente delito electoral desplaza a la figura común que le sirve de base ${ }^{128}$. También se asume que la realización de una

124 En concreto, se asume que los delitos electorales solo podrían tener lugar en el contexto que fija el desarrollo del proceso electoral y que va, por regla general, desde la definición del padrón electoral hasta el escrutinio (MuÑoz (1983), p. 461), en términos que es dicho contexto el que fija una condición de tiempo que demarca o delimita su ámbito propio. A partir del mismo se determinan también la relevancia de las irregularidades asociadas a la campaña, la propaganda electoral y su financiación, separando esta última del financiamiento de los partidos. Cada uno de esos momentos, y solo ellos, ofrecerían relevancia para la incriminación bajo este rótulo (MARTí y MuÑoz (2008), p. 5; CRUZ (2013), pp. 3 y 4). Al respecto véanse también las definiciones propuestas en el contexto mexicano (si bien con un sentido levemente diverso) en POLANCO (2011), pp. 5 y 6.

125 Se sostiene por ejemplo que en estas figuras el dolo debe estar asociado a la posibilidad de que la conducta ejecutada genere una interferencia en el proceso electoral, con independencia de que dicha exigencia no suele mencionarse en forma expresa en las respectivas tipologías, constituyendo un elemento de tendencia implícito (POLANCO (2011), p. 10).

126 Es usual que se sostenga que en buena parte de estos delitos su aplicación se encuentra acotada a aquellas formas de ejecución que provoquen efectivamente una alteración en los resultados del escrutinio (GÁlvez y RuBıo (2007), p. 117), debiendo en los demás casos quedar impunes. Así sucede paradigmáticamente con las falsedades (por ejemplo, mediante la alteración de la papeleta o del sobre).

127 Rodríguez (2006), p. 7.

${ }^{128}$ Cabe destacar que la regulación española prevé a este respecto una regla de derecho positivo (art. 136 de la Ley Orgánica N 5/1985 de Régimen Electoral General) que ha sido uniformemente interpretada como una cláusula de alternatividad, favoreciendo por ello la aplicabilidad exclusiva de la figura que amerite, en concreto, una mayor penalidad, disposición que la doctrina justifica precisamente por el hecho de que se trata de delitos - casi todos- que pueden castigarse a partir de la regulación penal común. En este sentido MuÑoz (1983), p. 463; FARALdo (2014), p. 166; Faraldo (2012), p. 183. Si bien dicha regla se basa en la aplicación de un criterio diverso al que surge del principio de especialidad y permite la aplicabilidad del delito común o, en su caso, del especial -según cual fuere el que propone una penalidad más severa- basta una breve revisión de sus efectos prácticos para advertir que los fundamentos que la respaldan resultan plenamente coincidentes con lo sostenido. Primero, pues confirma la idea de que se trata de un concurso aparente de leyes penales y, segundo, pues la incorporación de dicha regla evidencia la pretensión del legislador de asegurar a todo evento la aplicación de la penalidad superior, descartando, formal y expresamente que la consagración de un delito electoral pudiese llegar a suponer una atenuación en la responsabilidad concurrente. En concreto, si el delito electoral detenta la mayor pena desplaza por ese hecho -por disposición de la ley- al delito común, pero si sucede lo contrario resultará completamente inaplicable. Dicho resultado ratifica la naturaleza común de ambas figuras y reafirma el sentido agravatorio de la 
pluralidad de hipótesis delictivas en el contexto de un mismo proceso electoral configura un concurso material de delitos (constituyen hechos diversos que afectan a una pluralidad de intereses diversos) ${ }^{129}$. Así, quien adultera o falsifica el padrón electoral, sustrae urnas o votos dentro de ellas e incurre además en compra de votos o coacción electoral, materializa una pluralidad de afectaciones independientes que dan lugar a la sanción de cada una de las formas o tipos de delito en que se haya incurrido, en la medida que se refieran a intereses específicos, bienes jurídicos y sujetos diversos, sin que sea tolerable la aplicación adicional de la falsedad documental o, en su caso, del hurto. Además, se debiera concluir en nuestro derecho positivo que los delitos electorales no configurarían necesariamente delitos de la misma especie a efectos de la aplicación del art. 351 del Código Procesal Penal ${ }^{130}$; no ameritan, en su caso, la aplicación de la llamada reincidencia específica -prevista en el art. 12 número 16 del Código Penal chileno; siendo también claro que la

legislación penal electoral como una propiedad característica. Debemos reconocer que un sector de la doctrina española -minoritario, pero importante- sugiere que la aplicabilidad de esta regla sobre dichos casos solo opera en la medida en que no sea posible advertir previamente una relación de especialidad, debiendo en tal caso aplicarse la pena que haya sido prevista en el delito especial, aun cuando fuese menor. Lo relevante es que el fundamento de dicha propuesta radica en lo inadecuado que resulta corregir los errores del legislador por vía interpretativa, máxime si ello pasa por negar vigencia o aplicabilidad a una regla clara y expresa de derecho positivo, teniendo en cuenta para ello que el sentido del tratamiento especial que proponen los delitos electorales se orienta siempre, y sin excepciones, a proponer formas delictivas de carácter agravado. En este sentido véase MARTí y Muñoz (2008), p. 4; Peñaranda (1986), p. 1106, y Rodríguez (2006), p. 7 (con desarrollo adicional de casos concretos en pp. 18 a 20). De hecho, PeÑaranda (1986), p. 1106, destaca que la regla de alternatividad no debiese ser siquiera necesaria por dicha razón.

129 En este sentido MuÑoz (1983), p. 470. Solo de forma muy excepcional se sostiene la presencia de una relación de absorción -relevante, en cuanto supondría reconocer que el delito común o de base no constituye un elemento central, sino solo un medio o forma comisiva o, en cualquier caso, un aspecto secundario- concentrándose preferentemente en la existencia de relaciones donde uno de los delitos constituye la concreción de otra que opera en forma anticipada. Así sucedería, por ejemplo, respecto de la falsificación de un padrón electoral que tiene por objeto habilitar a que un elector vote más de una vez, en una o más mesas receptoras. Al respecto véase MuÑoz (1983), p. 470.

130 Se trata de una consecuencia ineludible si se interpreta que cada modalidad de ataque se orienta a la protección de bienes diversos. Al respecto resulta ilustrativa la exposición de RoDRíGUEz (2006), p. 10. Bajo dichos supuestos se debe también descartar la idea de que la eventual conceptualización de estos delitos como hipótesis pluriofensivas (que afectan su propio bien jurídico además del proceso electoral) habilite a adoptar una conclusión diversa, salvo para quienes entienden que la sola conjunción en torno a un interés resulta suficiente (en este sentido Oliver (2013), p. 171). Al margen de quienes exigen identidad absoluta (PolitTof et al. (2004), p. 396, comentarios) los criterios distintivos ofrecidos por la doctrina para resolver dichos casos tampoco permiten considerarlos como figuras de la misma especie a dichos efectos. En concreto, esa es la conclusión a la que debiesen arribar quienes sostienen la necesidad de recurrir al modo de ataque a efectos complementarios (Cury (2007), p. 512) o de quienes entienden que debe atenderse a aquel que juega un papel sistemáticamente dominante (MAÑALICH (2015), p. 212). 
ejecución de una pluralidad de hipótesis de diversa configuración debe ser tratada como un concurso real de delitos (si no es ejecutada a propósito de una misma conducta o hecho).

Ahora bien, son múltiples las razones que llevan a concluir que esta conceptualización es errónea. Hay que tener en cuenta en primer lugar que no todas las conductas incriminadas bajo este rótulo encuentran correspondencia en delitos previstos en la legislación penal común. Es más, ello no sucede precisamente con buena parte de las figuras que de forma paradigmática se identifican como delitos electorales y que coinciden, además, con las que le dan origen a todo el conjunto en términos históricos ${ }^{131}$. Se constata por ejemplo en la sanción del cohecho o compra de votos (el pago, ventaja o promesa al votante para que emita una determinada preferencia o se abstenga de sufragar), en la incorporación -posterior, en cualquier caso, y bajo premisas y razones diversas- de la venta de votos, en los casos adscritos a la idea de fraude (engaño) electoral (votar en más de una ocasión en un mismo proceso electoral o sufragar a pesar de que se carece del derecho a hacerlo) y en las diversas formulaciones o modalidades de obstaculización, presión o coerción ejercidas a efectos de condicionar la opción de voto, pues se trataba de conductas impunes al momento en que se adopta la decisión de tipificarlas como delito electoral ${ }^{132}$. Se advierte asimismo en la incorporación -reciente- de buena parte de los delitos asociados al financiamiento ilegal o irregular de un campaña o elección política ${ }^{133}$, tras la penalización de la "propaganda ilegal"134 y en la

131 De hecho, se puede sostener que en su amplia mayoría la consagración de delitos electorales se orientó a proscribir comportamientos que carecían por completo de relevancia penal, pues se toma como base que en los demás casos la aplicación de la regulación común resulta suficiente. De ahí que presentaren desde siempre una fisonomía equivalente (heterogénea) en tanto orientados a llenar lagunas de impunidad. Véase al respecto Malem (2000), p. 26. En este mismo sentido Betanzos (2012), p. 110 destaca que en la mayoría de los casos las preocupaciones se orientaron a proscribir formas de cohecho (impunes en este campo), desarrollándose en forma paralela a la creación del registro o padrón electoral (en Grecia), que se orienta a los mismos efectos. En los mismos términos Galeano (2011), p. 539.

132 Las diversas formas de cohecho y soborno reclamaron históricamente el compromiso de la función pública siendo por ello ajenas al actuar del votante, que en el ámbito electoral opera como ciudadano $\mathrm{O}$, si se prefiere, como particular. El engaño o fraude y la falsedad -en lo que cabe acá- se vincularon tradicionalmente a las afectaciones patrimoniales, mientras que el tratamiento de la coerción como conducta punible no tiene relevancia autónoma sino hasta que se encuentra bien avanzado el siglo XIX, constituyendo un supuesto que además fue parcial y escasamente acogido en los modelos que siguen la tradición francesa, limitando su sanción en los demás casos a las formas de ejecución violentas. De esta forma resulta claro que todos los ejemplos mencionados resultan impunes si se toma como base la legislación penal común.

133 Sobre la realidad latinoamericana a este respecto véase Fuentes y HeRrera (2014), p. 24.

134 Sobre la reciente incorporación de regulación a este respecto véase PeÑaRANDA (1986), p. 1200. 
sanción de conductas que infringen los deberes de abstención o prescindencia política que pesan sobre ciertas autoridades. De esta forma, resulta casi imposible negar que en cada uno de estos casos las razones que han apoyado las decisiones de incriminación son ajenas -y por ello diversas- a las tenidas en cuenta en la legislación penal común, o, cuando menos, que no son coincidentes con aquellas que justifican la sanción de los comportamientos típicos con los que presentan similitudes.

Esto mismo pareciera que sucede en las demás decisiones de incriminación, esto es, en relación a aquellas cuyo supuesto de base se encuentra incriminado en la regulación penal común bajo un título diverso. Basta ver que los elementos o propiedades que se extraen de las formas de conducta incriminadas como delitos electorales resultan completamente diversos a los que caracterizan a los delitos comunes a los que se asocian, como sucede por ejemplo, con los casos de falsificación o adulteración de resultados y actas de escrutinio, con la sustracción de votos y con las diversas formas de coerción (incluyendo la obstaculización). En efecto, la adulteración de un acta de escrutinio no constituye una forma o modalidad específica de falsedad documental o de engaño en los términos previstos bajo las figuras de falsedad o fraude, sino que se trata de una conducta que pasa a ser (des)valorada en este caso en función de la particular incidencia que detenta en el desarrollo o resultados de un proceso electoral ${ }^{135}$; la sustracción de votos no es sancionada en cuanto acto de apoderamiento material sino a los mismos efectos que recién acabamos de indicar (su incidencia en el escrutinio) al igual como sucede con la coerción violenta ${ }^{136}$. Con ello queda claro que en cada uno de estos casos las respectivas tipologías comunes resultan insuficientes o inocuas para reflejar el significado o sentido que motiva su consideración como delitos electorales. De esta forma se debe sostener que las diferencias van mucho más allá a una cuestión de entidad o gravedad que incida sobre el mismo tipo, clase o forma de infracción, presentando más bien una relación comparativa que no supera con mucho el plano formal, morfológico o, si se prefiere, terminológico ${ }^{137}$.

\footnotetext{
135 Sobre esta base PeñARANDA (1986), pp. 1144-1146, advierte que el uso de la noción de falsedad en el contexto de estos delitos la asimila a cualquier forma de falseamiento de la verdad, noción claramente más amplia que la de uso común en la ley penal general.

136 Se podrá advertir que la pérdida de libertad en la víctima solo es relevante en este caso en cuanto su constatación impide afirmar que el resultado de la votación es fiel reflejo de la voluntad popular, cumpliendo por ello un papel funcional y no medular en el contenido de injusto del delito. Volveremos sobre ello más adelante.

137 A este respecto sirve como claro ejemplo la experiencia reciente que ofrecen los casos asociados a la idea de financiamiento irregular o ilegal de la actividad política (incluyendo las elecciones) de que da cuenta en el foro nacional, pues es por todos conocido que ante la virtual inexistencia de figuras
} 
Con ello todo parece indicar que se trata de infracciones fundadas en razones coincidentes o cuando menos equivalentes a las que subyacen a las demás decisiones de incriminación, de forma que no parece posible realizar distingos sobre su naturaleza o configuración fundado en el dato -formal- de que se trata de figuras centradas en conductas incriminadas en la legislación penal común ${ }^{138}$. Esta conclusión constituye un segundo elemento de juicio que habilita a sostener el carácter erróneo de la aproximación tradicional.

A ello se agrega, como antecedente adicional, que esta forma de aproximación encuentra sus orígenes -y equívocos- en objetivos diversos, mucho más genéricos o superficiales, de carácter estrictamente clasificatorio. En efecto, el casuismo y heterogeneidad de formas de conducta incriminadas bajo este rótulo llevó casi naturalmente a que los diversos análisis hayan concentrado sus esfuerzos -incluso en forma explícita-, en la pretensión de alcanzar algún tipo de orden que favorezca o permita un desarrollo expositivo, tarea que termina influenciando y confundiendo la precisión e identificación de la naturaleza y estructura de cada una de las figuras delictivas, impactando de paso en la precisión del bien jurídico protegido ${ }^{139}$. El recurso al modo o forma de conducta incriminada puede resultar idóneo o útil para aproximarse en forma estructurada o sistemática a un conjunto de delitos, aportando desde este punto de vista a la tarea interpretativa y en la precisión de las correspondientes estructuras típicas de las diversas infracciones. No obstante, las formas o modos comisivos no

típicas destinadas a su sanción específica o particular, los órganos persecutorios han recurrido a la identificación de irregularidades contables o falsedades o adulteraciones tributarias -orientadas a justificar gastos inexistentes- como única vía de sanción penal, a pesar del evidente carácter secundario o marginal que dichas figuras tienen en cuando a la trascendencia social de los hechos juzgados. De ahí que se haya llegado a calificar dicho proceder como algo relativamente torcido o directamente como una tergiversación del sentido de injusto que motiva a penalizar estos casos en particular, confirmando el sentido de lo que hemos señalado en el texto.

138 Resulta por ello incorrecto realizar un distingo en este conjunto separando los delitos comunes agravados de los que se denominan delitos "propiamente electorales" -identificando estos últimos precisamente con aquellas formas delictivas (originarias) que carecen de correlato en la regulación penal común-, pues la categorización pareciera más bien responder a un mismo y único fundamento de respaldo. En el sentido objetado JIMÉNEZ (1994), pp. 25 y 26.

${ }^{139}$ Veremos que dichas propuestas se orientan inicialmente a resolver la problemática que propone la dispersión y el casuismo que caracteriza a este grupo de delitos, pero terminan siendo utilizadas a efectos de extraer elementos de juicio que luego son utilizados para la precisión de sus estructuras típicas, de su contenido de injusto y, por extensión, del referente concreto de su lesividad (o, si se prefiere, el bien jurídico protegido). Con ello, se confunden las razones y criterios propios de una aproximación meramente clasificatoria con pretensiones de sistematización material. Así se explica que la diversidad de formas comisivas que caracterizan a este grupo haya servido de base a efectos diferentes, generando una virtual confusión entre la clasificación de los delitos electorales, su sistemática y su fundamento. 
suelen resultar relevantes para la definición de la naturaleza de las correspondientes infracciones o para la precisión de su contenido de injusto. Así, que el engaño constituya un medio o forma comisiva en el estupro, en la estafa y en la trata de personas, no hace que estas figuras presenten una naturaleza común ni determina por ese solo hecho que se trate de delitos referidos a un mismo objeto de protección. Y lo mismo sucede con el robo, la violación y el chantaje, a pesar de que todas ellas se ejecutan a partir de un acto coercitivo.

Todo lo señalado explica por qué las opiniones se han decantado paulatinamente en favor de una tendencia que se aleja del contenido de injusto asociado tradicionalmente a dichos modos de comisión, ubicando el referente u objeto de protección al que se orienta la creación de estas figuras en torno a aspectos o componentes que son propios del desarrollo de los procesos electorales ${ }^{140}$. Sin embargo, no existe acuerdo en torno a cuál podría ser el contenido preciso de ese bien jurídico en particular pues la heterogeneidad que los caracteriza torna compleja la tarea de identificar un referente en común en algo que vaya más allá de la mera referencia formal al desarrollo del proceso electoral ${ }^{141}$.

\section{Bien jurídico protegido por los delitos electorales}

Quienes consideran mayoritariamente que el bien jurídico protegido en los delitos electorales es el propio "proceso electoral" -lo que resulta casi

\footnotetext{
140 Esta asunción no es un mero formalismo o algo marginal. Basta advertir que resulta indiscutiblemente gravosa la sanción prevista para quien vota en más de una ocasión si se analiza el real riesgo que dicha conducta provoca respecto a los resultados de un proceso electoral en el que intervienen miles de votantes, lo que no sucede si se la interpreta como una conducta que afecta a los caracteres esenciales del derecho a sufragio, entre los que se cuenta la igualdad. Lo propio sucede en los regímenes que no sancionan la venta de votos en tanto se asume que el cohecho electoral se orienta precisamente a la protección de este mismo bien jurídico. Finalmente, parece desproporcionada la correspondiente sanción vinculada a los comportamientos ya señalados si se la compara con las previstas para quienes alteran los registros de un padrón electoral, mesa receptora o acta de escrutinio, pues se trata de casos que presentan un mayor riesgo de afectación de los resultados del recuento de votos, si se considera que el objeto de referencia que justifica su sanción radica en la integralidad del resultado del proceso electoral. Finalmente, debemos destacar que la asociación de la venta de votos o de la doble votación con el derecho a sufragio, Ileva necesariamente a considerarlos como delitos de lesión, mientras que la adscripción del fraude o de la substracción u ocultamiento a la integralidad de los resultados Ileva necesariamente a configurarlos -e interpretarlos- como delitos de peligro, tornando problemáticas las consideraciones recién expuestas sobre proporcionalidad.

141 Dejamos constancia asimismo que en algunas opiniones se advierte una especie de diversificación de referentes diversos asociados en todos los casos al desarrollo o función de los procesos electorales. Al respecto la legislación mexicana, por ejemplo, agrupa estos delitos según si afectan a la libertad de sufragio, a la certeza de los resultados o a la equidad en la contienda electoral (véase al respecto Betanzos (2012), p. 110). Bajo dicho supuesto la coacción electoral lesionaría el derecho de sufragio del elector, mientras que el cohecho electoral afectaría la equidad de la contienda.
} 
intuitivo, pero muy general- sostienen que se trata de una función que detenta el suficiente mérito y entidad para constituir autónomamente un objeto digno de protección penal, en atención al particular rol que las elecciones cumplen en todo régimen democrático ${ }^{142}$. Esta función se extrae del nexo indisoluble y estructural que vincula democracia y representación popular, y que se expresa en la necesidad de que el poder soberano se construya a partir del desarrollo de elecciones libres, participativas e igualitarias, periódicas y universales. Con ello se afirma que "el trasfondo o referente del proceso electoral es directamente la soberanía popular"143, por la sencilla razón de que su ejercicio activo se expresa a partir de la representación popular en todo régimen de gobierno de carácter democrático. De hecho, en algunos contextos y lugares históricos se llegó a considerar que este tipo de infracciones constituían verdaderos atentados contra la propia soberanía ${ }^{144}$, que por ello presentan la mayor relevancia social y gravedad ${ }^{145}$.

Si bien lo dicho constituye una premisa esencial en dicha tesis que resulta difícil de controvertir a los efectos señalados (la asignación de una particular relevancia pública y social a los procesos electorales), no parece que la trascendencia correctamente atribuida al rol que sirven las elecciones populares se pueda trasladar en forma automática a los contenidos que dan forma a un determinado régimen o sistema electoral. Los procesos electorales desarrollan dicha función a partir de una diversidad de elementos y decisiones particulares siendo éstas las que configuran y determinan su contenido propio y particular. En este sentido hay que tener en cuenta que no existe un mismo y único proceso electoral sino diversas modalidades que dan cuenta o reflejan un determinado estado de desarrollo o forma de ejercicio de la representación popular en un

142 En este sentido en este sentido Cruz (2013), p. 5; Orts (1977), p. 285; JIMÉnez (1994), p. 85; MarTí y Muñoz (2008), pp. 2 y 5; Altes (1999), p. 172; Fernández y Ojesto (2007), p. 1020. Con respecto a una parte de las figuras JIMÉNEZ (1994), p. 28.

143 Como indica JIMÉNEZ (1994), p. 1.

${ }^{144}$ Confróntese en JIMÉNEz (1994), p. 3, en particular, en el desarrollo que expone sobre el nexo histórico que vinculó a este grupo de delitos con aquellos que tradicionalmente se regulan para la protección de la soberanía. Asimismo, véase FARALDO (2014), p. 163, quien detalla que la expresión delito electoral fue utilizada en forma histórica con un contenido más amplio que engloba todo atentado a la soberanía (siendo por ello emparentado con delitos como la rebelión, la sedición y otros equivalentes). Implícito en FerNáNDEZ (2008), pp. 442 y 443, quien los identifican como afectaciones internas promovidas desde la autoridad o desde los ciudadanos que por ello se diferencian de las externas -como la subversión-.

145 En Roma el crimen electoral por momentos fue considerado capital como destaca GaLEANO (2011), p. 540. Lo propio sucedió en Grecia, según nos refiere POlanco (2011), p. 1 (incluyendo ambos casos). 
contexto determinado ${ }^{146}$. Este se configura en base a definiciones que dan cuenta de un tipo, clase o forma particular que adopta el correspondiente sistema electoral. Lo relevante de esta precisión -que parece obvia- es que permite advertir que la exclusiva referencia al mencionado proceso constituye una remisión vacía o meramente formal, en tanto son dichos contenidos particulares los que darían forma al núcleo material del correspondiente referente de protección, con total independencia de cuáles fuesen sus características y de su mérito o funcionalidad para los fines que sirve dicha ritualidad ${ }^{147}$. Desde esta perspectiva, se puede objetar a esta tesis que el núcleo que lleva a atribuirle una particular relevancia debiera radicar en un lugar diverso a lo que ofrece su estructura o forma, en tanto pareciera que lo que realmente se desea proteger se encuentra vinculado a la funcionalidad que dicho régimen propone para hacer operativo el ideal que representa la idea de representación popular, en términos que puedan presumir como efectos propios de un régimen democrático ${ }^{148}$.

Sobre bases equivalentes la mayoría de las opiniones concluye -con bastante razón a nuestro juicio- que el contenido relevante de dicho referente de protección no puede radicar en la forma que adoptan las reglas que norman o caracterizan el desarrollo del proceso electoral, sino que necesariamente ha de estar vinculado a los valores (funciones) que "debiese" representar. De esta forma un sector de la doctrina se inclina en favor de la idea de que el contenido de base que justifica la protección penal en estos casos radica de manera específica en ciertas propiedades o principios que debiesen caracterizar a todo proceso electoral, en tanto se las considera como requisitos o condiciones esenciales para el adecuado cumplimiento de su función propia (esto es, canalizar la soberanía popular a través de la representación popular). Lo dicho decanta

\footnotetext{
${ }^{146}$ A este respecto se debe tener en cuenta que son numerosos los sistemas electorales propuestos a través de la historia y que reflejan sus contenidos, con mayor o menor acierto, en las diversas regulaciones. Cada uno ofrece ventajas y desventajas comparativas a los efectos de canalizar la soberanía popular. Sobre la diversidad de sistemas electorales véase Nogueira (2012), p. 806. Sobre los tipos de sistemas o modelos electorales véase NoguelRA (2012), pp. 887-890. Sobre cómo los sistemas impactan en la relación entre representantes y representados, véase Espín (1997), pp. 38 y ss., quien asimismo aborda sus ventajas y desventajas.

147 De hecho, hay que tener en cuenta que lo que se exige acorde al sistema universal de derechos humanos respecto de los sistemas electorales son estándares que se limitan a asegurar que cumpla con su función (adecuación entre participación y resultados), lo que resulta demasiado básico si se lo compara con los contenidos propuestos en el texto. Al respecto, véase Nogueira (2012), p. 806.

${ }^{148}$ En síntesis, el proceso electoral no se valora en cuanto ritualidad u organización procedimental, sino que da cuenta de una función precisa que puede encontrarse bien o mal ejecutada. De ahí que la sola referencia a dicha estructura sea insuficiente para configurar un sustrato idóneo como bien jurídico penal. En este sentido Cruz (2013), pp. 14 y 18. En un sentido equivalente, Bravo y Leal (2011), p. 27.
} 
concretamente en la proposición de la "pureza y transparencia" del proceso electoral149, su "objetividad" o su "integridad"150 o directamente la "confianza o credibilidad" que se puede depositar en el mismo ${ }^{151}$, como contenidos que dan forma al bien jurídico protegido en estos delitos en particular ${ }^{152}$. Esta es la línea que en la actualidad concita el parecer favorable de la mayoría de las opiniones que se ocupan de forma específica del tratamiento de esta cuestión en particular en la literatura ${ }^{153}$.

Ahora bien, más allá del análisis que se puede realizar de dichos caracteres en particular -y que obviamos por razones de espacio y relevancia- se podrá advertir a simple vista la gran dificultad que supone la pretensión de reconocer el contenido propio de un bien jurídico penal, respecto de calificativos o condiciones como las mencionadas. Se trata de aspectos o atributos que presentan un serio problema de concreción, teniendo en cuenta que representan contenidos difusos o indeterminados y que se usan conceptos para representarlos que replican esos mismos caracteres. De esta forma, se trata de características que no reflejan en términos certeros lo que realmente desean representar y proteger y -lo que es más grave- que no dan cuenta en forma precisa del efecto lesivo que se pretende constatar en las diversas tipologías delictivas.

A nuestro juicio, lo que sucede es que las ideas referidas (asociadas a la pureza, transparencia, integralidad u objetividad del proceso electoral) no pretenden dar cuenta de un significado propio en términos lingüísticos o terminológicos, sino que son utilizadas para graficar una imagen diversa e implícita: la necesidad de contar con un proceso electoral ajeno a interferencias que pudiesen poner en tela de juicio el que se han cumplido todas las condiciones necesarias para que la representación política sea lo más próxima a la

\footnotetext{
149 Cruz (2013), p. 14; Peñaranda (1986), p. 1109; Martí y Muñoz (2008), pp. 1 y 2; Altes (1999), p. 172. Equivalente en Fernández y Ojesto (2007), p. 1020. Galeano (2011), p. 543; Polanco (2011), p. 2, destacan que dicha caracterización, a los efectos indicados, se confirma en los fundamentos esgrimidos en términos originarios en el CP francés de 1810, centrado en la "libertad, honestidad y sinceridad del sufragio".

150 En un sentido equivalente o análogo se menciona la "integralidad" o la "pulcritud" de dicho proceso. Al respecto Betanzos (2012), p. 110. A nivel general Romero (2005), p. 117.

151 Se menciona en torno al caso chileno en TORRES (2016), p. 38, como opinión atribuida al ejecutivo en el contexto de la tramitación de la Ley № 20.900 que introduce tipos penales aplicables al financiamiento irregular de procesos electorales.

152 Bravo y LeAL (2011), pp. 19 y 26, aludiendo a diversos aspectos o características en torno a cada figura en las páginas siguientes.

153 Lo destacan en esos términos Betanzos (2012), p. 110; Gálvez y Rubio (2007), p. 116.
} 
voluntad real del cuerpo electora ${ }^{154}$. Lo importante radica en que se trate de un proceso o ritualidad cuyos resultados puedan ser considerados, sin mayores objeciones o dudas, como una auténtica expresión de la soberanía popular, teniendo en cuenta que toda afectación en el proceso electoral representa más bien un peligro para el desarrollo de la función electoral y, con ello, de las instituciones democráticas o republicanas asociadas a la representación popular ${ }^{155}$.

Creemos que esta precisión se confirma a través de la propia literatura de referencia, muchas veces de forma casi inadvertida y al margen de lo que en cada caso se proponga respecto del bien jurídico o la forma en que se dispone su afectación a través de las correspondientes figuras típicas. Así por ejemplo cuando se califica a los delitos electorales como delitos de falsedad, en expresa referencia a los resultados electorales ${ }^{156}$; cuando se menciona la sinceridad del sufragio ${ }^{157}$ como parte del ámbito de protección y, sobre todo, cuando de manera algo liviana se interpretan los delitos electorales como expresiones de corrupción política, considerando que su realización provocaría un efecto corrosivo o distorsionador del sistema electoral y de la representación pública en general.

Ahora bien, lo dicho va mucho más allá de la necesidad que tiene la sociedad de contar con elevados grados de certeza sobre los resultados del proceso electoral, certeza que se sostiene y expresa concretamente sobre su regularidad formal ${ }^{158}$. Dicha perspectiva pasa por alto que el sentido orientador de dicha regularidad $-y$ por ende su sustrato material- lo aporta la necesidad de satisfacer el derecho que tienen todos los individuos a ejercer la cuota de

\footnotetext{
154 Próximos en esta línea Cruz (2013), pp. 3 y 17 y Peñaranda (1986), p. 1144.

155 En este sentido PatiÑo (2012), pp. 38 y 52. Lo relevante es que el nexo entre representación, sufragio y resultados se basa en un proceso electoral transparente y confiable, además de igualitario, secreto, etc. Al respecto véase Nogueira (2012), p. 807. Sobre el nexo básico o fundamental entre representación y democracia, sus problemáticas más fundamentales y su vinculación con la celebración de elecciones libres y periódicas, véase Espín (1997), pp. 29-33. Debemos mencionar sin embargo que se trata de una relación que no está exenta de reparos pues, en términos reales, se basa en supuestos que parecieran desmentir que exista realmente una relación directa entre representantes y representados. Al respecto véase Espín (1997), pp. 33 y ss. Asimismo, véase ReHeren (2016), p. 132, con respecto al rol de los partidos o de la forma que adopta la organización de la actividad política.

156 Al respecto véase Gálvez y RuBıo (2007), p. 6.

157 Véase Betanzos (2012), p. 110.

${ }^{158}$ En este sentido, dicha aproximación parecería confirmar el sentido que subyace a la posición de quienes entienden que el referente preciso de protección recae en los caracteres esenciales del proceso electoral pues, al no ser posible alcanzar dicha certeza sobre una base material, habría que fijar la vista en su integridad o regularidad, expresada -efectivamente- a través de dichos elementos esenciales.
} 
incidencia que les corresponde y detentan en la soberanía popular. Dicha cuota se expresa concretamente en la facultad de participar en los procesos eleccionarios en plena igualdad de condiciones, de forma que la certeza de los resultados y la regularidad de las formas o de la ritualidad del proceso electoral, adquieren su pleno sentido en función del ejercicio igualitario del derecho de sufragio. En relación a ello, que el proceso electoral no sea más que el hito en que se fija formalmente dicha funcionalidad ${ }^{159}$. Así se explica que dichos derechos sean reconocidos como el sustrato que expresa la soberanía y la representación popular, pues, lo esencial en el proceso de gestación de las opiniones que representan o cristalizan la voluntad y la soberanía popular a través de los procesos eleccionarios radica en el acceso de todos los individuos (universalidad) a intervenir en ellos en condiciones equivalentes (igualdad) acorde a las diversas visiones y opiniones presentes en la comunidad (libertad) ${ }^{160}$.

Lo dicho -que constituye de paso el objeto de referencia de cualquier sistema electoral- se puede sintetizar con bastante precisión en la equidad que debe caracterizar a la contienda electoral en tanto expresa el igual derecho de todos los individuos a participar mediante ejercicio del sufragio. Sufragio, igualdad y participación, operan por ello como condicionantes clave a tener en cuenta en la configuración de dicha equidad, regularidad, integralidad o, si se prefiere, directamente, en el desarrollo igualitario del proceso electoral ${ }^{161}$.

Sobre esta base creemos que resulta más atendible el criterio sugerido por quienes sostienen que el bien jurídico protegido en estos delitos es el propio "derecho a sufragio", posición sostenida de forma minoritaria, acotada o parcial,

159 En el mismo sentido Astarloa y SieIRA (2016), p. 135.

160 Sobre el nexo entre este derecho, entendido en clave de participación, y la democracia en la base de todos estos delitos, véase CRuz (2013), p. 2; MuÑoz (1983), p. 459. En referencia al sufragio activo, FARALDO (2014), p. 161.

161 Como indica OrTs (1977), p. 275, el derecho de sufragio y la integralidad del proceso electoral están estrechamente vinculadas (entrelazadas). En el mismo sentido se sostiene que el derecho a sufragio es la base de la legitimación institucional y del poder público (por todos, Noguelra (2012), p. 779). En un sentido equivalente, respecto a la relación entre soberanía, derecho de sufragio y sistema electoral véase Espín (1997), pp. 27 y 28; NogueIRA (2012), pp. 804-811. Hay que tener en cuenta además, que el objeto relevante de todo sistema electoral se mide en función de la satisfacción de la correspondencia que debe existir entre el proceso electoral, el ejercicio del derecho a sufragio a través de él y la fijación de resultados que sean representativos de la voluntad popular. Al respecto Nogueira (2012), pp. 806 y 807. Por todo ello, la diversificación que se propone en el derecho mexicano, por ejemplo, y que distingue los delitos según si afectan la libertad de sufragio, la certeza de los resultados o la equidad en la contienda electoral, es errónea, pues se trata de expresiones que, si bien son más precisas, reflejan a fin de cuentas lo mismo. Con respecto a esto último, véase Betanzos (2012), p. 110. 
para explicar -de preferencia- la sanción prevista para una parte reducida de los comportamientos punibles como delitos electorales. No obstante, no compartimos el contenido que tradicionalmente ha sido atribuido a dicho referente a estos efectos, comúnmente vinculado -en exclusiva- al ejercicio activo del derecho a sufragio o, más precisamente, a la libertad que caracteriza al derecho a voto como garantía individual ${ }^{162}$. Dicha conceptualización pasa por alto que el "sufragio activo y pasivo son aspectos indisolubles de lo mismo"163 y que el núcleo de su consideración como garantía individual radica en el reconocimiento de un derecho o facultad de participación que se vincula de forma directa con el ejercicio de la soberanía, a la representación popular y al proceso de configuración del poder político en una sociedad democrática $^{164}$. De esta forma el contenido del derecho a sufragio se expresa en el derecho que se reconoce a todos los integrantes de una comunidad para participar en las decisiones que son propias del colectivo (a ser co-partícipe en las decisiones públicas) y que se expresa además, de la misma forma, en la posibilidad de intervenir aportando sus preferencias individuales como en aquella que lo habilita a canalizarlas o liderarlas mediante su representación, cuya máxima expresión radica en el ejercicio de un cargo representativo ${ }^{165}$.

La omisión de esta segunda dimensión es precisamente lo que explica -a nuestro juicio- el carácter relativo de su reconocimiento y la parcialidad que ha recibido su apoyo en cuanto bien jurídico a los efectos indicados, cuyo complemento -acorde a su contenido natural y conforme a lo señalado- permite superar dichas deficiencias en forma satisfactoria ${ }^{166}$.

162 Se advierte en Betanzos (2012), p. 110; Polanco (2011), pp. 8 y 9 y también en Muñoz (1983), p. 475 .

163 Muy nítido en Cruz (2013), pp. 2, 3 y 16 y en Rodríguez (2006), pp. 15 y 16. El hecho de que el régimen democrático se estructure a partir de la representación popular implica, en términos gruesos y fundamentales, el igual derecho de todos a ser representante (derecho a participar como alternativa en procesos eleccionarios) y a elegir, en condiciones de igualdad, a quienes lo serán (a través del derecho a sufragio). Los sistemas electorales tienden por ello a satisfacer ambos aspectos de la representatividad a la vez.

164 Cruz (2013), p. 15. Lo vincula también (CRUz (2013), p. 19) a la idea de que "un ciudadano es un voto" dando cuenta de que, de fondo, la referencia al sufragio activo que subyace a dicha afirmación ofrece un contenido más amplio, implícito en dicho ejemplo. En un sentido equivalente, respecto del financiamiento electoral, MAROTO (2015b), p. 227 y ROMERO (2005), p. 117.

165 En un sentido próximo Galeano (2011), p. 544. Asimismo, Espín (1997), p. 122. En el mismo sentido, asociado a la noción de sufragio compuesto (que incluye los aspectos del activo y pasivo), NogueIRA (2012), p. 779.

166 A este respecto conviene tener en cuenta que usualmente se critica que el derecho a sufragio sea efectivamente el bien jurídico propio de estos delitos, por cuanto no logra dar cuenta de una parte importante de los delitos que integran este conjunto en forma paradigmática, lo que se explica 


\section{Toma de postura: El derecho a sufragio (en sentido amplio) como bien jurídico protegido en los delitos electorales. Precisiones, implicancias, límites y consecuencias}

La conceptualización propuesta demanda algunas precisiones que resultan indispensables para una adecuada comprensión de las implicancias que ofrece para la interpretación, valoración y crítica del contenido de los delitos electorales. En primer lugar, hay que tener en cuenta que la exclusiva referencia al derecho a sufragio no es más que un ideal aspiracional, pues la precisión de su contenido específico requiere de una concreta contextualización. En concreto, no es posible su reconocimiento en condiciones naturales ni su ejercicio como propiedad absoluta pues se encuentra condicionado por las características que ofrezca la organización social del poder político. Ello obliga a realizar dos órdenes de precisiones diversas ${ }^{167}$. Por un lado, se trata de un derecho estrechamente vinculado-y, en ese sentido, condicionado- al carácter representativo que define la forma como se determina la configuración y concreción (individualizada) de la soberanía popular en la actualidad. Dicho nexo lleva a atribuirle una doble dimensión, como derecho y función ${ }^{168}$, constituyendo el reflejo o contracara de la necesidad de que en dichos procesos hayan podido intervenir o participar todos y cada uno de los integrantes de la comunidad (universalidad), que lo hagan acorde a sus propias decisiones y motivaciones (libertad) y -sobre manera- que lo hagan en condiciones de igualdad ${ }^{169}$. Por otro lado, se debe tener en cuenta que la materialización de dichos caracteres supone necesariamente la presencia de antinomias (en atención a las inevitables colisiones internas ente dichas propiedades y por

\footnotetext{
precisamente por utilizar una noción acotada a su dimensión activa. Al respecto véase CrUz (2013), pp. 15 y ss.

167 Veremos que no basta con la referencia a su sentido nominal a riesgo de incurrir en equívocos o de arribar a conclusiones fundadas en un análisis que terminará siendo superficial. Lo relevante a fin de cuentas, es que su contenido propio no da cuenta de una facultad que se defina a partir de un contenido estrictamente individual ni se expresa en términos absolutos, más allá de que sea habitual recurrir a dicha forma de comprensión a la hora de utilizar dicho referente.

168 Por todos ZúÑIGa (2009), pp. 362, 365 y 366. En este mismo sentido Galeano (2011), p. 544, quien por ello sostiene que la protección del sufragio (como bien) interesa al ciudadano y al Estado en común.

169 Cruz (2013), pp. 16 y 17. De hecho, se suele considerar que el carácter universal, libre, igualitario, directo y secreto del sufragio expresa propiedades esenciales de su ejercicio (por todos, GálvEZ y Rubio (2007), p. 98). No obstante, hay que tener en cuenta que la reserva o secreto no es más que una exigencia secundaria, que constituye más bien una herramienta auxiliar y de flanqueo destinada a garantizar que un ejercicio en condiciones de libertad reales. Al respecto, por todos, NoguelRA (2012), p. 789. Ello incide en el mérito que puede reclamar su vulneración (la violación del carácter secreto o reservado del voto) de cara a la proscripción penal.
} 
efecto de la titularidad común y colectiva del mismo derecho o facultad), lo que lleva a configurar el desarrollo del proceso electoral en base a reglas de síntesis ${ }^{170}$, que por ello se orientan -solo- a la maximización de sus objetivos y no a su satisfacción real y absoluta ${ }^{171}$. De lo que se trata, por ello, es de alcanzar el óptimo de satisfacción posible de la representación colectiva o popular a través del sufragio, lo que refuerza la idea de que lo esencial radica en que su ejercicio se lleva a cabo bajo condiciones de igualdad (en sentido amplio) o, si se prefiere, equidad ${ }^{172}$.

Lo dicho supone que el derecho que detenta cada individuo para manifestarse a favor de las opciones de organización social que considera más atendibles (o convenientes) o para representarlas por sí mismo puede perfectamente encontrarse limitado en función de la necesidad de que dicho ejercicio, en común, se administre bajo condiciones de igualdad ${ }^{173}$. La clave, por ello, la aporta el reconocimiento de condicionantes materiales y sociales que dificultan o favorecen aleatoriamente su ejercicio en cada caso en particular, de forma que todo acto que en términos originarios pudiese constituir una legítima expresión del sufragio individual, puede perfectamente llegar a ser considerado irregular o ilegítimo en la medida en que suponga un ejercicio material incompatible con el desarrollo general o común del sufragio -activo y pasivo- en condiciones de igualdad ${ }^{174}$. De ahí que lo irregular en estos casos

170 Gálvez y Rubio (2007), p. 104.

171 Como indica Peñaranda (1986), p. 1172, "el derecho a sufragio tiene limitaciones legítimas, asociadas por ejemplo a la edad o a la residencia". La universalidad, el carácter secreto del voto y las demás propiedades mencionadas constituyen caracteres cuyo contenido real solo se puede estructurar en contexto, configurándose a partir de tensiones recíprocas. De ahí que presenten -sin excepciones- limitaciones plenamente justificadas. Así, por ejemplo, la universalidad del sufragio admite excepciones respecto de quienes se considera que no cuentan con la edad suficiente para votar o ser elegido; la representación de comunidades o grupos de electores muchas veces demanda la exigencia de factores de pertenencia (como el domicilio); mientras que se acepta que el secreto del voto se relativice cuando se trata por ejemplo de ciudadanos no videntes. Con ello se debe también descartar la idea de que basta con recurrir a los caracteres esenciales del derecho a sufragio para darle contenido, pues se trata de nociones que se ubican igualmente en el nivel de los principios.

172 Sobre el rol de la igualdad (definitorio) en la configuración del derecho a sufragio, Nogueira (2012), pp. 785 y 786.

173 Resulta por ello impropio caracterizar el objetivo de los sistemas electorales en torno a la pretensión de favorecer la libre y natural expresión de la voluntad individual respecto de cuestiones de interés público, planteamientos que en general radican los objetivos de la proscripción en torno a la protección del derecho (individual) de sufragio activo o en la libertad que debe caracterizar a dicho ejercicio.

174 MuÑoz (1983), p. 471. La incidencia de las diferencias de base presentes en la comunidad económica y política ha sido destacada a este respecto desde antiguo. Sobre ello -con cita de referencia desde los griegos- Galeano (2011), pp. 538 y ss. En el mismo sentido, Bravo y Leal (2011), p. 8. Al 
(lo corrupto) se exprese a través de la noción de interferencia, determinada a partir de su nexo con la idea de exclusión $n^{175}$.

Así, por ejemplo, es un hecho que cada individuo o ciudadano goza -o, cuando menos, debiese gozar- del derecho a manifestarse y actuar a favor de sus propias opiniones con miras a que sean representadas y se vean reflejadas en las decisiones colectivas. Constituye algo connatural al propio ejercicio democrático, sin que al respecto se pueda objetar que dichas opiniones u opciones se ven influenciadas por intereses propios o individuales, a pesar de que pudiesen llegar a ser calificados como mezquinos o que no resulten coincidentes con la idea de bien común ${ }^{176}$. De esta forma, quien tiene, adhiere o participa de ciertas ideas e intereses, goza -en principio- del derecho de organizarse a efectos de su mejor promoción y a potenciar su incidencia en el ámbito de las decisiones colectivas, lo que supone naturalmente el derecho de apoyarlas en la forma que mejor le parezca, incluyendo la asociación, el voto, la propaganda, la representación pública y por supuesto la eventualidad de disponer de aportes económicos (o cuando menos estimables en dinero) y cualquier otro tendiente a favorecer su defensa o promoción ${ }^{177}$. No obstante, de lo que se trata es precisamente de que dichos actos podrían llegar a ser considerados irregulares cuando su desarrollo o ejercicio supone afectar, en los hechos, las condiciones de igualdad que hayan sido dispuestas en los respectivos procedimientos encaminados a formalizar la voluntad popular

respecto, en torno al financiamiento de partidos (y electoral, por extensión), véase MeNDILow (2012), pp. 10 y 11.

175 Mendilow (2012), p. 13. Acerca de esto, es importante reiterar que lo relevante es asegurar un igualitario poder de impacto o influencia y no la plena igualdad de opinión en la toma de las decisiones públicas (asociada al voto de mayoría). Al respecto, Ríos (2012), p. 95.

176 No se puede exigir ni controlar que el libre ejercicio del voto se oriente en favor del fin colectivo (o bien común). Sobre ello, en términos amplios, véase MALEM (2000), p. 26. Así se explica también el que se deba tolerar una oferta de campaña irresponsable, de carácter parcial o que no se oriente por contenidos tributarios del bien común, cuya sanción pública se canaliza, en exclusiva, a través del voto. Así, si un candidato prometiere hipotéticamente regalar a todos los chilenos mayores de 18 años un bono de 100 dólares si resulta electo, no comete delito por esa sola razón, ni siquiera si garantiza formalmente su patrimonio en el sentido indicado o si una pluralidad de electores inclina sus preferencias en atención a dicha oferta. Lo relevante radica en estos casos, en la publicidad de dicha oferta, pues solo si es subrepticia o encubierta podría llegar a constituir un quebrantamiento de las condiciones de igualdad. En su caso, y en forma independiente (por razones diversas), podría llegar a materializar una infracción diversa a los límites previstos para el gasto electoral. Sobre la legitimidad que asiste al interés que pudiesen tener los actores privados en incidir en el desarrollo y definiciones de la política pública. Véase ArGANDOÑa (2001), pp. 13 y ss.

177 En este sentido, el solo hecho de dedicar parte del tiempo en forma gratuita al desarrollo de acciones propias de la actividad política, o el realizar una contribución que es fruto del ejercicio profesional personal (como elaborar o imprimir afiches de publicidad, etc.) participa de este carácter. 
(representativa $)^{178}$, constatación que cumple por ello un papel fundamental para precisar las razones que justifican su prevención, represión y sanción en estos casos en particular. Así se explica por qué los sistemas electorales se suelen estructurar a partir de reglas que en su amplia mayoría buscan establecer restricciones al ejercicio de facultades que forman parte de las condiciones de participación política ${ }^{179}$.

178 Como indican Fuentes y Herrera (2014), p. 4, el tema específico del financiamiento electoral y de partidos se centra en la idea de igualdad de oportunidades. Sobre ello, en general, Olaizola (2014), pp. 174 y ss. Asimismo, García (2007b), p. 68. Conviene precisar -a objeto de evitar dudas- que este no es el único motivo que puede concurrir a estos efectos. En general, el carácter irregular de los actos asociados al financiamiento de la política tiene que ver con la constatación de una incidencia económica en la forma en que se organiza, ejerce o administra el poder político, especialmente aquel que goza de reconocimiento institucional en la administración del Estado, pues introduce un factor de dependencia que pudiese llegar a condicionar su ejercicio en un sentido diverso al que debiese inspirarlo (lo relevante es el "quid pro quo", como indica Olaizola (2014), p. 137 y también VILLORIA (2006), p. 198; García (2007b), p. 73. No obstante, lo dicho permite advertir que ese solo contenido no basta para configurarlo como algo irregular, pues el reconocimiento del derecho a sufragio -entendido en la forma que hemos desarrollado en el texto- hace problemático llegar a asumir que todo aporte o nexo económico puede y debe ser considerado como algo indebido por el solo hecho de existir, teniendo en cuenta que no hace más que canalizar el derecho de opinión y participación política de cada individuo (especialmente cuando se asocia al sufragio). Con ello, la calificación de dichos casos como irregularidad obliga a contar con una razón adicional que, en general, se extrae a partir de la constatación de una desviación del fin (y, con ello, como un acto de corrupción). Pero además también es posible acudir a razones distintas a los mismos efectos. Así, por ejemplo, el hecho de que decisiones públicas deban reflejar el sentir dominante o mayoritario de una determinada comunidad supone una génesis basada en debates explícitos y procedimientos caracterizados por la transparencia y la publicidad (al respecto, VILLORIA (2006), pp. 116-118), pues la legitimidad de quien cumple el rol de representar cada una de las ideas e intereses relevantes de considerar, radica precisamente en el respaldo de quienes se sientan identificados con dichos planteamientos (sobre el papel fundamental de dicha representación, véase García (2007b), p. 76), lo que supone -por definición- una merma en dicho contenido o calificación en caso que la orientación del citado ejercicio se desarrolle al margen de ellos, lo que supone conocerlos (publicidad). Lo expresado aplica plenamente y con mayor razón, respecto de quienes se encuentran encargados de ejecutar estos consensos en la administración del Estado. En dicho contexto, se puede sostener que carece de una condición de legitimidad el financiamiento que es oculto o encubierto. Todo lo anterior, aplica en los mismos términos respecto del desarrollo del proceso electoral. De esta forma, no es correcto asumir que en este ámbito la política y el dinero se muestran como referentes irreconciliables. Al contrario, su regulación (y por ende el reconocimiento de un determinado vinculo saludable), se deja describir como parte fundamental del proceso democrático, precisamente para garantizar un ejercicio y elecciones en condiciones de igualdad. En este sentido MALEM (2000), p. 26 y MuÑOz (1983), p. 472.

179 Lo mencionado confirma que dichas limitaciones, y el sentido de irregularidad o ilegitimidad que sugieren, se estructuran con total independencia de la legitimidad de origen que puedan reclamar las facultades y derechos que resultan afectados o constreñidos a través de ellas. Así, quien cuenta con un importante patrimonio y quisiera ponerlo a disposición de sus ideales representados tras una opción plebiscitaria, partidista o tras el lineamiento que respalda un candidato en particular, verá limitadas sus auténticas y legítimas pretensiones políticas a fin de favorecer las posibilidades 
Con ello es posible anticipar que el sentido del carácter injusto de este grupo de delitos, en particular radica exclusivamente en la vulneración de los límites dispuestos en favor de las necesarias condiciones de igualdad que deben caracterizar los derechos de participación comprometidos tras el reconocimiento asociado al ejercicio del derecho de sufragio, contenido común a tales figuras que no sólo permite identificar un referente único que habilita a concederles relevancia autónoma (en cuanto delitos electorales), sino que también permite identificar a su respecto una estructura o modo de afectación (igualmente) común. Con ello, se trata de un contenido que necesariamente ofrece rendimiento para una adecuada interpretación y crítica de las correspondientes tipologías, aportando al mismo tiempo en la orientación que debiese caracterizar a las correspondientes definiciones político-criminales del legislador. Sobre esa base, procuraremos ocupar el limitado espacio que nos resta para finalizar la presente contribución dando cuenta grosso modo de las principales implicancias dogmáticas que se extraen de dicha definición, acompañado de una propuesta de tipificación alternativa (orientada a superar el casuismo) que se estructura a partir de los mismos pilares de base, finalizando con las consecuencias que dicho tratamiento propone en el plano concursal y en su consideración habitual como actos de corrupción.

\section{Implicancias dogmáticas y propuesta políticocriminal}

Lo primero a tener en cuenta es que la dispar fisonomía que ha caracterizado a la tipificación de esta constelación de delitos (que incluye formas de coacción, falsedad, engaño, adulteración de cuentas, apropiación, abuso de posición de dominio, alteración de registros, violación de reserva, violencia y -por supuesto- modalidades que califican como actos de corrupción, en especial, la que es propia del cohecho), constituye de hecho un factor distractivo a los efectos de la determinación de las propiedades relevantes de valorar en cuanto delito electoral. El que se haya centralizado en estas modalidades la atención, ha dificultado advertir que lo esencial radica en una característica o propiedad diversa -común a todas las formulaciones-consistente en que se trata de formas de comportamiento que resultan funcionales para introducir

de participación de los demás ideales, a pesar de que nadie podría discutir que ese individuo goza de pleno derecho a hacer lo que le venga en gana con su dinero. De ahí que se las llegue a calificar como limitaciones constitucionales a la libertad de expresión, justificadas en base a la necesaria pureza que debe caracterizar a los procesos electorales. Al respecto véase MuÑoz (1983), p. 472 y Rodríguez (2006), p. 40. Sobre esta misma base se apoyan los deberes de prescindencia o abstención que emanan de determinadas funciones públicas, a pesar de que quienes las ejercen también debiesen gozar del derecho de manifestar su apoyo o adherencia a las opciones que les resulten más razonables. 
factores disruptivos en la dinámica bajo la cual se configura del poder político representativo. Lo relevante, es que interfiere o afecta el ejercicio igualitario del derecho a sufragio ${ }^{180}$, pues su ejecución impide afirmar con certeza cuáles son los auténticos resultados del proceso electoral, habilitando a que puedan llegar a ser cuestionados como expresión fidedigna de la soberanía popular ${ }^{181}$. Con ello, el que se llegue a constatar que alguien ha adulterado el padrón electoral, que algún votante ha sido incorporado en el padrón en un lugar diverso al que le corresponde, que alguien votó motivado por una amenaza o en consideración a un pago o beneficio personal o, finalmente, que un elector no pudo concurrir a la urna el día de la elección producto de una manifestación, desorden o porque la mesa no se llegó a constituir con ese objetivo, constituyen hitos que desde esa perspectiva afectan la credibilidad de los resultados plasmados en el correspondiente escrutinio, incidiendo de esa forma en la posición de todas las personas e ideas que pudiesen haber sido preteridas o minusvaloradas y, en la percepción sobre el mérito y legitimidad de quienes aparecen favorecidos en dichos resultados. Constituye por ello una afectación relevante para los intereses y derechos de quienes han intervenido como votantes, para todos aquellos que respaldan la opción de los candidatos u opciones que han sido preteridas y también para la investidura o respaldo de los representantes u opciones que resultan elegidos o aclamados, de forma que es posible advertir que su ejecución materializa incidencias generales, colectivas o, si se prefiere, de carácter supraindividual ${ }^{182}$.

Con ello, la conceptualización del derecho a sufragio que se propone y defiende a efectos de su protección penal, no puede ser entendida como la propia de un referente personal, subjetivo o de una garantía individual, sino que refleja su sentido de valor social o colectivo que representa el derecho reconocido a todos y cada uno de los miembros de la comunidad (a la vez) para intervenir en condiciones de igualdad en la configuración de las decisiones

180 MuÑOz (1983), p. 479, con carácter general (si bien lo menciona a propósito del análisis del mérito de incriminación de las formas de falsedad que inciden en el curso del proceso electoral). En el mismo sentido en torno a dichas modalidades delictivas JiménEz (1994), p. 40. Se puede constatar asimismo en las formas de conducta que se reconocen como modalidades históricas a estos efectos (violencia, coerción, corrupción y fraude), conforme indica GaLeANo (2011), p. 543.

181 De forma precisa su efecto propio consiste en debilitar la afirmación de que el escrutinio refleja el conjunto o sumatoria de las voluntades presentes en la comunidad. En un sentido equivalente LEHOUCQ (2007), p. 27.

182 De conformidad con lo sostenido, los delitos electorales se configuran como delitos de lesión, teniendo en cuenta las particularidades que muestran dichas fórmulas en su aplicación sobre bienes jurídicos de carácter colectivo. Al respecto, por todos, Corcor (1999), pp. 219-224. Asimismo, en el derecho chileno, HeRnÁndez (2016), pp. 173-177. 
públicas ${ }^{183}$. Dicho efecto se puede llegar a provocar con total independencia de la incidencia o alteración de la correspondiente opción electiva que el respectivo destinatario pretendía favorecer con su voto, o de la provocación de una concreta brecha entre la soberanía representativa real o efectiva y el resultado del proceso electoral. El que dichos efectos se desarrollen al margen de la afectación que su ejecución pudiese suponer para el ejercicio del sufragio de uno o más electores o "elegibles" (activo o pasivo), habilita a sostener que es posible valorar esta eventualidad al margen del reconocimiento del correspondiente delito electoral. Es así como se debe reconocer el correspondiente concurso de delitos respecto de quien coacciona a otro con violencia para que vote en un determinado sentido (si dicha opción es diversa a su voluntad real) pues, además del correspondiente delito electoral, se podrá constatar una concreta afectación de la libertad de decisión del votante, cosa que no ocurre en las hipótesis en que el cohecho electoral es aceptado voluntariamente por el correspondiente sobornado.

Se trata de una acotación que además aporta un criterio medular a la hora de adoptar definiciones penológicas asociadas a su tipificación y sanción, en tanto dicha determinación resulta esencial para precisar el desvalor y lesividad de las correspondientes figuras. Basta tener en cuenta que la incidencia irregular sobre el ejercicio activo del sufragio de un votante constituye un acto plenamente relevante en cuanto interferencia sobre el proceso electoral -tanto como si se lo analiza desde el punto de vista de su derecho individual (al sufragio)-, pero resulta casi inocuo si se valora a partir de su incidencia en el escrutinio (se trata solo de un voto en un universo compuesto por millones). De esta forma es posible advertir una lesión relevante tras el comportamiento de quién vota dos o más veces en una misma elección a favor de un candidato que obtiene una mayoría absolutamente aplastante (contexto en el que su aporte resulta irrelevante en atención a dicho resultado), en aquellos casos en que se impide la votación de un local completo de votación que sea reconocido como representativo de las condiciones socioculturales y económicas del país, como también tras la oferta, promesa o dádiva (cohecho) que es aceptada por el votante y que sin embargo no logra llegar a modificar la real

\footnotetext{
183 Próximo Betanzos (2012), p. 97 quien entiende que, si bien se trata del ejercicio de un proceso decisorio de carácter individual, éste se desenvuelve en el contexto social de un Estado. En la misma línea De Urbano (2011), p. 5, sostiene que "lo relevante no son las personas sino el sistema". Sobre el tránsito de un estadio propio del reconocimiento individual a la colectivización véase GuZMáN (2017), pp. 172 y ss. Dejamos constancia de una observación recibida de parte del Prof. Jaime Couso a este respecto, quien destacó la dificultad de compatibilizar la idea de derecho al sufragio (casi por definición, individual), con la naturaleza más bien colectiva que hemos propuesto para este contenido.
} 
preferencia que el sobornado manifiesta en el acto eleccionario ${ }^{184}$, pues en todos esos casos es posible cuestionar que los resultados del proceso electoral sean el fruto de un proceso regular, revestido de las correspondientes reglas y garantías de igualdad ${ }^{185}$.

Con ello también, resulta interesante advertir que el criterio propuesto relativiza la relevancia que cabe asignar a la concreta incidencia que las conductas punibles pudiesen tener en los resultados objetivos del proceso electoral, pues no se trata de un efecto determinante para las decisiones asociadas a punibilidad. Su eventual constatación puede llegar a ser considerada como un indicativo complementario de gravedad a ser valorado en el ámbito de la determinación de la pena ${ }^{186}$. Sobre esta base, entendemos que resulta incorrecta la habitual costumbre de calificar a estas figuras como delitos de tendencia, bajo el entendido de que la sanción está prevista aun cuanto no se obtenga la finalidad que los motiva ${ }^{187}$, supuesto que habilita erróneamente a reclamar la concurrencia de particulares móviles o a modificar el contenido de referencia del dolo, todo ello, al margen o con independencia de las exigencias plasmadas en las correspondientes descripciones legales. Y también, se debe descartar que se trate de delitos que sancionan conductas previas a la lesión, con similares efectos y por las mismas razones ${ }^{188}$.

Ahora bien, lo dicho hasta el momento lleva además a descartar la idea de que toda conducta que materialice una incidencia irregular en el desarrollo del proceso electoral, admita ser considerada por ese solo hecho como una (eventual) hipótesis punible, pues solo aquellas que sean idóneas para provocar un riesgo como el señalado podrían llegar a ser consideradas para llegar a

\footnotetext{
184 En un sentido análogo, MUÑOz (1983), p. 476.

185 En el mismo sentido, LeHOucQ (2007), p. 23, (lo asocia directamente al efecto sobre la credibilidad de los procesos electorales, en LeHOucQ (2007), p. 27. Hay que tener en cuenta además que en la mayoría de los casos resulta virtualmente imposible realizar un contraste entre los resultados alcanzados en una determinada elección y aquellos que se podrían haber esperado al margen de cualquier incidencia de carácter irregular.

186 De ahí que sea posible que el legislador utilice dicho presupuesto a efectos de regular consecuencias específicas en base a reglas legales de determinación de la pena, o que se delegue su consideración al proceso de individualización (en nuestro derecho, en cuanto extensión del mal causado, conforme dispone el artículo 69 del Código Penal). Según el caso, esta consideración de mayor gravedad se podrá llegar a fundar en la propia interferencia sobre el proceso electoral (cuando provoca una mayor percepción de ilegitimidad en el proceso) o en la eventual afectación de otros intereses relevantes (asociados, individualmente, al sufragio activo o pasivo), destacando aquellos casos en que los caracteres de las conductas ejecutadas (p. ej. su masividad) pueden llegar a suponer una alteración efectiva de los resultados del escrutinio.

187 En este sentido Muñoz (1983), p. 467; Peñaranda (1986), pp. 1224 y 1225.

188 Al respecto véase MuÑoz (1983), p. 469.
} 
fundar una incriminación penal ${ }^{189}$. Así, se debiera descartar en nuestro derecho el acierto de la reciente incorporación de supuestos asociados a la obtención indebida de fondos públicos asociados al financiamiento del gasto electoral o la sustracción de fondos de campaña y en la vulneración de los deberes de reserva asociados al gasto electoral, al margen de su eventual sanción como supuestos de administración desleal, fraude de subvenciones, infracción de deberes o actos de falsedad. En todos estos casos se trata de conductas que alteran el desarrollo regular del proceso electoral, sin que a pesar de ello incidan en modo alguno en un ejercicio igualitario del derecho a sufragio ${ }^{190}$.

Esta acotación permite además tomar postura sobre el controvertido asunto de la penalización del votante en los casos de cohecho electoral, al margen de las argumentaciones que caracterizan a la discusión tradicional ${ }^{191}$. En efecto, a pesar de que se debe descartar su consideración como víctima del delito y que parece claro que su contribución en dichos supuestos incide en la producción de los efectos indeseados que se desean proscribir (contribuye a relativizar los resultados del escrutinio), no es posible sostener que en dichos casos se materialice una infracción a las ya señaladas condiciones de igualdad, lo que lleva necesariamente a descartar cualquier pretensión orientada a su punibilidad. El voto no será más que el mismo y único, ni se podrá afirmar que no haya sido su propia opción en particular.

Conviene precisar además, que es esta exigencia la que lleva a asignar relevancia al contexto que ofrece el proceso electoral en el marco de estos delitos, proponiendo una consideración funcional que lleva a desechar la idea de que se trate de una condicionante de carácter espacio-temporal (como se sugiere

189 En el mismo sentido Olaizola (2015), p. 193. Lo dicho confirma la insuficiencia de considerar que el bien jurídico se estructura a partir de la sola constatación de cualquier tipo de afectación del proceso electoral o de ciertos caracteres genéricos aplicables sobre el mismo (como su regularidad o integralidad).

190 En el mismo sentido Olaizola (2014), pp. 175 y 177, quien por ello entiende que no hay razón alguna que lleve a distinguir los tipos previstos de financiación electoral respecto a los tipos comunes. En el mismo sentido ROMERo (2005), pp. 158 y ss., a pesar de que luego se manifiesta contrario (ROMERO (2005), p. 180) en caso en que el respectivo acto (la sustracción de dineros, por ejemplo) pueda generar anomalías en la paridad que debe caracterizar al proceso electoral.

191 Las opiniones históricas rechazan su penalización en tanto se identifica como víctima en dichas hipótesis pues se entiende que lo protegido coincide con su libertad eleccionaria (derecho de sufragio activo). Se destaca como doctrina uniforme en Jiménez (1994), p. 64, nota 176; en el mismo sentido Gálvez y Rubio (2007), pp. 121 y 122, y PeÑARANDA (1986), p. 1223. En tiempos más recientes prima la idea de que su contribución igualmente afecta al desarrollo y resultados del proceso electoral lo que permite calificarlo como un verdadero autor de la correspondiente infracción o, en su caso, como partícipe de la misma, por la posibilidad de sostener que la aceptación de las dádivas o beneficios supone concurrencia de su voluntad. Al respecto, véase GALEANO (2011), p. 548. Sobre el tema en general véase GuZMán (2017), pp. 180 y ss.; MuÑoz (1983), p. 475; RodríGUEZ (1995), p. 1242. 
por parte de la doctrina tradicional). Los delitos electorales no constituyen infracciones asociadas "al día de las elecciones", al período de campaña o a los hitos materiales a través de los cuales se configura del padrón electoral, sino infracciones que inciden en las condiciones de ejercicio del sufragio. Con ello es perfectamente posible llegar a identificar la comisión de conductas delictivas comunes durante el desarrollo del acto eleccionario, como también configurar delitos electorales que se basan en comportamientos ejecutados en contextos diversos ${ }^{192}$.

Lo dicho supone además tener que reconocer que existe una estrecha relación entre los contenidos de las correspondientes infracciones y las reglas dispuestas para favorecer la regularidad o equilibrio en desarrollo del proceso electoral, con independencia de que se expresen a través de instancias de privilegio (orientados por razones de discriminación positiva ${ }^{193}$ ) o a través de contenidos de carácter limitativo. Desde esta perspectiva, por ejemplo, no es posible reclamar protección penal respecto de aquellos ámbitos que carecen de reconocimiento formal (como sucede con quienes no gozan del reconocimiento de la titularidad o del ejercicio del sufragio activo o pasivo), mientras que solo es posible llegar identificar infracciones punibles asociadas al financiamiento electoral en la medida que la legislación considere límites reglados orientados a reducir las condiciones de desigualdad naturales ${ }^{194}$. Sobre esta base se sostiene -con bastante razón- que la protección del sufragio "se arti-

192 GÁlvez y Rubıo (2007), p. 5.

193 En este grupo se suele considerar la situación de quienes presentan problemas de desplazamiento asociados a alguna incapacidad física o a la distancia física de los lugares de votación; la de quienes presentan limitaciones visuales o de alfabetización y la de quienes se encuentran sujetos a regímenes institucionalizados por decisión de la autoridad (como las cárceles). Respecto a estas situaciones -considerablemente menos tratadas en el marco de los delitos electorales- véase con carácter general GÁlvez y RUBıo (2007). La particularidad de estos contextos y reglas es que habilitan a identificar formas de afectación igualmente particulares o excepcionales, aportando un contexto que hace plausible el uso de aproximaciones de corte casuístico. En este sentido Gálvez y RuBıO (2007), p. 104. Así, por ejemplo, el que la votación de un no vidente admita una excepción a la reserva o secreto que cabe reconocer a dicho ejercicio, ofrece un contexto especial que resulta idóneo para advertir potenciales intromisiones indebidas. Para una parte de la doctrina resulta más gravosa la ejecución de delitos en estos casos, en consideración a que se trata de situaciones fundadas en una particular condición de vulnerabilidad. Al respecto véase GálvEZ y RuBıO (2007), pp. 111 y 112. Dicha consideración supondría una aproximación individualista que por ello resulta ajena a la conceptualización que hemos sostenido.

194 Dicho en términos sencillos: si un determinado Estado no garantiza el igual acceso a los procesos electorales mediante un sistema de financiamiento que tienda a favorecer condiciones de igualdad en todos los postulantes, poco es lo que puede hacer el derecho penal o el derecho infraccional en general (incluyendo al administrativo), frente a un contenido que el propio ordenamiento no protege. De más está señalar que ese es precisamente el objeto de dichas regulaciones. Al respecto, García (2007b), p. 70. 
cula a través de las leyes electorales"195, pues únicamente resulta posible dar protección al derecho de sufragio dentro de los límites que ofrece y garantiza a dicho respecto el correspondiente sistema electoral ${ }^{196}$. De esta forma, se debe reconocer que su contenido propio se integra preferentemente a partir de aquel que se propone en dichas disposiciones, lo que explica por qué en este campo resulta casi connatural el uso de leyes penales en blanco ${ }^{197}$ y por qué resulta conveniente que su tratamiento se incluya en la propia regulación extra codificada, radicada en el contexto que proponen las correspondientes leyes que regulan el contenido y ritualidad de los procesos electorales u otros vinculados al ejercicio de la actividad política ${ }^{198}$.

Los contenidos expuestos hasta el momento ofrecen además dos ventajas comparativas: primero, el que aporta un criterio que permite delimitar el campo que separa las conductas que tienen mérito para ser declaradas punibles de aquellas que son tratadas en base al derecho administrativo sancionador ${ }^{199} \mathrm{y}$, segundo, el que ofrece argumentos para favorecer el uso de una técnica regulativa orientada por la objetivización de los comportamientos punibles -lo que no supone en caso alguno "casuismo"- alternativa que se favorece además por la relación determinante que vincula al ejercicio del derecho a sufragio (en sentido amplio), con los contenidos específicos que ofrece cada regulación

195 CRUz (2013), p. 24.

196 De esta forma las referencias no se identifican con un determinado proceso o procedimiento electoral, sino con las condicionantes asociadas a razones de participación e igualdad que proponga. Su núcleo lo aporta por ello el contenido que ofrecen las reglas orientadas a establecer condiciones para garantizar un ejercicio igualitario del sufragio (activo y pasivo) y aquellas que tienden a limitar su ejercicio natural con este mismo objetivo. En este contexto parece evidente que un modelo electoral rígido -altamente proteccionista- ofrecerá mayores espacios para identificar una infracción, mientras que un procedimiento electoral menos riguroso o igualitario dará lugar a una menor necesidad de protección. Así, por ejemplo, es posible asignar relevancia al acto consistente en falsear el domicilio del votante o candidato cuando las reglas electorales exigen alguna vinculación territorial para ser elector o representante, fundados en la idea de que los cargos deben ser ejercidos por individuos que pertenezcan a ciertas comunidades y que solo sus integrantes pueden intervenir en su designación, lo que propone una exigencia (material) que condiciona el ejercicio del derecho de sufragio.

197 Por todos Jiménez (1994), pp. 55 y 56. En este sentido Altes (1999), pp. 167 y 168; Patiño (2012), pp. 28 y 29 -si bien opina en contra de esa opción- y Gálvez y RuBIO (2007), p. 30.

198 En este sentido (en favor de su consideración en leyes especiales), por todos, Gálvez y RuBıO (2007), p. 30. Se argumenta además en esta misma línea que el derecho electoral se estructura a través de contenidos altamente específicos, cuyo dominio sistemático o de contexto resulta indispensable para una adecuada comprensión e interpretación de las diversas reglas que lo componen, incluyendo al régimen de infracciones administrativas y, por supuesto, a las que revisten carácter penal. Al respecto PATIÑO (2012), p. 9.

199 Al respecto FeRnández y Ojesto (2007), p. 1071, quienes destacan, en forma específica, que "la sola referencia a la afectación del proceso electoral resulta a estos efectos inocua". 
electoral ${ }^{200}$ y que confirma la idea de que es necesario estructurar una reformulación más o menos importante al contenido de los comportamientos que actualmente son tipificados bajo el rótulo de delitos electorales.

Bajo este contexto, toda reformulación debiera estar orientada a alcanzar una profunda simplificación en la regulación, lo que presupone la supresión de una buena cantidad de infracciones actualmente consideradas. Ello, pues es posible regular hipótesis comisivas más generales (de carácter más comprensivo) o por el simple hecho de que en muchas de ellas no se advierten el compromiso de los contenidos que habilitan o aconsejan su proscripción bajo este rotulo. Por ello, entendemos que se justifica una regulación caracterizada en la siguiente forma:

1. Considerar inicialmente una hipótesis básica de fraude electoral a través de la cual se proscriban los contenidos tradicionales a los que se asocia dicha terminología (relativa a los actos que representan un ejercicio individual abusivo o reiterado del voto $^{201}$ ), considerando además una penalidad agravada para los casos en que su comisión se favorezca mediante el abuso de una función pública adscrita al desarrollo del proceso electoral ${ }^{202}$.

\footnotetext{
200 Se suele justificar el uso de este tipo de fórmulas -y también el propio uso de fórmulas detallistas o el casuismo- en la dificultad que plantea la identificación precisa de los elementos que habilitan a fundar la irregularidad en este tipo de comportamientos. Así sucede, por ejemplo, cuando se analizan las conductas de abuso de poder que podrían llegar a ser calificadas como actos de intervencionismo electoral o cuando se revisan qué casos de apoyo partidista puede llegar a ser interpretado como un acto de financiamiento de campaña (sobre esto último, véase MAROTO (2015b), pp. 173 y ss.). Lo realmente importante a nuestro juicio es que dicha determinación se nutre de las propias reglas que las fijan pautas objetivas de conducta, pues son éstas las que marcan los límites que separan lo irregular de lo ilícito y, con ello, lo tolerable respecto a lo que no lo es. En concreto, la vulneración de dichos límites no solo supone una infracción formal sino la ejecución de un de comportamiento que afecta al desarrollo regular de un proceso electoral, lo que supone una particular asignación de gravedad. Con ello se debe descartar la pretensión de considerar criterios adicionales -filtros de punibilidad- asociados a la diversa entidad o gravedad que pudiese revestir la correspondiente infracción, pues supone desconocer que dicha calificación procede en todos los supuestos. Al respecto destaca el que históricamente se consideró, por ejemplo, que en los casos de cohecho el interés económico debiese ser relevante, lo que favorece la impunidad de las pequeñas donaciones o regalos y, en otros ámbitos, lo que se pueda considerar como aporte de campaña o propaganda electoral (sin perjuicio de la ilicitud administrativa). Para este punto, véase MuÑOz (1983), p. 476. Asimismo, PeÑARANDA (1986), p. 1222, quien alude fundamentalmente a razones de adecuación social a los mismos efectos. En el mismo sentido, Jiménez (1994), p. 64. En contra, en el sentido sostenido por nosotros, RODRíGUEZ (1995), p. 1242 y TORRES (2016), pp. 34 y ss., en relación a la regulación chilena del financiamiento electoral (en términos críticos).
}

${ }^{201}$ Gálvez y Rubıo (2007), pp. 117-121. Se incluye también el caso de doble inscripción; el ocultar un voto, cambiar la elección impuesta o alterar el tipo de elección.

202 Dicho supuesto incluiría por ello la sanción a quien vote en una elección más de una vez (art. 136 Ley $\mathrm{N}^{\circ}$ 18.700); la prevista para quien suplante a un elector o lleve su nombre para sustituirlo (art. 136 Ley $N^{\circ} 18.700$ ); la aplicable al miembro de mesas receptoras que admita el sufragio de personas que 
2. Se debiera penalizar además -como fraude agravado- toda forma de adulteración de los registros necesarios para el desarrollo del proceso electoral (incluyendo la sustracción, destrucción y la falsedad), pues se trata de formas de alteración que provocan efectos de carácter masivo, relativas a la participación de varios electores o votos ${ }^{203}$. Se debe considerar asimismo una mayor gravedad para el caso en que interviene un funcionario, hipótesis que también amerita la previsión de infracciones imprudentes.

3. Del mismo modo, se debiese tipificar el delito de cohecho electoral; la vulneración de la reserva del voto por parte de terceros y la coacción electoral ${ }^{204}$, considerando en este último caso una formulación amplia para el respectivo medio comisivo (cualquiera sea la forma de impedir o compeler al ejercicio del voto ${ }^{205}$. En este último caso se debieran además regular dos formas calificadas adicionales: las primeras, fundadas en el mayor desvalor atribuible a ciertos medios comisivos en particular, que incluya la violencia, la intimidación, la amenaza, la provocación de desórdenes públicos y el abu-

no figuren en el padrón o que no exhiban su cédula de identidad (art. 132 Ley Nº 18.700), de quienes hagan una marca o señal en una cédula con el objeto de preconstituir una causal para anular el voto (art. 132 Ley $\mathrm{N}^{0}$ 18.700) o de quienes nieguen el sufragio a electores habilitados o que impidan, obstaculicen o dificulten el sufragio de personas con discapacidad (art. 132 Ley $N^{\circ}$ 18.700).

203 Estos supuestos incluyen el caso de quienes omitan, alteren o destruyan los resultados de un proceso electoral siendo responsables del ingreso informático de los datos (art. 135 Ley No 18.700); el de quienes confeccionan actas de escrutinio de mesas que no funcionaron (art. 136 Ley $\mathrm{N}^{\circ} 18.700$ ); el de quien falsifica, sustrae, oculta o destruye el padrón de una mesa, el acta de escrutinio o la cédula electoral (art. 136 Ley No 18.700); alteran la información del registro electoral; padrón electoral; padrón de mesas receptoras de sufragio; nóminas de inhabilitados o cualquier otro dato que sirva para conformar o actualizar el registro electoral (art. 54 Ley $\mathrm{N}^{0}$ 18.556); extravíen, dolosa o imprudentemente, documentos, solicitudes de cambio de domicilio o avecindamiento o destruyan datos computacionales de antecedentes del registro o padrón electoral o del padrón de mesas receptoras de sufragio (art. 56 Ley $N^{0}$ 18.556); de quienes suplanten a una persona en una solicitud de cambio de domicilio o avecindamiento u ocultaren, sustrajeren o destruyeren solicitudes de cambio de domicilio, de avecindamiento o sus antecedentes de respaldo (art. 53 Ley $N^{\circ} 18.556$ ) y la aplicable a quienes modifiquen el domicilio electoral informado por un elector -o cuando lo hagan al renovar cédula de identidad- (art. 54 Ley $\mathrm{N}^{0}$ 18.556).

204 Sobre el nexo entre estas formulaciones, véase PeÑaRANDA (1986), p. 1218.

205 Esta formulación debiese comprender el caso previsto en la actualidad para quien solicita votos por paga, dádiva o promesa o cohecha de cualquier forma a un elector (art. 137 inc. $1^{\circ}$ Ley $N^{\circ} 18.700$ ) y la sanción al miembro de una mesa receptora que haga una marca o señal en una cédula con el objeto de violar el secreto del voto (art. 132 Ley $N^{0}$ 18.700). Hay que tener en cuenta que muchas de las regulaciones omiten la consideración de los actos coactivos u otros similares orientados a impedir el voto individual, cuyo contenido o efecto es equivalente al que se orienta a obtener una determinada orientación o preferencia en el ejercicio activo del voto. A este respecto véase Betanzos (2012), pp. 118-120; AstARLOA y SiEIRA (2016), p. 188 (en cuanto la abstención constituye una opción equivalente al ejercicio del voto a favor de una opción individual). Asimismo, en cuanto a las incidencias que buscan condicionar un voto en blanco o nulo, véase MuÑoz (1983), p. 476. 
so funcionario; mientras que las segundas debiesen dar cuenta de aquellos casos en que se provoca una afectación masiva, abarcando aquellos en que la conducta recae sobre locales, el escrutinio o ciertas funciones electorales centrales para el desarrollo del proceso. Entre ellas se debieran incluir -en forma equiparada- los casos de suplantación (en cuanto impidan el ejercicio de dichas funciones) y de abandono de funciones ${ }^{206}$.

Se podrá advertir que la sanción propuesta para los desórdenes públicos es considerada en función de la regularidad del desarrollo del proceso electoral, en cuanto constituye una interferencia que pudiese afectar el ejercicio activo del voto o de las funciones asociadas a su recepción y al escrutinio. De ahí que se la deba asimilar a las formas específicas de coerción, pues es un modo de obstaculizar el voto, su recepción o el escrutinio ${ }^{207}$. Y lo propio sucede con la abstención, falta de ejercicio o abandono de funciones pues el sentido de la incriminación de dichos incumplimientos se vincula estrictamente al riesgo que su ejecución supone para el ejercicio del sufragio o para el escrutinio, afectando así la integralidad o regularidad del proceso y, por extensión, la regularidad del resultado del escrutinio ${ }^{208}$, por ello, constituyendo también actos de obstaculización ${ }^{209}$.

\footnotetext{
${ }^{206}$ Ello comprende la sanción a quien incide en el voto de otro o impida sufragar por violencia, amenaza, privación de cédula de identidad o equivalente (art. 136 Ley No 18.700) y la de quienes perturbaren el orden en lugar en que funcione una Junta, mesa receptora o colegio escrutador, con el fin de impedir su funcionamiento (art. 131 Ley № 18.700), además de los "desórdenes públicos" y "tenencia de armas", y la aplicable al miembro de mesas receptoras que cambien el lugar previsto para su funcionamiento (art. 132 Ley $N^{\circ}$ 18.700), que impidan la presencia de algún miembro de la mesa o apoderado (art. 132 Ley $\mathrm{N}^{0}$ 18.700) o que suspendan abusivamente la recepción de votos o del escrutinio (art. 132 Ley $\mathrm{N}^{0}$ 18.700). Además, el caso de quien impide ejercer funciones a un miembro de la Junta Electoral o de una mesa receptora de sufragios o de un colegio escrutador o de un delegado ante el colegio escrutador (art. 131 Ley $N^{0}$ 18.700); el del miembro de mesa receptora, junta electoral o colegio escrutador que funcionen o adopte acuerdos sin quorum o sesione en lugares u horas diversas a las autorizadas en la ley (art. 133 Ley № 18.700), del delegado de junta electoral que no constituye las mesas conforme a procedimiento legal; que le impide a un apoderado ejercer sus funciones, les retira las carpetas o credenciales o los expulsa del local (art. 134 bis Ley $\mathrm{N}^{\circ}$ 18.700); de quien suplanta a un delegado de junta electoral o a un miembro de una mesa o colegio escrutador (art. 136 Ley $\mathrm{N}^{\circ}$ 18.700); el del miembro de mesas receptoras que se retire injustificadamente antes del cierre de la mesa (art. 132 Ley $N^{0} 18.700$ ); del jefe de fuerzas de orden que sea requerido por autoridad competente y que no preste la cooperación requerida (art. 141 Ley $\left.N^{0} 18.700\right)$ y los casos de "abandono de funciones".

207 En este sentido Muñoz (1983), p. 478; Peñaranda (1986), p. 123. Otra opinión en Altes (1999), p. 176 quien obviando el nexo propuesto se manifiesta contrario a su tipificación.

208 Peñaranda (1986), p. 1180; Orts (1977), p. 278.

209 Así se explica por qué la formulación debiese también incluir a los actos de coerción ejercidos sobre quienes cumplen funciones de gestión u organización del proceso electoral (incluyendo el escrutinio). En este sentido, GÁlveZ y RuBıo (2007), pp. 122 y 123. También califica esto último como coacción JIMÉNEZ
} 
4. Diverso es el significado de las manifestaciones no violentas (ejecutadas el día de la elección o escrutinio), cuya sanción solo podría justificarse si aparece asociada al quebrantamiento de deberes de prescindencia o abstención o asociada a la regulación de la propaganda electoral ${ }^{210}$.

Se debiera considerar una regulación amplia del quebrantamiento de los deberes de prescindencia o abstención que comprenda la proscripción de toda actuación de autoridad pública que favorezca o beneficie a alguna de las preferencias que se encuentre en competencia (intervencionismo) ${ }^{211}$, además de la sanción de quienes quebranten la neutralidad que impone el ejercicio de funciones electorales que suponen imparcialidad ${ }^{212}$. Hay que tener en cuenta que este tipo de conductas -asociadas a la idea de corrupción electoral-suelen ser las más relevantes; las que en mayor medida provocan efectos sobre los resultados del proceso electoral y sobre la propia institucionalidad del Estado ${ }^{213}$ y, a su vez, las menos tratadas en la regulación ${ }^{214}$.

(1994), p. 68. Una noción diversa se advierte en la conceptualización propuesta por GÁlvez y RuBIO (2007), p. 119, quien entiende por obstaculización cualquier forma de afectación del ejercicio libre del sufragio individual, incluyendo la coacción y el cohecho, sea que se ejerza sobre quienes cumplen funciones organizativas como respecto de los propios votantes (GÁLVEZ y RUBIO (2007), pp. 122 y 123).

210 Al respecto Gálvez y Rubio (2007), p. 28; Polanco (2011), p. 9; Astarloa y Sieira (2016), p. 190; Betanzos (2012), p. 112 y Fuentes y Herrera (2014), p. 31

211 Así, por ejemplo, sobre la realidad en Chile asociada a la inversión pública que se invierte en recursos de publicidad propios del gobierno de turno asociados a procesos electorales, véase ReHEREN (2016), p. 139. Sobre otras formas asociadas a dicha noción véase García e llLaNes (2007), pp. 55 y 57, entre las que destaca el "clientelismo" (García e Illanes (2007), pp. 59 y ss.). Sobre los efectos y dinámicas asociadas en la actualidad al clientelismo político, véase ArRIAGADA (2013), pp. 17 y 18 (destacando los nexos que genera entre quienes ejercen el poder y los dirigentes de base).

212 En la actualidad se considera punible bajo este rótulo la conducta de los funcionarios y de todos aquellos que presten funciones en servicio electoral que militen en partidos políticos, participen o adhieran a reuniones, manifestaciones, asambleas, publicaciones o actos político partidistas o de apoyo a candidatos u opciones en plebiscitos (Ley $N^{\circ}$ 18.556), además de la proscripción de quienes declaren falsamente no estar afiliados a un partido político cuando se asume un cargo incompatible con dicha afiliación (art. 18 Ley $N^{\circ} 18.603$ ).

213 Al respecto, véase García e llLanes (2007), p. 58.

214 Astarloa y Sieira (2016), p. 188; Betanzos (2012), p. 113; Fuentes y Herrera (2014), p. 33; De Urbano (2011), pp. 1 y 2; Muñoz (1983), p. 465; Galeano (2011), p. 554; PeÑaranda (1986), pp. 1194 y 1195 ; RodríGuez (2006), p. 38. La doctrina reconoce razones para favorecer la impunidad. Por un lado, se destaca la dificultad que existe para definir el campo de lo proscrito al margen de la valoración de las intencionalidades, teniendo en cuenta además la necesidad de reconocer espacios a la legítima pretensión de destacar el mérito de lo realizado para solicitar la reelección (sobre esta problemática, véase Ríos (2012), pp. 104 y ss., en relación a la llamada propaganda institucional). Por otro lado, el que las percepciones asociadas a su persecución y sanción suelen encontrarse estrechamente vinculadas a los resultados y favorecidas por un manto de tolerancia generalizado (NIEvA (2013), p. 3). A fin de cuentas, la literatura destaca que la corrupción depende en buena medida de la fortaleza o debilidad 
5. Resulta además necesario incorporar un régimen sancionatorio de carácter amplio para el financiamiento y la propaganda o campaña irregular ${ }^{215}$, tomando como base que son las reglas generales las que definen los límites y formas aplicables a dichos contextos, siendo dichas condiciones las que

de la construcción democrática del pueblo (CRUz (2013), p. 7). En este sentido MuÑoz (1983), p. 461 destaca que la credibilidad y validez del proceso electoral depende de "la realidad material de la democracia" o de lo que denomina como "contexto democrático". Asimismo, véase VilLORIA (2006), pp. 16 y 136. Con ejemplos históricos asociados a la idea del caciquismo, véase De Urbano (2011), pp. 1 y 2. En este mismo sentido se destaca también que los auténticos riesgos no dependen de la realización en actos materiales evidentes, sino que suelen estar vinculados a la actuación encubierta o aparentemente lícita de poderes fácticos, grupos de poder y abusos del poder público. MuÑoz (1983), pp. 472 y 473; ROdRíGUez (2006), p. 40; VILLORIA (2006), p. 11. Lo dicho debiese motivar un régimen especial de tratamiento de la actuación a través de estructuras organizadas (ROMERO (2005), p. 101) con el correspondiente reflejo en el ámbito de la regulación procesal (Altes (1999), p. 184; OLAizOLA (2014), pp. 168 y sS; De LA MATA (2016), pp. 21 y 22), pues estos caracteres decantan en la afirmación de que se trata de irregularidades y delitos "de difícil prueba" (GarCía (2007), p. 23). Sobre las herramientas procesales idóneas, LuZÓN (2015), pp. 243-255, especialmente LuZón (2015), pp. 254 y 255. Esto último se favorece asimismo por el hecho de que constituyen delitos de ejecución "clandestina" (LeHOucQ (2007), pp. 2 y 27; VILLORIA (2006), p. 55) y por el hecho de que su complejidad demanda "macroprocesos" (al respecto, Nieva (2013), pp. 4 y ss.) Sobre otro tipo de medidas a implementar véase García e lLLANES (2007), pp. 79 y ss.

${ }^{215}$ En el mismo sentido, RodríGuez (2006), p. 25. La regulación de la propaganda electoral se basa en la necesidad de asegurar igualdad para los potenciales candidatos y el derecho del elector a emitir su voto de manera informada (ver Informe Final, Consejo Asesor Presidencial CONTRA los Conflictos de INTERÉS, EL TRÁFICO DE INFLUENCIAS Y LA CORRUPCIÓN (2015), p. 72), considerando especialmente el papel determinante que cumple la llamada "campaña electoral" (al respecto, véase PeÑaranda (1986), p. 1189; Muñoz (1983), pp. 470 y 471; Martí y MuÑoz (2008), p. 5; Rodríguez (2006), p. 25; Maroto (2015b), p. 138; ARIÑO (2009), p. 36; Ríos (2012), pp. 93 y ss. y 97 y ss.). Sobre dicho contenido véase JiméNeZ (1994), p. 57. En la actualidad se ha hecho necesario llegar a regular la llamada "precampaña" por diversas razones (al respecto PeÑARANDA (1986), p. 1191; CAMACHO (2015), p. 124), entre las que destaca la dificultad para separar dichos actos de los que son propios de ciertos cargos y partidos (PeñARAndA (1986), p. 1192 y MARTí y MUÑOZ (2008), p. 12). Por su parte la regulación del cese de campañas y su asociación a ciertos deberes de abstención se vinculan a la necesidad de disponer de un "período de reflexión" (Gálvez y RUBıo (2007), p. 27), donde se inscribe los casos de manifestaciones no violentas en el contexto de la elección a los que antes nos referimos. Sobre los problemas que a este respecto propone la tecnología y las redes sociales en la actualidad véase CAMACHO (2015), p. 123; Rodrícuez (2006), p. 25. Sobre el incremento de los costos de la propaganda en la actualidad (y sus efectos criminógenos), véase VILLORIA (2006), pp. 226 y ss.; BLANCO (1995), pp. 175 y ss. Finalmente, se debe tener en cuenta que este es el mismo contexto en el que se desarrolla la regulación de las encuestas asociadas a procesos electorales (por la potencialidad que tienen para incidir en el voto o resultados). Al respecto, por todos, Peñaranda (1986), p. 1200; Martí y MuÑoz (2008), p. 5. Con un contenido equivalente (por el efecto comunicacional que tienen en el prestigio asociado a partidos y candidatos), la regulación española prevé una agravante de pena para los delitos de injuria y calumnia ejecutados con motivo u ocasión de una campaña electoral. Al respecto véase Rodríguez (1995), p. 1240; PeÑaranda (1986), pp. 1235 y ss.; Martí y MuÑoz (2008), pp. 5, 6 y 14; RodríGuez (2006), p. 18, y Jiménez (1994), p. 76 (con una perspectiva más bien crítica). 
operan como garantías objetivas de equidad ${ }^{216}$. Se justifica por ello penalizar toda contravención a las reglas que limitan o regulan ambas materias, sin perjuicio de disponer de válvulas que permitan eximir de pena a los casos que se muestren más insignificantes.

6. Finalmente, se debiera sancionar toda forma de incidir en el falseamiento del acto de patrocinio de una candidatura y en la fijación del domicilio electoral, en la medida que se trate de procesos electorales en que dichas exigencias cumplan alguna función a los efectos de determinar condiciones básicas para elegir o ser elegido ${ }^{217}$.

Con respecto a los demás casos y, en especial, aquellos que se suprimen por razones materiales, procuraremos explicitar en forma algo más detallada las razones tenidas en cuenta respecto de aquellos que en mayor medida pudiesen Ilamar la atención. Destaca en este sentido la impunidad propuesta para la venta de votos, para las conductas que constituyen violación de contenidos reservados, la referida a actos de apropiación, distracción o percepción indebida de bonos o beneficios $y$, finalmente, las formas de falsedad que puedan incidir sobre registros o soportes documentales en general. Con respecto a la venta del voto hemos ya advertido que se trata de una conducta que no altera la igualdad en el ejercicio del derecho de sufragio. Sin embargo, además se debe tener en cuenta que la libertad que supone su ejercicio lleva a considerar legítimo el que se pueda llegar a expresar en base a motivaciones individuales egoístas o particulares que resulten ajenas al interés o bien colectivo, entre

216 En la actualidad solo se sanciona a quienes otorguen u obtengan un aporte para una candidatura o partido político que exceda en 40\% el monto de lo permitido en forma individual o en global (art. 27 bis Ley $N^{0} 19.884$ ), y a quienes otorguen u obtengan aportes de personas jurídicas (art. 27 bis. inc. $2^{\circ}$ Ley $N^{0}$ 19.884). Por su parte toda la regulación sancionatoria asociada a campañas electorales se desarrolla en la actualidad en sede administrativa.

217 En este caso se consideraría la pena actualmente prevista para quien incite, promueva, solicite u organice electores para que modifiquen su domicilio electoral con datos falsos o usando otros diversos a los que se encuentran habilitados (art. 54 Ley $\mathrm{N}^{0}$ 18.556), identificada con la idea de acarreo de votos; para quien proporciona datos falsos o un domicilio electoral diferente a los habilitados al declarar o actualizar domicilio electoral o acreditar avecindamiento (art. 53 Ley $N^{\circ} 18.556$ ) y para quienes suplanten a una persona en una solicitud de cambio de domicilio o avecindamiento u oculta, sustrae o destruye una solicitud de cambio de domicilio, de avecindamiento o sus antecedentes de respaldo (art. 53 Ley $\mathrm{N}^{\circ}$ 18.556). Además, el falso testimonio en el patrocinio de candidaturas independientes (art. 128 de la Ley $N^{\circ}$ 18.700). Hay que tener en cuenta que dicho acto supone que el patrocinante declara que no se encuentra afiliado a un partido político constituido o en formación y que deben tener inscripción vigente en la respectiva circunscripción o distrito (arts. 10 y 11 Ley № 18.700). El doble patrocinio y el hecho de no tener inscripción competente solo reciben sanción de multa administrativa (art. 127 de la Ley $\mathrm{N}^{0}$ 18.700) y es aplicable al notario que autoriza patrocinio sin comparecencia personal (art. 129 de la Ley No 18.700). 
las que se puede considerar el lucro, sea directo o indirecto ${ }^{218}$. De ahí que tampoco se sancione penalmente a quien deja constancia del voto, conducta sancionada desde antiguo como medida de flanqueo respecto de la coacción o el cohecho (orientada a dificultar la acreditación de la preferencia marcada) ${ }^{219}$. En nuestra perspectiva se debe reservar dicha medida para la sede administrativa, reservando la intervención penal solo para aquel que vulnera el secreto del voto respecto de terceros 220

En cuanto a los casos asociados a violación de reserva, se debe tener en cuenta que los datos consignados en el registro o padrón electoral y en los demás que sean relevantes para el desarrollo y control del sistema electoral -incluyendo especialmente los asociados al financiamiento- no solo son públicos, sino que además es deseable que lo sean ${ }^{221}$. Por otro lado, el eventual uso de este tipo de datos -especialmente del padrón o registro- para gestionar contactos irregulares orientados al cohecho o a la coacción, constituirían comportamientos que se inscribirían en el contexto de las fases preliminares de ejecución de dichas conductas, de forma que su sanción debiese quedar entregada a las reglas generales.

Por su parte, la única opción de identificar un contenido relevante tras el apoderamiento irregular de dineros propios de una campaña electoral se podría vincular a la provocación de condiciones desventajosas en comparación con la disposición real de recursos con que contaba la correspondiente opción, mientras que la regulación que las incrimina pareciera más bien concentrarse en exclusiva en la merma o menoscabo económico que su ejecución supone, de forma que no es posible advertir un sentido diverso al que subyace al que ofrece el hurto, la apropiación indebida o la administración desleal, según sea el

${ }^{218}$ Lo dicho se extiende a quien sufraga por dádiva o dinero actualmente incluida en el inc. $2^{\circ}$ del art. 137 de la Ley $N^{\circ} 18.700$.

219 En este sentido, ORTS (1977), p. 276. En la actualidad la sanción de dicha conducta se regula en Chile en base al establecimiento de una presunción (asociada a la venta del voto), contenida en el inc. $2^{\circ}$ del art. 137 de la Ley $N^{\circ} 18.700$, cuyo presupuesto consiste en "dejar constancia de la preferencia por cualquier medio".

220 En derecho comparado prima más bien el criterio opuesto: se penaliza la propia decisión del votante de renunciar a la reserva (por las razones mencionadas) y se declara impune la vulneración que terceros pudiesen realizar sobre el carácter secreto de la emisión del voto. Se exceptúan lugares como México donde se ocupa un criterio equivalente al propuesto en el texto. Sobre ello véase POLANCO (2011), p. 12.

${ }^{221}$ Lo dicho se confirma si tenemos en cuenta que las razones que en la actualidad justifican el carácter reservado de los aportes menores radican en consideraciones pragmáticas asociadas a la dificultad de administrar el registro de donaciones u otras contribuciones en pequeñas cantidades. En este sentido, como indica ChazARRA (2016), p. 74, el objetivo de la mayoría de las regulaciones apunta a sancionar el ocultamiento o falseamiento, y no el financiamiento irregular. 
caso $^{222}$. Lo propio sucede -y por esta misma razón- con quien aplique recursos de una campaña electoral en fines distintos a los que son propios. Por último, la percepción de subsidios asociados al financiamiento público de campañas solo podría ofrecer un contenido idóneo para justificar una incriminación -en relación al desarrollo del proceso electoral- si dicha conducta implicara un acceso en condiciones comparativamente ventajosas, pues la consideración de dichos recursos debiera administrarse con un sentido de equidad a riesgo de generar incidencias indebidas en el proceso electoral ${ }^{223}$. No obstante, no parece que dicho efecto se pueda llegar a advertir en el régimen previsto en la actualidad en nuestro país, teniendo en cuenta que estos aportes están previstos bajo mecanismos que operan a posteriori, una vez que el proceso electoral ha finalizado, y que toman como base los votos efectivamente obtenidos en el correspondiente escrutinio. De esta forma, solo parece relevante el sentido que tendría su ejecución en cuanto fraude de subvenciones sin que sea posible advertir incidencias que tengan relevancia de cara al desarrollo o curso del proceso electoral $^{224}$.

Por último, quisiéramos detallar que las formas de falsedad posibles de identificar carecen de sentido o consideración autónoma. En su caso, constituirán formas de alteración de datos o registros previstos en las reglas previamente anunciadas en cuanto formas o modos de interferir en la regularidad del desarrollo del acto electoral o del escrutinio ${ }^{225}$, o como casos de obstaculización ${ }^{226}$.

222 A este respecto, sobre el papel distintivo que cumple la referencia al lucro individual, véase MARTí y MuÑoz (2008), pp. 15 y 16. En el mismo sentido, sobre la necesidad de diferenciar los casos en que la apropiación tiene fines personales (lucro) de los que no, véase Romero (2005), p. 118.

223 El financiamiento público de campañas electorales constituye uno de los mecanismos con que cuentan los Estados para favorecer la igualdad en la contienda (junto a otros, como la fijación de límites al gasto electoral), y que goza en la actualidad del parecer favorable de las opiniones en general por presentar múltiples ventajas comparativas. Entre ellas se menciona el que permite la representación de ideas que carecen de respaldo económico; reduce la importancia del aporte privado y de los conflictos que ello puede suponer para el posterior ejercicio del cargo y el que se materializa de forma objetiva, entre otras. Al respecto véase Fuentes y HeRreRA (2014), pp. 26 y ss. La obtención indebida de dichos aportes supondría por ello una alteración del marco de igualdad que concede -generalmente parcial-sin que por ello pierda su naturaleza en cuanto percepción indebida de prestaciones públicas, constituyendo una modalidad posible de asimilar al fraude de subvenciones. En este sentido Romero (2005), pp. 152 y 153.

224 En relación a ambos casos, y a su configuración como actos de administración desleal o actos de fraude fiscal o de subvenciones, véase MAroto (2015b), pp. 247 y ss., y 276 y ss., respectivamente.

225 En este sentido Peñaranda (1986), pp. 1144-1146, quien advierte que, por ejemplo, el no dejar la constancia que corresponde en los registros se reconduce a una hipótesis de falsedad electoral en el ordenamiento español (Peñaranda (1986), p. 1131). Asimismo, Romero (2005), p. 118.

226 En este sentido, Peñaranda (1986), pp. 1149 y 1150, por ejemplo, circunscribe a este grupo los casos en que se altera o cambia la hora de funcionamiento de la mesa, pues entiende que dicha con- 
No quisiéramos concluir sin dejar de mencionar que en cuanto a las formas de reaccionar la literatura destaca el uso preventivo que aporta la consideración de sanciones accesorias específicas que buscan radicar la responsabilidad, en esencia, en la conducta de los candidatos o partidos ${ }^{227}$, destacando la inhabilitación para sufragio pasivo ${ }^{228}$, la pérdida del correspondiente escaño ${ }^{229} \mathrm{o}$ la sanción del propio partido político como persona jurídica ${ }^{230}$.

\section{Consecuencias relevantes en el ámbito concursal}

Lo dicho en el párrafo precedente permite advertir que la conceptualización propuesta también aporta contenidos relevantes para clarificar algunas cuestiones complejas que propone el tratamiento concursal asociado a la comisión de este tipo de delitos. Para ello se hace necesario distinguir tres grupos o constelaciones de casos diversos, a saber: Por un lado, aquellos en que la ejecución de la infracción electoral se acompaña de la constatación de un resultado o de una lesión que resulta relevante para la protección de un bien jurídico distinto; aquellos casos en que el modo comisivo a partir del cual se describe un delito electoral satisface por sí mismo, y de forma completa, los supuestos necesarios para configurar otro supuesto incriminado (como sucede con los casos de coacción violenta o en los supuestos de falsificación de registros, padrones o actas de escrutinio); Por último, se deben resolver los casos en que es posible atribuir a un mismo individuo la ejecución de diversas modalidades comisivas desarrolladas en el contexto de un mismo proceso electoral.

Conforme a lo sostenido hasta este momento corresponde a nuestro juicio asignar a los dos primeros supuestos un tratamiento concursal. En el primer caso, dicha conclusión se respalda por la constatación de un elemento o propiedad valorada por el legislador penal que va más allá de aquellas que

ducta busca inducir a error en el elector, pero no alterar la realidad del proceso electoral en sí mismo.

227 Fuentes y HeRrera (2014), p. 32. Sobre la positiva valoración de este tipo de reacciones por sobre otras más tradicionales (como la multa o la privación de libertad), véase VILLORIA (2006), pp. 237 y 238.

228 Este efecto se encuentra previsto en la legislación española y alemana. Al respecto, véase GÁlvEZ y Rubio (2007), p. 115; Cruz (2013), p. 23; RodríGuez (2006), p. 1240; Peñaranda (1986), pp. 1108 y ss.; Martí y Muñoz (2008), pp. 4 y 5; Espín (1997), p. 128. Se puede también consultar su crítica en FARALDO (2014), p. 161, fundada esencialmente en el hecho de que supone la pérdida de un derecho básico de carácter político. Su justificación, a dichos efectos, radica en que se la asocia a la naturaleza concreta del delito cometido (FARALDO (2014), p. 165; JiméNez (1994), pp. 15 y 18).

229 Al respecto, por todos, véase Fuentes y HeRrera (2014), p. 32.

230 De Pablo (2016), pp. 343 y ss. 
se consideran relevantes a efectos de la incriminación del correspondiente delito electoral. Siendo así, la afirmación de un concurso aparente las dejaría al margen de toda consideración vulnerando el principio de exhaustividad ("qua delicta tot poenae $e^{\prime 231}$. Así, quien realiza un aporte de dinero al desarrollo de una campaña electoral más allá del monto permitido, afectará por ese solo hecho la igualdad del proceso electoral debiendo recibir la sanción correspondiente. Si dicho aporte se materializa a través de una falsedad contable -que tiene implicancias tributarias e infraccionales- nada obsta a la configuración del correspondiente concurso. Lo propio sucede si se ofrece una cantidad de dinero al delegado de una junta electoral por adulterar los resultados consignados en las respectivas actas de escrutinio, pues además del correspondiente delito de cohecho concurrirá la correspondiente infracción electoral.

El segundo grupo de casos se debe resolver de forma equivalente y por las mismas razones. La constatación de que el medio comisivo previsto en un delito electoral satisface por sí mismo todos y cada uno de los supuestos de incriminación previstos para un delito distinto, llevará normalmente a identificar un referente o bien jurídico alternativo y diverso que apoya su incriminación. De esta forma, la pretensión de configurar este caso como un supuesto de absorción o consunción dejaría fuera de consideración a una parte de los contenidos que han sido definidos como relevantes por parte del legislador, infringiendo con ello el mismo principio de exhaustividad. Así, por ejemplo, la ejecución de una coacción violenta que condiciona el voto de un determinado elector habilita a aplicar la correspondiente infracción electoral debiendo además estimarse concurrente la respectiva hipótesis de coacción pues, de otra forma, el daño causado sobre la libertad de decisión del correspondiente elector quedaría sin valorar.

Conviene señalar, además, que en este tipo de casos no es posible advertir una relación de especialidad. Ello supondría que una de las figuras en juego comprende la totalidad de los contenidos relevantes para la incriminación, aportando la otra un elemento distintivo ${ }^{232}$. Sin embargo, lo que sucede en estos dos grupos de casos es que todas las figuras concurrentes consideran propiedades que carecen de toda significación en la otra, ofreciendo un modo de relación que resulta incompatible con la constatación de una relación de género a especie. En el ejemplo citado, la lesión de la libertad del votante, como acto individual, es irrelevante en la coacción electoral; mientras que el riesgo

231 Al respecto véase Maldonado (2016), pp. 579-581 y Mañalich (2011), p. 143.

232 EtcheberRy (1997), p. 123. 
asociado a una desigual representación carece por completo de relevancia en el campo de la coacción.

Más complejo es el escenario que propone la ejecución de una pluralidad de hipótesis comisivas en un mismo contexto electoral. De partida, la advertencia de una lesividad en común habilita - de suyo- a considerar que se trata de delitos de la misma especie a los efectos de la aplicación de la regla de reiteración prevista en el artículo 351 del Código Procesal Penal, lo que, en parte, contraviene el sentido natural que subyace a dicha calificación. No hay que olvidar, sin embargo, que se trata de modos de ataque que resultan equivalentes en cuanto formas de afectación del derecho a ejercer el sufragio en condiciones de igualdad. Con ello es perfectamente posible llegar a sostener que el recurso a diversas formas comisivas orientadas a incidir sobre una misma elección, no son más que partes diferenciadas de una misma realización (que se presentan bajo una relación que identificamos comúnmente con la idea de emprendimiento ${ }^{233}$ ), que por ello se corresponde con una única ejecución. Con ello, se debe descartar su calificación como un caso de reiteración.

\section{Delitos electorales y corrupción}

Hemos dejado para el final una cuestión que pudiese parecer marginal, pero que revise un grado de importancia no menor: la posibilidad de considerar a los delitos electorales como formas de corrupción. Advertimos desde las primeras líneas de esta contribución que el desarrollo de este tipo de infracciones suele aparecer vinculado a contextos y actos calificados como formas de corrupción política o pública en general, lo que incide en aproximaciones, interpretaciones y valoraciones sobre sus contenidos particulares. Lo relevante a dicho respecto es tener en cuenta que más allá de los contextos la idea de corrupción no juega ningún papel en la configuración de los delitos electorales pues su estructura propia se vincula al ámbito en que se configura o determina el poder público o político en general, lo que necesariamente tiene lugar antes de que se haya individualizado el campo específico de su ejercicio, previo por ello al contexto en el que se define la idea de corrupción ${ }^{234}$. De esta forma se trata de una noción que solo puede resultar aplicable en una aproximación de

\footnotetext{
233 Al respecto véase en el derecho chileno Politoff et al. (2004), pp. 450 y 451.

234 Se puede consultar una opción diversa en MALEM (2000), p. 27, quien entiende que la consideración pública del acto de corrupción se satisface con el solo hecho de que una de las partes cumpla una función política o pública, entre las que considera actividades materiales (participación en un partido político), funciones de hecho (ser funcionario electo, pero que no ha asumido formalmente el correspondiente cargo) y el propio acto de sufragar. Entiende por ello que la "venta del voto", por ejemplo, es un acto de corrupción política. El nexo con la idea de corrupción se suele afirmar a partir
} 
corte coloquial, como acto decadente, inmoral, erosivo o que provoca efectos corrosivos $^{235}$.

Si bien es indiscutible que la conceptualización de esta noción (corrupción) no es pacífica en derecho penal ${ }^{236}$, basta revisar las conceptualizaciones más estrictas que han sido propuestas en el ámbito del derecho penal para advertir que ninguna resulta aplicable a las conductas que tradicionalmente son catalogadas como delitos electorales. En efecto, la comprensión más tradicional adscribe dicha calificación en torno a la idea de probidad identificando el "acto corrupto" con el abuso funcionario y con diversas modalidades asociadas a la idea de "deslealtad" en el ejercicio de la correspondiente función, lo que la presupone ${ }^{237}$. Otros lo vinculan más bien a la actuación orientada a la obtención de ventajas indebidas mediante dicho ejercicio o con el quebrantamiento de un deber posicional con miras a una ventaja extraposicional238, y

de la constatación de que la ejecución de estos delitos supone una frustración de intereses públicos o generales. Al respecto véase CONTRERAs (2004), pp. 390 y 391.

235 En este sentido Galeano (2011), p. 549, entendiendo que dicha calificación se basa en la comprensión de los delitos electorales como actos que resultan incorrectos en el desarrollo de la contienda electoral. Con respecto al nexo entre dicha noción y una aproximación terminológica al concepto véase Lascano (2007), pp. 91 y 92; De La Mata (2016), p. 4. Asimismo, véase ArTaza (2016), pp. 309 y 310.

236 De la Mata (2016), p. 4. A nivel general, véase, García (2007b), pp. 72 y ss.; Villoria (2006), pp. 26-28; ReHEREN (2016), p. 134, y Mendilow (2012), p. 5, con expresa referencia a las dificultades que supone su conceptualización precisa y a las diversas fórmulas propuestas y sus principales déficits (en Mendilow (2012), pp. 6 y ss.). Destaca un estudio de Gibbons en el que concluye que "el concepto es 'fundamentalmente ambiguo' y que 'podría significar diferentes cosas para según qué individuos'" (p. 7). Ello se explica en parte por el hecho de que se lo reconoce como un concepto de carácter difuso y, además, por el hecho de que "precede al mundo del derecho", habiendo sido abordado principalmente por la sociología y en la ciencia política. Al respecto véase ConTRERAS Alfaro (2004), p. 371 y Villoria (2006), pp. 36-48. Sus orígenes radican en condicionantes sociales, político-estructurales, institucionales e internacionales. Al respecto ConTreras (2004), pp. 374-380 (con detalle sobre sus causas). En un sentido equivalente Balmaceda y CASTRO (2015), pp. 17, 18 y, especialmente, pp. 36 y ss.

237 Al respecto, CaÑIZARES (2016), pp. 17 y ss. La noción genérica de corrupción vinculó históricamente el contenido de dicho término a la infracción de deberes, aproximándolo a la idea de falta de probidad (y la deslealtad) y a comportamientos asociados a estructuras institucionales, paradigmáticamente en torno al sector público. En este sentido se habla de "utilización torcida del poder (...o) desviación de poder y enriquecimiento o beneficio particular", como indica CONTRERAS (2004), pp. 372 y 387 . En un sentido equivalente-como especial forma de afectación centrada en los delitos contra la administración- véase BALMACEDA y CASTRO (2015), pp. 21-24 y 113. Sobre esta tendencia (tradicional), véase Álvarez (2007), pp. 49 y 50. De ahí que sea una definición que se estima como propia de los Ilamados delitos funcionarios. ArTAZA (2016), pp. 311-314; ChAZARRA (2016), pp. 64 y 65. Asimismo, véase también la relación que expone Mendilow (2012), pp. 5 y 6.

238 Por todos, Malem (2000), p. 27. Sobre qué significa Garzón Valdés (2007), pp. 15-18. Sobre ello véase también CaÑIZAREs (2016), pp. 25 y 26. 
otros, por último, lo definen a partir de la existencia de una relación tripartita configurada a partir de un poder de decisión transferido en cuyo ejercicio se genera una ventaja que es contraria a los intereses que la constituyen que beneficia a un tercero ${ }^{239}$.

Se podrá advertir que todas estas definiciones suponen (cuando menos) la existencia de una relación de representación o de poder constituido ${ }^{240}$, lo que confirma su inaplicabilidad sobre conductas que operan precisamente en un ámbito previo a su propia configuración (en este caso, del poder político). Lo dicho se puede constatar con facilidad en buena parte de las figuras paradigmáticas que conforman esta agrupación, como sucede con la compra o venta de votos, con la coacción que se ejecuta sobre uno o más electores para condicionar su preferencia, en la sustracción de efectos dispuestos para el desarrollo de la votación o del escrutinio (incluyendo los votos que constan en la urnas) y con mayor claridad aun en los casos de propaganda extemporánea o financiamiento irregular (que excede los montos declarados y permitidos). Con ello se debe descartar la idea de que su interpretación como actos de corrupción pueda brindar utilidad u ofrecer implicancias concretas en la formulación o interpretación de este tipo de figuras delictivas.

Si bien es posible identificar algunos casos de delitos electorales donde el abuso de poder o el incumplimiento de funciones públicas es considerado a los efectos de determinar modalidades o formas de comisión particulares, también es posible advertir que su consideración específica en cada uno de esos casos no juega un papel estructural o definitorio en el contenido de injusto de las correspondientes infracciones. Así sucede, por ejemplo, respecto del vocal o miembro de mesa receptora que impide votar a quien tiene derecho o que permite la intervención de quien carece del mismo; que oculta, sustrae o destruye el contenido de la urna con votos emitidos que no han sido escrutados o del miembro de un colegio escrutador que falsea los datos del registro que tiene a su cargo. En todos estos casos resulta irrelevante que la interferencia en el ejercicio igualitario del sufragio haya sido provocada a través de una conducta de "privados" (que impiden votar, votan dos veces, sustraen los votos o adulteran el resultado del escrutinio) o en base a una manifestación de poder (como las mencionadas por vía ejemplar), al margen de la consideración que

239 Al respecto KindhäUser (2007), pp. 5-7; ArTAZA (2016), pp. 316-318; asimismo, Mañalich (2015), p. 94. 240 Al respecto véase VILLORIA (2006), p. 54. 
cabe brindar en forma complementaria a dicho abuso o incumplimiento de funciones públicas a efectos de la valoración de su gravedad ${ }^{241}$.

Las únicas figuras o casos en que se puede identificar un aporte esencial o estructural se vinculan a las infracciones que se configuran a partir del quebrantamiento de deberes específicos de abstención de funcionarios, pues en dichos casos el correspondiente abuso materializa en sí mismo una condición de privilegio en la contienda electoral (cuya consideración precisamente opera como fundamento del correspondiente deber quebrantado). Así sucede en el quebrantamiento de la prescindencia electoral que pesa sobre ciertos cargos relevantes -cuyas funciones se vinculan a roles institucionales que requieren de imparcialidad- y con los actos de intervencionismo atribuibles a su desempeño o ejecución ${ }^{242}$, pues lo relevante en ellos radica en que la correspondiente interferencia se obtiene mediante un uso (o abuso, más bien) desviado del poder político para fines de perpetuarse ${ }^{243}$. El que solo en dichos casos se pueda identificar comisiva propia de un acto de corrupción, no hace más que confirmar su carácter excepcional en el contexto de los delitos electorales, lo que ratifica lo que antes hemos señalado. Constituyen por ello solo formas o modos de ejecución alternativos, entre muchos otros posibles de considerar. Es esta misma consideración la que explica por qué ameritan una asignación de particular gravedad según hemos tenido oportunidad de sostener.

Ahora bien, el que las conductas incriminadas bajo este rótulo no constituyan per se formas de corrupción en cuanto delitos electorales, nada dice respecto a la eventualidad de que su ejecución pueda llegar a ser constitutiva de una forma o modalidad de corrupción punible, en términos

241 En el sentido indicado Peñaranda (1986), p. 1172 y Polanco (2011), p. 18. No se trata por ello de desconocer la mayor relevancia que tienen el abuso o el incumplimiento de funciones asociadas a la organización y el control y supervisión del proceso electoral (de su preparación, del escrutinio o de la calificación de las correspondientes elecciones), sino solo de advertir que el contenido que ofrecen a efectos de su proscripción penal no es más que el propio de una condición de mayor gravedad, sin que por ello aporte a efectos de condicionar la sustancia la correspondiente infracción.

242 Resulta discutible la consideración en este mismo nivel de aquellos supuestos en los que un candidato que goza de investidura formal -que pretende la reelección- incurre en supuestos delictivos electorales de carácter común, al margen de los efectos atribuibles al abuso de la función pública posibles de reconocer en el campo de las modificaciones de su responsabilidad penal.

243 En este sentido Astarloa y Sieira (2016), p. 188; Betanzos (2012), p. 113; Fuentes y Herrera (2014), p. 33; De Urbano (2011), pp. 1 y 2; Muñoz (1983), p. 465; Galeano (2011), p. 554 con otra cita de ejemplos relevantes (manejar el padrón, ubicar centros de voto lejos del acceso de los electores; abuso de encuestas, etc.), que evidencian la dificultad de asumir su descripción con la precisión requerida. Como señala PeÑaranda (1986), pp. 1194 y 1195, tras dichas actuaciones "es el propio Estado el que se compromete políticamente", de forma que lo que está en juego no es solo el quebrantamiento de un deber, sino la neutralidad de la autoridad. Asimismo, véase Rodrícuez (2006), p. 38 
que permitan identificar razones diversas para fundar una incriminación. Así, quien, por ejemplo, financia a un determinado candidato al margen de las exigencias y límites legales con el objeto explícito de incidir en la forma como se lleve a cabo el respectivo cargo o función, podrá llegar a ser condenado por el respectivo acto de corrupción (en específico, como cohecho o soborno) con total independencia de los efectos que dicha modalidad produce en el desarrollo del proceso electoral ${ }^{244}$. El que las finalidades, motivaciones o efectos que orientan su ejecución resulten del todo ajenas a la estructura de injusto del correspondiente delito electoral, no hace más que ratificar que se trata de hipótesis que deben ser tratadas bajo la correspondiente cláusula concursal, debiendo descartarse la posibilidad de advertir un concurso aparente ${ }^{245}$.

${ }^{244}$ En algunos casos resulta discutible la punibilidad de estos últimos supuestos pues las formulaciones típicas tradicionales asociadas a la corrupción suelen requerir -implícita o explícitamenteque la ejecución de las conductas delictivas tengan lugar en forma coetánea al ejercicio abusivo o distorsionado (ajeno a sus fines propios) del poder político representativo, de forma que presuponen el agotamiento de los procesos destinados a su configuración formal (que es el ámbito de incidencia propio de los delitos electorales). Los casos en que ello no es así -tratados comúnmente bajo la denominación del cohecho político- consideran por ello una extensión o relajación de dicha exigencia. Al respecto, véase, por todos, GuZmán (2017), pp. 185 y ss. Este mismo tipo de problemáticas se advierte en el tratamiento y regulación de la financiación de los partidos políticos pues lo protegido en dicho contexto es su función en el régimen democrático y su incidencia en el ejercicio regular de la función pública. En este sentido Maroto (2015a), p. 761; asimismo, MarOto (2015b), pp. 193 y ss. En la misma línea Olaizola (2014), pp. 137, 139, 173, 191 y 192; Romero (2005), p. 117; ARIÑO (2009), p. 10 (y, con respecto a las discusiones relativas a exigencias de "independencia" que se les pueden demandar, en pp. 21 y ss.); Del CASTILlo (1993), pp. 54-56; Álvarez (1993), p. 14; ArGANDOÑa (2001), p. 2. Lo dicho es particularmente relevante teniendo en cuenta que en algunos casos (conforme al régimen de Gobierno de que se trate), la representación popular se ejerce y formaliza a través de los partidos, en especial tratándose de regímenes parlamentarios. Olaizola (2014), pp. 178 y 179. Esta y otras razones han llevado a que el tratamiento de los delitos asociados al financiamiento electoral y los referidos al financiamiento de la actividad política en general y de partidos políticos se trate en forma conjunta. Sobre ello véase MAroto (2015a), p. 758. Ello obliga a sostener criterios distintivos para diferenciar los fondos electorales de los demás fondos ordinarios, asociados al tipo o destino de los fondos o la forma de recaudación, existiendo zonas grises difíciles de matizar. Sobre ello Olaizola (2014), p. 179; Romero (2005), pp. 80 y ss. Asimismo, también debemos destacar que ambos tipos de ingresos -y gastos- están estrechamente vinculados pues los fondos ordinarios también sirven para ejercer la representación popular y son utilizados, al menos en parte, en las campañas. En Chile, por ejemplo, la regulación autoriza la asignación de un monto de los gastos del partido en la campaña, distribuido proporcionalmente entre todos los candidatos del partido de que se trate. Lo destaca CAMACHO (2015), p. 126. Sobre todo ello véase Astarloa y SieIRA (2016), p. 211. Véase asimismo sobre la regulación de la financiación electoral y de partidos en Chile, CamaCho (2015), pp. 120 y 121.

245 Todo lo dicho en este apartado en torno a la noción de corrupción se replica íntegramente sobre el concepto de fraude o de defraudación, noción que se apoya en la eventual incidencia que tiene en los resultados del proceso y sobre las expectativas legítimas de quienes participan o intervienen 


\section{BiBLIOGRAFÍA CITADA}

Altes Martí, Miguel Ángel (1999): "El delito electoral", en: Corts. Anuario de Derecho Parlamentario ( $\mathrm{N}^{\circ}$ 8), pp. 163-185.

Álvarez Conde, Enrique (1993): "Algunas propuestas sobre la financiación de los partidos políticos", en: Cuadernos y Debates ( $N^{0} 47$ ), pp. 13-36.

Álvarez Medina, Silvina (2007): "Corrupción y corrección políticas", en: Zapatero, Virgilio (Comp.), La corrupción (México, Ediciones Coyacán), pp. 39-64.

Argandoña Ramiz, Antonio (2001): "La financiación de los partidos políticos y la corrupción en las empresas", en: Papeles de Ética ( $N^{\circ}$ 6), pp. 1-20.

AriÑo Ortiz, Gaspar (2009): La financiación de los partidos políticos (Madrid, Cinca).

Arriagada Oyarzún, Evelyn (2013): "Clientelismo político y participación local", en: Polis, Revista Latinoamericana (Vol. 12, № 36), pp. 15-38.

Artaza Varela, Osvaldo (2016): "La utilidad del concepto de corrupción de cara a la delimitación de la conducta típica en el delito de cohecho", en: Revista Política Criminal (Vol. 11, No 21), pp. 307-339.

Astarloa Huarte-Mendicoa, Ignacio y Sieira Mucientes, Sara (2016): "El control electoral de los partidos políticos", en: Matia, Francisco (Dir.), Problemas actuales sobre el control de los partidos políticos (Valencia, Edit. Tirant lo Blanch), pp. 134-215.

Balmaceda Hoyos, Gustavo y Castro Cuenca, Carlos (2015): Corrupción y delitos contra la Administración Pública (Santiago, Librotecnia).

Betanzos Torres, Eber (2012): "Delitos electorales y procuración de justicia penal electoral", en: Revista Justicia Electoral (Vol. 1, No 10), pp. 91-126.

Blanco Valdés, Roberto (1993): "Consideraciones sobre la necesaria reforma del sistema español de financiación de los partidos políticos", en: Cuadernos y Debates ( $\left.N^{\circ} 47\right)$, pp. 37-52.

(1995): "La problemática de la financiación de los partidos políticos en España: regulación jurídica y propuestas de reforma", en: Revista de Estudios Políticos (No 87), pp. 163-197.

Borx Palop, Andrés (2014): "Modelos de financiamiento de partidos políticos y corrupción: de los partidos del sistema a los partidos de los ciudadanos", en:

en ellos. Sobre dicha noción -en términos coloquiales y en Derecho penal- véase MerA (2001), pp. 85-88. Desde esta perspectiva -diversa a la que sostenemos en el texto- ha sido considerada útil para dar cuenta del sentido incriminatorio de este grupo de delitos. Al respecto, véase GaLEANO (2011), p. 553; Gálvez y Rubio (2007), p. 125; LehoucQ (2007), p. 3. 
Jareño, Ángeles (Dir.), Corrupción Pública: Cuestiones de Política Criminal (I) (Madrid, lustel), pp. 161-195.

Bravo Aguilar, Nauhcatzin y Leal Moya, Leticia (2011): "Las salvaguardas de la democracia en materia penal", en: Letras Jurídicas, Guadalajara ( $\left.N^{0} 12\right)$, pp. 1-201.

Camacho Cepeda, Gladys (2015): "Financiamiento de los procesos electorales. Examen de la Ley $N^{0} 19.884$ sobre transparencia, límite y control del gasto electoral", en: Revista de Derecho (Vol. XXVIII), pp. 117-144.

Cambronero Torres, Andrei (2016): "Reflexiones sobre algunos contenidos de la justicia penal electoral costarricense", en: Revista de Estudios de la Justicia (No 24), pp. 45-72.

Cañizares Navarro, Juan Benito (2016): "La corrupción política en España: contribución a su delimitación conceptual (siglos XIX y XX)", en: López y García (Coords.), La corrupción política en España: Una visión ética y jurídica (Madrid, Thomson Reuters Aranzadi), pp. 13-33.

Cobo del Rosal, Manuel (2005): Derecho penal español, Parte especial, $2^{\text {a }}$ edición (Madrid, Dykinson).

Consejo Asesor Presidencial contra los conflictos de interés, el trÁfico de influencias Y LA CORRUPCIÓN (2015): "Informe Final". Disponible en: http://www.minsegpres.gob.cl/wp-content/uploads/2017/04/Informe-del-Consejo-AsesorPresidencial-Contra-los-Conflictos-de-Intereses-el-trafico-de-Influencias-laCorrupcion.pdf [visitado el 8/03/2018].

Contreras Alfaro, Luis Humberto (2004): Los delitos económicos relacionados con la corrupción (Santiago, Editorial La Aurora).

Corcoy Bidásolo, Mirentxu (1999): Delitos de peligro y protección de bienes jurídico-penales supraindividuales (Valencia, Tirant lo Blanch).

Cruz Blanca, María José (2013): "La protección penal del derecho a sufragio. Los delitos electorales", en: Revista Electrónica de Ciencia Penal y Criminología (Vol. 15), pp. 1-27.

Cury Urzúa, Enrique (2007): Derecho Penal. Parte General (Santiago, Ed. Universidad Católica de Chile).

Chazarra Quinto, María Asunción (2016): “El delito de financiación ilegal de partidos políticos: un hito más en la corrupción política y su tratamiento jurídico-penal", en: López y García (Coords.), La corrupción política en España: Una visión ética y jurídica (Madrid, Edit. Thomson Reuters Aranzadi), pp. 63-80. 
De la Mata Barranco, Norberto (2004): La respuesta a la corrupción pública. Tratamiento penal de la conducta de los particulares que contribuyen a ella (Granada, Comares).

(2016): "La lucha contra la corrupción política", en: Revista Electrónica de Ciencia Penal y Criminología (Vol. 18), pp. 1-25.

De Pablo Serrano, Alejandro (2016): "La responsabilidad penal de los partidos políticos: delitos, penas y compliance programms", en: Matia, J. (Dir.), Problemas actuales sobre el control de los partidos políticos (Valencia, Tirant lo Blanch), pp. 330-374.

De Urbano Castrillo, Eduardo (2011): "Los delitos electorales, tras la reforma de 28 de enero de 2011", en: Revista Aranzadi Doctrinal ( $N^{\circ} 1$ 1), pp. 41-49.

Del Castillo Vera, María (1993): "Objetivos para una reforma de la legislación sobre financiación de los partidos políticos", en: Cuadernos y Debates (Vol. 47), pp. 53-64.

Díaz y García Conlledo, Miguel (2007): "El Derecho Penal ante la corrupción política y administratva", en: Zapatero, Virgilio (Comp.), La corrupción (México, Ediciones Coyacán), pp. 115-170.

Dopico Gómez-Aller, Jacobo (2015): “Aproximación a las necesidades de reforma legal en relación con la respuesta penal a la corrupción política", en: Cuadernos Penales José María Lidón (№ 11), pp. 257-284.

Doval PaIs, Antonio (2014): "Delitos de corrupción Pública: Indultos y Condenas", en: Jareño, Angeles (Dir.), Corrupción Pública: Cuestiones de Política Criminal (I) (Madrid, lustel), pp. 41-62.

Esparza Martínez, Bernardino (2014): Delitos electorales. 1812-2014 (México, Instituto Nacional de Ciencias Penales).

Espín Templado, Eduardo (1997): “Una reflexión sobre la representación política y los sistemas electorales en las democracias constitucionales", en: RuizRico, Gerardo y Gambino, Silvio (Coords.), Formas de gobierno y sistemas electorales (Valencia, Tirant lo Blanch), pp. 27-41.

EspinOZA TORReS, María (2000): “Los delitos electorales y la reforma política mexicana", en: Letras Jurídicas. Revista Multidisciplinar del Centro de Estudios sobre Derecho, Globalización y Seguridad de la Universidad de Veracruz (Vol. 2), pp. 111-134.

Etcheberry Orthusteguy, Alfredo (1997): Derecho Penal, $3^{\text {a }}$ edición revisada y actualizada (Santiago, Editorial Jurídica de Chile). 
Faraldo Cabana, Patricia (2012): "Los Delitos Electorales", en: Brandariz, García (Coord.), Comentarios a la legislación penal especial (Madrid, Lex Nova y Thomson Reuters), pp. 175-281.

(2014): "La privación del derecho sufragio pasivo por delito electoral", en: Revista Española de Derecho Constitucional (No 101), pp. 159-179.

Fernández HeRnÁndez, Antonio (2008): Ley de partidos políticos y Derecho penal (Valencia, Tirant lo Blanch).

Fernández SeGado, Francisco y Ojesto Martínez, José (2007): “Delitos y faltas electorales", en: AA.VV., Tratado de Derecho electoral comparado de América Latina, 2a edición (México, ediciones IIDH), pp. 1020-1071.

Fuentes Saavedra, Claudio y Herrera Muñoz, Mario (2014): Financiamiento de la Política. Análisis comparado y propuestas de política, en: Instituto de Investigación en Ciencias Sociales. Disponible en: http://www.icso.cl/wpcontent/uploads/2014/12/Financiamiento-de-la-politica-2.pdf [visitado el 8/03/2018].

Galeano Rey, Juan (2011): "Delitos electorales", en: Castro, Carlos (Coord.), Manual de Derecho penal. Parte especial (Bogotá, Temis), Tomo 2, pp. 538-559.

Gálvez Muñoz, Luis y Rubıo Lara, Pedro (2007): "El régimen de votación de las personas especialmente vulnerables y sus garantías, en particular la penal", en: Anales de Derecho, Universidad de Murcia (No 25), pp. 97-131.

García García, José e Illanes Guzmán, Ignacio (2007): "Intervención electoral y garantías electorales", en: AA.VV., Modernización del régimen electoral chileno (Santiago, PNUD, CEP, Libertad y Desarrollo, Proyactamerica, Cieplan), pp. 55-89.

García Navarro, Juan (2016): "La doctrina social de la Iglesia y la necesaria regeneración ética de los partidos políticos en España", en: López, Antonio y García, Juan (Coords.), La corrupción política en España: Una visión ética y jurídica (Madrid, Thomson Reuters Aranzadi), pp. 111-131.

García Rodríguez, Juan (2007a): "Hacia una participación electoral de mayor calidad", en: AA.VV., Modernización del régimen electoral chileno (Santiago, PNUD, CEP, Libertad y Desarrollo, Proyactamerica, Cieplan), pp. 13-24.

García Viñuela, Enrique (2007b): "La regulación del dinero político", en: Revista Reis ( $\left.\mathrm{N}^{\mathrm{O}} 118\right)$, pp. 65-95.

Garzón Valdés, Ernesto (2007): "El concepto de corrupción", en Zapatero, Virgilio (Comp.), La corrupción (México, Ediciones Coyacán), pp. 11-37. 
Guichot Reina, Emilio (2014): "La nueva regulación legal de la transparencia, el acceso a la información pública y el buen gobierno como mecanismo de lucha contra la corrupción y regeneración democrática", en: Jareño, Ángeles (Dir.), Corrupción Pública: Cuestiones de Política Criminal (I) (Madrid, lustel), pp. 215-238.

Guzmán Dálbora, José (2017): Colectánea criminal. Estampas de la parte especial del Derecho penal (Montevideo / Buenos Aires, BdeF), pp. 163-202.

Hernández Basualto, Héctor (2016): "Sobre la legitimidad de los delitos de peligro abstracto, a propósito de la Jurisprudencia del Tribunal Constitucional chileno", en: AA.VV., El Derecho Penal como teoría y como práctica. Libro en Homenaje a Alfredo Etcheberry Orthusteguy (Santiago, Thomson Reuters La Ley), pp. 149-188.

Jiménez Díaz, María (1994): "Delitos electorales. Su configuración según la Ley Orgánica 5/1985, de 19 de junio", en: Сово, M. у BАјO, M., Comentarios a la legislación penal. Delitos electorales (Madrid, Reus), Tomo 16, pp. 1-85.

KINDHÄUSER, Urs (2007): "Presupuestos de la corrupción punible en el Estado, la economía y la sociedad. Los delitos de corrupción en el Código Penal alemán", en: Revista Política Criminal (№ 3), pp. 1-19.

LASCANO, Carlos (2007): "Funcionarios públicos corruptos, empresarios corruptores y derecho Penal", en: Zapatero, Virgilio (Comp.), La corrupción (México, Ediciones Coyacán), pp. 87-114.

LeohucQ, Fabrice E. (2007): “QQué es el fraude electoral? Su naturaleza, sus causas y consecuencias", en: Revista Mexicana de Sociología (Año 69, $\mathrm{N}^{\mathrm{o}} 1$ ), pp. 1-38.

LuZÓN CÁnovas, Alejandro (2015): "Instrumentos para la investigación de la corrupción", en: Cuadernos Penales José María Lidón (№ 11), pp. 236-255.

Maldonado Fuentes, Francisco (2016): "Reiteración y concurso de delitos. Consideraciones sobre el artículo 351 del Código procesal Penal", en: AA.VV., El Derecho Penal como teoría y como práctica. Libro en Homenaje a Alfredo Etcheberry Orthusteguy (Santiago, Thomson Reuters La Ley), pp. 549-607.

Malem SeÑA, Jorge (2000): "La corrupción política", en: Jueces para la Democracia (No 37), pp. 26-34.

(2007): "Corrupción, racionalidad y educación moral", en: Zapatero, Virgilio (Comp.), La corrupción (México, Ediciones Coyacán), pp. 171-176. Mañalich RafFo, Juan Pablo (2011): "El principio ne bis in ídem en el derecho penal chileno", en: Revista de Estudios de la Justicia, REJ (№ 15), pp. 139-169. 
(2015): “La negociación incompatible como delito de corrupción: estructura típica y criterios de imputación", en: Revista de Estudios de la Justicia ( $\left.\mathrm{N}^{\circ} 23\right)$, pp. 93-105.

Maroto Calatayud, Manuel (2015a): "Financiación ilegal de partidos políticos", en: Quintero, Gonzalo (Dir.), Comentarios a la reforma penal de 2015. Parte especial (Madrid, Aranzadi), pp. 755-768.

(2015b): Financiación ilegal de partidos políticos, un análisis políticocriminal (Barcelona, Marcial Pons).

Martí, Vicente y Muñoz Cuesta, Javier (2008): "Delitos electorales", en: Diario La Ley ( $\mathrm{N}^{\circ}$ 6887), pp. 1-17.

MendiLow, Jonathan (2012): "Corrupción y financiación electoral: una perspectiva Burkeana", en: Eunomía. Revista en Cultura de la Legalidad ( $\left.\mathrm{N}^{\circ} 2\right)$, pp. 3-16.

Mera Figueroa, Jorge (2001): Fraude civil y penal. El delito de entrega fraudulenta (Santiago, LexisNexis).

Muñoz Conde, Francisco (1983): "Delitos electorales", en: AA.VV., Comentarios a la legislación penal (Madrid, Reus), pp. 459-481.

(2015): Derecho Penal. Parte especial, 20ª edición (Valencia, Tirant lo Blanch).

MuÑoz, Jordi (2013): “El precio electoral de la corrupción: ipor qué los votantes la castigan tan poco?", en: Revista Pasajes ( $\left.\mathrm{N}^{\circ} 42\right)$, pp. 22-31.

Nieva FenolL, Jordi (2013): "Proceso penal y delitos de corrupción", en: Revista InDret ( $\left.\mathrm{N}^{\circ} 2\right)$, pp. 1-22.

Nogueira Alcalá, Humberto (2012): Derecho Constitucional chileno (Santiago, Thomson Reuters).

Olaizola Nogales, Inés (2014): La financiación ilegal de partidos políticos (Valencia, Tirant lo Blanch).

(2015): “La respuesta penal ante la corrupción: una aproximación a las principales carencias", en: Cuadernos Penales José María Lidón (№ 11), pp. 183-202.

Oliver Calderón, Guillermo (2013): “La exasperación de la pena en el concurso material de delitos: La reiteración de delitos de la misma especie", en: Revista de Derecho de la Universidad Austral de Valdivia (Vol. 26, № 2), pp. 167-188.

Ortega Forner, Claudia (2007): "Legislación electoral y sanción penal", en: Boletín Delitos Funcionarios del Ministerio Público (№ 5), pp. 30-38. 
Ortega Giménez, Alfonso (2016): "La lucha contra la corrupción política en la Unión Europea", en: López, Antonio y García, Juan (Coords.), La corrupción política en España: Una visión ética y jurídica (Madrid, Thomson Reuters Aranzadi), pp. 51-62.

Orts Berenguer, Enrique (1977): "Consideraciones críticas en torno a los tipos penales del Real Decreto-Ley 20/1977, de 18 de marzo, sobre normas electorales", en: Cuadernos de Política Criminal (No 3), pp. 271-287.

PALDA, Filip (1999): "Regulación del financiamiento electoral en Chile: Lecciones de Canadá y Estados Unidos", en: Revista Estudios Públicos, Centro de Estudios Públicos (No 74), pp. 169-226.

Patiño Camarena, Javier (2012): "El sistema federal y los delitos electorales, Cuadernos para el Debate $N^{\circ} 2^{\prime \prime}$, en: Instituto Federal Electoral. Disponible en: http://portalanterior.ine.mx/docs/IFE-v2/DECEYEC/DECEYECMaterialesLectura/docs/02_SistemaFederalYDelElect.pdf [visitado el 8.03.2018].

Peñaranda, José (1986): "Delitos e infracciones electorales", en: Cazorla, Luis (Dir.), Comentarios a la Ley Orgánica del Régimen Electoral General (Madrid, Civitas), pp. 1097-1238.

PIÑEIRO, Rafael (2008): "Sistemas electorales y corrupción, entre el estímulo y la disuasión", en: Revista de Ciencia Política (Vol. 28, № 2), pp. 187-194.

Polanco Braga, Elías (2011): "Derecho Penal electoral", en: Congreso Iberoamericano Derecho Electoral. Disponible en http://derecho.posgrado. unam.mx/congresos/congreibero/ponencias/EliasPolancoBraga.pdf [visitado el 8.03.2018].

Politoff Lifschitz, Sergio et al. (2004): Lecciones de Derecho penal chileno. Parte General (Santiago, Editorial Jurídica de Chile).

Reheren, Alfredo (2016): "Clientelismo Político, Corrupción y reforma del Estado en Chile", en: Centro de Estudios Públicos. Disponible en: https://cepchile. cl/capitulo-2-clientelismo-politico-corrupcion-y-reforma-del-estado-en/ cep/2016-03-04/093611.html [visitado el 8/03/2018].

Ríos VeGA, Luis Efrén (2012): "Libertad de expresión, equidad y fraude a la ley electoral", en: Revista del Instituto de Ciencias jurídicas de Puebla (Año 6, No 30), pp. 84-117.

Rodríguez Devesa, José María (1995): Derecho Penal Español. Parte especial, $18^{\mathrm{a}}$ edición (Madrid, Dykinson).

Rodríguez Rodríguez, Manuel (2006): "Análisis jurisprudencial del delito de propaganda electoral" en: Revista General de Derecho Penal ( $N^{\circ}$ 6). 
Romero Flores, Beatriz (2005): Partidos políticos y responsabilidad penal. La financiación electoral irregular (Barcelona, Atelier).

Rubio Lara, Pedro y Gálvez Muñoz, Luis (2013): "Delitos en la jornada electoral", en: Revista de Derecho y Proceso Penal (Nº 31), pp. 93-114.

Torres FigueroA, Angélica (2016): “Los tipos penales creados por la Ley No 20.900 para el fortalecimiento de la democracia. Ofrecimiento, otorgamiento, solicitud y obtención indebida de aportes electorales; destinación indebida de aportes electorales estatales; entrega de antecedentes o certificación de hechos falsos al Servicio Electoral", en: Revista Jurídica del Ministerio Público ( $\left.\mathrm{N}^{\circ} 68\right)$, pp. 25-53.

VILLORIA M., Manuel (2006): La corrupción política (Madrid, Editorial Síntesis).

ZúNIIGA, Francisco (2009): “Derecho a sufragio: La debatida cuestión de su obligatoriedad", en: Revista Estudios Constitucionales (Año 7, № 1), pp. 361-384. 